\title{
2. Bilder av och för Birgittasystrar
}

\section{En avgränsad bildvärld}

Nunnorna i Vadstena kloster levde inom ett i högsta grad fysiskt avgränsat område, som i alla nunnekloster. Nunneläktarens avskilda och originella placering mitt i klosterkyrkan kan till och med ses som en betoning av klausuren. Den gjorde dem på en gång avgränsade och upphöjda från omvärlden, samtidigt som den gav dem en central position både rent konkret och idémässigt. Läktarplaceringen gjorde nunnornas sång hörbar för alla i kyrkan, samtidigt som de var osynliga ${ }^{149}$ Att de inte kunde ses av utomstående betydde emellertid inte att de inte kunde se något. Ovan nämndes att de kunde rikta blicken mot altarna i både öster och väster, men även inom läktarens avgränsade område fanns en hel del att vila ögonen på. Heliga Birgittas restriktioner mot dekorativa utsmyckningar i kyrkan tillät visuell gestaltning anpassad till systrarnas andliga behov, precis som i andra nunnekloster. Frågan är i vilken mån vi kan återskapa något av hur den sedan flera århundraden försvunna nunneläktaren var utformad och inredd, och därigenom också försöka förstå bildernas syfte och hur de var tänkta att användas av systrarna.

Hur såg den bildvärld ut som nunnorna omgavs av på läktaren? I vilken mån var denna bildvärld specifikt utformad för dem, och i vilken mån var den gemensam med de andra kyrkobesökarna? Klosterregeln och nunnornas sedvanebok, Lucidarium, ${ }^{150}$ ger viss information, medan bland annat avlatsbrev och bevarade föremål ger oss glimtar från deras forna bildvärld. Texterna i avlatsbreven talar ofta om vad man ska göra i vissa situationer och ger därför värdefull information om hur bilderna var tänkta att brukas. Många populära senmedeltida motiv var dessutom starkt förknippade med vissa andliga aktiviteter. En del av de andliga övningarna framgår även av bönböckerna. Ett sätt att komma nära nunnorna och deras bildsfär är därför att

149 För ljudrekonstruktion se artikel av H. Autio, M. Barbagallo, C. Ask mf "Historically based room acoustic analysis and auralization of a church in the 1470s", Applied sciences 11, February 2021.

150 Lucidarium gavs ut av Gustaf Edvard Klemming redan på 1880-talet men ingen senare edition har ännu publicerats. Se Heliga Birgittas Uppenbarelser, efter gamla handskrifter, utgifna af G.E. Klemming. Samlingar utgivna av Svenska fornskriftsällskapet. Serie 1, Svenska skrifter 14:1-5, Stockholm 1857-1884, band 5 innehåller Lucidarium och gavs ut 1883-1884. 
börja med att studera deras olika böcker. Böckerna var handskrivna och nästan uteslutande tillverkade i klostret av nunnorna själva. De bestod främst av bönböcker, liturgiska böcker och uppbyggelseläsning avsedda att brukas av nunnorna. Genom att undersöka handskrifterna kodikologiskt utifrån tillverkningsperspektivet i skriptoriet, är tanken att öka förståelsen av böckernas utformning och funktion. Därefter diskuteras bildinnehållet: Vad var det som nunnorna valde att framställa visuellt i sina bönböcker? Vilka motiv förekommer? Vid vilka textavsnitt placerades bilderna? Hur kan man tänka sig att de använde dessa bilder? I detta sammanhang är det inte bara de figurativa framställningarna som är relevanta att identifiera. Det är också värdefullt att ta i beaktande den ornamentik som de prydde sina alster med. Ornamentiken vid en text kan ha en fördjupande och/eller associativ funktion för den bedjande/läsande. Detta bokbetraktelsesätt kan även tillämpas på de textila föremål som nunnorna tillverkade. En teknik- och materialundersökning av textilierna kan i likhet med den kodikologiska handskriftsundersökningen ge mer information än en enbart ikonografisk analys. På så vis kan det materiella ge information om det immateriella, dvs. om bruket av föremålen.

Miljön uppe på nunneläktaren var knappast bildfattig, men för den enskilda nunnan var kanske de bilder viktigast som hon hade närmast sig under tidebönerna eller mässan, dvs. de som fanns i bönböckerna. En del av böckerna låg framför henne under tidebönerna och andra bar hon med sig i processionerna. I processionerna kunde systrarna även bära med sig ljus, kors och relikvarier, dvs. föremål som de således flyttade mellan kyrkan, sakristian och klosterbyggnaderna. Enligt klosterregeln skulle nunneläktaren också vara utrustad med ett andaktsaltare på vilket en monstrans var uppställd. ${ }^{151}$ Där fanns också en Mariabild som bars med i en del av processionerna. Genom dessa föremål ökade bildframställningarna genast, och det fanns förmodligen mer. I det följande kapitlet diskuteras därför gestaltningen av nunnornas läktare som helhet, men med början i utformningen av de handskrifter som de själva tillverkade och använde.

\section{Bokproduktionen i klostret}

Oc hwar een syster haffui siin psaltara ypnan fore sik, at ey warde maärkelikin willa ällir oliwdh j chorenom, Alla de systra som sionga j chorenom skul haffua siin öghon oc akt til notonar oc sangin oc til bökrena $j$ bwilkom de sionga, thy at the skulu altidh sionga $j$ bokomen oc enkannelika the wngo. ${ }^{152}$

Citatet ovan ur Lucidarium, sedvaneboken som kompletterade klosterregeln för systrarna, visar att de alla, och särskilt de unga, dvs. ovana/nya, förutsattes ha tillgång till böcker att sjunga och läsa ur, så att de inte gjorde störande oljud (oliwdh) i koret. Med tanke på att det under 1400-talet i stort sett hela tiden var fullt hus i klostret med sextio nunnor, innebär det att det måste ha varit gott om bönböcker att

151 Revelationes Extra. kap. 37. Lundén bd IV 1959 s 141.

152 Klemming 1883-84 s 65-66. 
tillgå och att man behövde ha en kontinuerlig produktion. Idag finns det kvar ca 165 illuminerade Vadstenahandskrifter, varav merparten är från nunnornas konvent. ${ }^{153}$

Böckerna var skapade utifrån användningsområde/funktion. En del var avsedda för enskilt bruk, andra för den gemensamma liturgin. Bland de illuminerade handskrifterna från Vadstenasystrarna finns drygt tjugo bevarade Cantus sororum, fyra psalterier, några så kallade directorium chorii samt cirka tjugo andra bön- och tideböcker. ${ }^{154}$ Nunnornas psalterier och andra liturgiska böcker har ibland påkostade initialer i guld, silver och olika färger, men inga figurativa utsmyckningar. ${ }^{155} \mathrm{De}$ bönböcker som har försetts med miniatyrer eller andra figurativa framställningar är inte de som innehåller systrarnas tidegärd, Cantus sororum, utan är andra varianter av bönböcker. Nunnornas bevarade andaktsböcker förvaras huvudsakligen på Kungliga biblioteket (KB) i Stockholm (ingår i A-samlingen) och i Uppsala universitetsbibliotek (UUB, de ingår i C-samlingen). ${ }^{156}$ Dessa böcker förvarades hos och brukades av nunnorna ända fram till stängningen 1595. Enstaka böcker följde även med några av de sista nunnorna till Gdansk 1596. ${ }^{157}$ Till skillnad från brödernas ursprungligen mycket omfattande bibliotek hölls den mindre boksamlingen hos nunnorna troligen huvudsakligen intakt under reformationsårhundradet, eftersom nunnorna var kvar. 1557 drabbades klostret emellertid av ett inbrott, då sextiofyra böcker stals. Abbedissans klagoskrivelse till kungen anger inte explicit från vilken del av klostret böckerna blev stulna, men engagemanget för böckerna skulle kunna antyda att de var ur nunnornas samling. Att döma av det övriga stulna som listas kan böckerna emellertid lika gärna ha tagits från brödernas bibliotek. ${ }^{158}$

Enligt Birgittas instruktioner hörde skrivarbetet/boktillverkningen till de dagliga arbetsrutinerna i klostret. ${ }^{159}$ Lucidarium stadgar att "... the systra som kunno scriffua, gangin til at scriffua, Oc de som skulu owirläsa, gangin til at rätta bökir,"160 Andra systrar som kan sy, brodera eller språnga ${ }^{161}$ går dagligen till sina arbetsuppgifter, var och en efter sin kompetens. ${ }^{162}$ Av nunnornas bokföring, som är bevarad

153 Databasen Illuminerade handskrifter i Sverige omfattar 97 illuminerade handskrifter av Vadstenanunnorna medan 68 anses vara skrivna av bröderna. Det totala antalet Vadstenahandskrifter är över 300.

154 Directorium chorii är enligt muntlig uppgift från musikvetaren docent Karin Strinnholm Lagergren en för Vadstena kloster unik boktyp som inte påträffats i andra sammanhang.

155 Undantag är de med Vadstenadelar sammanbundna engelska 1200-talspsalterierna C 460 och C 465.

156 Andra samlingar med fler än enstaka exemplar är Linköpings stifts- och länsbibliotek och Riksarkivet i Stockholm.

157 Tre handskrifter finns nu i Tyskland: Staatsbibliothek zu Berlin, Preussiger Kulturbesitz, MS Germ. 726 folio, Theol. Lat. No. $718^{\circ}$, Giessen, Grossherzogl. Universitäts-bibliothek MS $8818^{\circ}$.

158 Sandgren ”Prosperity and poverty" 2017 s 236, Silfverstolpe 1895 s XIII-XIV. Fredriksson 1996 och Walta 2014 har behandlat brödernas bibliotek, se Fredriksson 1996 och Walta, Ville, Libraries, manuscripts and book culture in Vadstena Abbey, University of Helsinki, Diss. Helsinki, 2014.

159 Regula Salvatoris kap. 23. Lundén bd IV 1959 s 33.

160 Klemming 1883-84 s 81.

161 Språngning var en vanligt förekommande garnteknik.

162 ” Oc hwarie enne systir skipis the gerning oc ärffuode som hon är bätzst qwämmelik til, äpter 
från 1500-talets mitt, framgår att man fortsatte köpa in skrivmaterial även när bröderna tvingats ut från klostret. ${ }^{163}$ Det var en skrivartradition som upprätthölls av nunnorna, trots tryckkonstens stora expansion i samtiden. ${ }^{164}$

De bröder som skrev diariet var sparsamma när det gäller kommentarer om systrarna, men en handfull av nunnorna uppmärksammas vid sitt frånfälle ha varit skickliga i skrivkonsten. En av de första som inträdde i orden och vars kompetens nämns i diariet är Ramborg Staffansdotter som avled på askonsdagen 1410. ”Hon var skicklig i skrivkonsten och i annat som hörde till systrarnas tjänst," ${ }^{165}$ noterade diariets skrivare. Betydligt fler systrars bokliga kompetens är kända från decennierna kring sekelskiftet 1500. En av de mest produktiva var Christina Hansdotter (Brask) som inträdde 1459 och avled 1520. Diarieskrivaren noterade i hennes dödsnotis att hon hade "skrivit av ett flertal böcker", ${ }^{166}$ ett faktum som de bevarade handskrifterna bekräftar. Hitintills har hennes handstil påträffats i nästan tjugotalet verk och det händer fortfarande att verkslistan utökas av nya fynd.

Boktillverkningen i klostret omtalas inte mycket mer i dokumenten än att man ska skriva och korrekturrätta böcker, som i citatet ovan. Att ledningen för klostret hade skrivkompetens var lika nödvändigt som självklart, men för att klara de sextio nunnornas bokliga behov krävdes naturligtvis att fler hade skrivkompetens. Citatet ur Lucidarium visar inte bara att några hade till uppgift att skriva/kopiera text. Uttryckligen sägs också att några skulle rätta de skrivna böckerna. En sådan funktion framstår i skriptoriesammanhang som något överordnad och krävde en viss erfarenhet. Även denna form av "översyn” på verksamheten kommenteras i diariet, men endast undantagsvis och då för brödernas vidkommande. ${ }^{167}$ Korrekturläsningsfunktionen måste rimligen ha praktiserats i båda konventen. En felskrivning i ett psalterium kunde lätt leda till felläsning, dvs. "oljud" i koret. Själva bokbindandet verkar det däremot som om man haft specialiserade bröder till att utföra. Med hjälp av en snurrtunna och draglåda i samtalsrummet (på gränsen mellan de båda konventen) kunde man enkelt skicka t.ex. böcker mellan konventen för bindning.

Den medeltida person som kunde läsa kunde inte med nödvändighet också skriva, det var två olika färdigheter, men uppenbarligen hade man något slags undervisning för systrarna inom klostret. Tillägget till klosterregeln påtalar att det skall finnas någon eller ett par äldre systrar som undervisar de yngre/nya systrarna i att sjunga och läsa. ${ }^{168}$ Man kan också gissa att lärarinnan Ragnhild Toresdotter, som invigdes 1408 tillsammans med sin adept hertigdottern Ingeborg Gertsdotter av Holstein, kunde bistå klostret med undervisning av fler än den lilla 11-åriga flicka

abbatissa wilia.” Klemming 1883-84 s 81.

163 Silfverstolpe 1895 s 94 (1559), 102 (1561), 144-145 (1545), 148.

164 För vissa uppdrag har man anlitat externa skrivare enligt räkenskaperna. Man köpte aldrig in någon ny tryckeriutrustning efter att tryckpressen brann upp samma år som den inskaffades 1495, se DV 921.

165 DV 181.

166 DV 705, 1063.

167 DV 476.

168 Klemming 1883-84 s 135. 
som hon medföljde. ${ }^{169}$ Ytterligare en indikation på läs/skrivkunnighet är de systrar som vid olika tillfällen sändes ut till de nyetablerade dotterklostren. Till de viktiga färdigheter som bör finnas i en sådan pionjärtrupp hör naturligtvis både läs- och skrivkunnighet. För även om man hade med sig en grunduppsättning av de mest viktiga böckerna till det nya stället, så behövdes det snart fler i takt med att kommuniteten växte. Att producera egna skrifter var inte bara en viktig intern resursfråga utan också viktigt av juridiska och ekonomiska orsaker.

I Birgittas klosterregler finns ett par intressant upplysningar av förbudskaraktär som har koppling till böcker. I klosterregelns kapitel 2 sägs att det är förbjudet för klosterfolket att inneha/hantera guld eller silver annat än för tillverkningen av paramenta. ${ }^{170}$ Följer man budet kan man inte förgylla t.ex. anfanger eller marginaldekorer i böckerna. I brödernas sedvanebok, Liber usuum, står dessutom att generalkonfessorn inte får avyttra böcker (byta, sälja, ge) utan brödernas samtycke och att eventuella inkomster från bokförsäljning skall gå direkt till kostnader för att laga eller göra nya böcker. ${ }^{171} \mathrm{Av}$ det sistnämnda kan man sluta sig till att klostret kunde byta till sig böcker och göra böcker åt andra utanför klostret. Detta är inte så märkligt och förekom i de flesta kloster. Däremot var det inte tillåtet i Vadstena att göra det för ekonomisk vinnings skull. Det förstnämnda förbudet, guldförbudet, är lite problematiskt om man ser till de bevarade handskrifterna. Från systrarnas skriptorium finns nämligen ett antal handskrifter som har dekorerats med både silver och guld, men i varierande omfattning. Tidsmässig hör de hemma i decennierna från sent 1400-tal fram till 1530-talet. Eftersom det samtidigt är väldigt få handskrifter kvar från Vadstenasystrarna som tillkommit under klostrets första hundra år, kan dessa sena och påkostade handskrifter ge en skev bild av verksamheten i nunnornas skriptorium. Bland de få äldre Vadstenatillverkade handskrifterna har å andra sidan hitintills inte något guld eller silver påträffats. ${ }^{172}$ Det finns alltså en intressant motsättning mellan systrarnas skriptoriepraktik och guldförbudet i klosterregeln, åtminstone när det gäller den senare delen av klostrets existens. Samma diskrepans mellan regeln och handskrifterna visar sig också i de få handskrifterna som bevarats från Munkalivs kloster i Bergen. Både Barbara Torkelsdotters bönbok (UUB C 448) och det så kallade Munkalivspsalteriet är rikt illuminerade med förgyllda anfanger. ${ }^{173}$

169 DV 169.

170 Regula Salvatoris kap. 2. Lundén bd IV 1959 s 14.

${ }^{171}$ Risberg, Sara (red.), Liber usuum fratrum monasterii Vadstenensis, Diss. Stockholm: Univ., 2003 s 33 .

172 De illuminerade verk som skapats i brödernas skriptorium tycks, i överensstämmelse med klosterregeln, inte ha några guld eller silverdekorationer. Se vidare kapitel 3.

173 UUB C 448 respektive Prag, Archiv Prazskeho hradu, ms Cod. Capit. B 4/1. Bilder ur C 448 se https://www.alvin-portal.org/alvin/view.jsf?dswid=-3033\&searchType=EXTENDED\&query $=\mathrm{C}+448 \& \mathrm{aq}=\% 5 \mathrm{~B} \% 5 \mathrm{~B} \% 7 \mathrm{~B} \% 22 \mathrm{~A} \_\mathrm{FQ} \% 22 \% 3 \mathrm{~A} \% 22 \mathrm{C}+448 \% 22 \% 7 \mathrm{D} \% 5 \mathrm{D} \% \mathrm{D} \& \mathrm{aqe}=\% 5 \mathrm{~B} \% 5 \mathrm{D}$ \&af=\%5B\%5D\&pid=alvin-record\%3A116080\&c=2\#alvin-record\%3A116080 (20200312). 
I praktiken måste man ha haft ett skriptorium för vardera av de båda konventen. ${ }^{174}$ Hos bröderna hade sakristanen ansvar för boksamlingen, ${ }^{175}$ men det nämns ingenstans att någon av systrarna i Vadstena skulle ha ett särskilt ansvar för deras skriptorium eller boksamling, och det finns inga ekonomiska spår av verksamheten i räkenskaperna annat än sporadiskt, och då främst under 1500-talet. Från dotterklostret Syon Abbey i London finns däremot den kvinnliga sakristanens räkenskaper bevarade, vilka visar på hennes ansvar för systrarnas skriptorium. ${ }^{176} \mathrm{Om}$ Vadstenasystrarnas läsning till bords och i kyrkan finns det däremot många instruktioner, och det finns en stor mängd ansvarsuppgifter som roterade mellan systrarna, men inget som uttryckligen har med skriptoriet att göra. ${ }^{177}$

Det manuella arbete som utfördes av systrarna pågick några timmar varje dag och avslutades vid vespern på eftermiddagen. Klosterregelns tjugonde kapitel stadgar att den tid som systrarna inte är i bön eller gudstjänst så skall de "wara j handa gjerningh" ${ }^{178}$ De aktuella sysslorna hörde inte till det tyngre arbetet, dem var det leksystrar som skötte. Arbetet utfördes i ett gemensamt arbetsrum, där abbedissan hade sin plats i ena änden, från vilken hon kunde övervaka arbetet och disciplinen. ${ }^{179}$ Rummet skulle ha bekväma stolar och stora fönster. ${ }^{180}$ Med tanke på dåtida belysningsmöjligheter var det ett klokt påbud för detta rums utformning. Det finns inga dokument som fastställer exakt i vilken byggnad arbetsrummet inrymdes. Vanligtvis placeras det i norra längans bottenvåning. ${ }^{181}$ Där hade man i så fall dagsljus från söder, som lyste upp det stora rummet.

Enligt klosterregeln skulle veckans arbete visas upp för abbedissan på lördagar. ${ }^{182}$ För övrigt ges inte specifika instruktioner om hur arbetet hos systrarna gick till. Istället får det materiella, dvs. de bevarade handskrifterna och textilierna, tas som vittnen till hur det immateriella var organiserat, dvs. hur arbetsfördelningen kan ha sett ut i praktiken. Flertalet av de bevarade handskrifterna härstammar som sagt från decennierna kring 1500 och kunskaperna om skriptorieverksamheten under första halvan av 1400-talet är därför begränsad. Ingela Hedström har undersökt ett antal av systrarnas bönböcker och identifierade handstilar som vittnade om ett stort antal skrivande nunnor. Så många som en femtedel av det totala antalet systrar kan knytas till någon form av skrift/bokaktivitet, men eftersom en stor del av handskrifterna gått förlorade måste även antalet bokligt aktiva systrar ha varit betydligt högre. ${ }^{183}$

\footnotetext{
174 Se vidare nedan kapitel 3 om brödernas böcker.

175 Se exempelvis DV 476.

176 Erler, Mary, "Syon Abbey's care for books: its sacristan's account rolls 1506/7-1535/6", Scriptorium 39, 1985, s 293-307.

177 Klemming 1883-84 s 94-100 förtecknar 16 veckoämbeten och ytterligare liturgiska funktioner till ett totalt antal av 29 sysslor. Se även Rajamaa 1992 s 143-173.

178 Klemming 1883-84 s 80.

179 Klemming 1883-84 s 82.

180 Klemming 1883-84 s 81-82.

181 Sigurdson, Julia M. \& Zachrisson, Sune, Aplagårdar och klosterliljor: 800 år kring Vadstena klosters bistoria, Artos, Skellefteå, 2012 s 88, Berthelson 1947 s 152.

182 Klemming 1883-84 s 83.

183 Hedström 2009 s 88, 108-113.
} 
I genomsnitt innebär det att mellan tio och femton av de sextio systrarna var verksamma inom det bokliga arbetet samtidigt. Det är den enskilt största gruppen sett till de cirka trettio olika uppgifterna nunnorna hade att fördela mellan sig i klostret. Hur de däremot fördelade skriptoriearbetet mellan sig finns inga upplysningar om alls. Till de andra roterande veckoämbetena hörde att minst fyra av systrarna hade till uppgift att sköta om de liturgiska kläderna. Ytterligare tolv systrars arbetsuppgifter listas i Klemmings utgåva av Lucidarium. ${ }^{184}$ Till dessa uppgifter kommer de liturgiska ansvarsuppgifterna för lektris, rectrices chori (=cantrix, succentrix), horista (=hebdomadaria), två versikelsystrar, två klädessystrar samt fyra så kallade custodes ordinis. Regeln nämner som sagt också att ett par av systrarna hade till uppgift att lära de unga systrarna att läsa och sjunga, vilket skulle kunna sammanfalla med custodernas uppgifter. ${ }^{185}$ Dessutom hade priorinnan och abbedissan sina både praktiska och liturgiska funktioner. Däremot nämns inte ordet sakristan i detta sammanhang, men ordet används i diariet för fem avlidna nunnor. ${ }^{186}$ Sammantaget täcker arbetsuppgifterna trettioen personer, hälften av maxantalet nunnor, men till dessa måste läggas även de tio till femton nämnda skriverskorna i skriptoriet.

Förutom Ingela Hedström är det främst Jonas Carlquist och Monica Hedlund som arbetat med skriverskornas olika handstilar, i fornsvenskan respektive latinet. Det är i huvudsak deras forskning om de skrivande nunnorna som jag bygger vidare på. Många, för att inte säga flertalet av handskrifterna är utförda av mer än en skriverska. ${ }^{187}$ Generellt sett skriver nunnorna i två huvudsakliga skrifttyper: hybrida för fornsvenskan och textualis för latinet (se bild 16 och 18 för skriftjämförelse). Dessutom använder de på traditionellt manér rött bläck till rubrikerna och inledningarna till bönerna. De liturgiska avsnitten är däremot skrivna med svart bläck, oftast i en något större stil än de röda rubrikerna (se t.ex. bild 16, 18, 20). En viktig kännedom om skriverskornas identiteter kommer från deras egna kommentarer och signaturer i böckerna. Tyvärr är dessa signaturer och kommentarer varken systematiskt tillämpade eller enkla att tolka. Vissa forskares iver att identifiera individer bland skriverskorna har ibland lett till övertolkningar av de initialer som förekommer i materialet. Detta gäller både handskrifterna och textilierna. ${ }^{188}$ Tydliga referenser till en av systrarna ges exempelvis i bönboken A 80 i Kungliga biblioteket i Stockholm, där man i flera av de röda rubrikerna kan läsa bokstäverna $b a$ tillsammans med olika

184 Klemming 1883-84 s 94-100.

185 Klemming 1883-84 s 135. Se även Rajamaa 1992 kap 7 för diskussion om arbetsuppgifterna samt Viveca Servatius Cantus sororum: musik- und liturgiegeschichtliche Studien zu den Antiphonen des birgittinischen Eigenrepertoires: nebst 91 Transskriptionen, Diss., Uppsala, 1990.

186 DV 436 Margareta Gregersdotter, DV 650 Anna Clausdotter, DV 919 Ragnhild Unnesdotter, DV 990 Ingeborg Larsdotter, DV 1004 Christina Övidsdotter. Diariet nämner endast fyra manliga sakristaner. Räkenskaperna nämner också utgift till en sakristan bland nunnorna, Silfverstolpe 1895 s 72 .

187 Hedström 2009 s 196 ger en lista med 58 unika skrivarhänder i sammanlagt 17 studerade handskrifter.

188 Hedström 2009 s 88-91, 111-112 och Räsänen, Elina, ”The Vallis gratiae Altar frontlet: Object, Imagery, and Deconstruction of the 'Artist', The Birgittine Experience, papers from the Birgitta Conference in Stockholm 2011, KVHAA Konferenser 82, Stockholm 2013 s 127-129 ger flera exempel. 


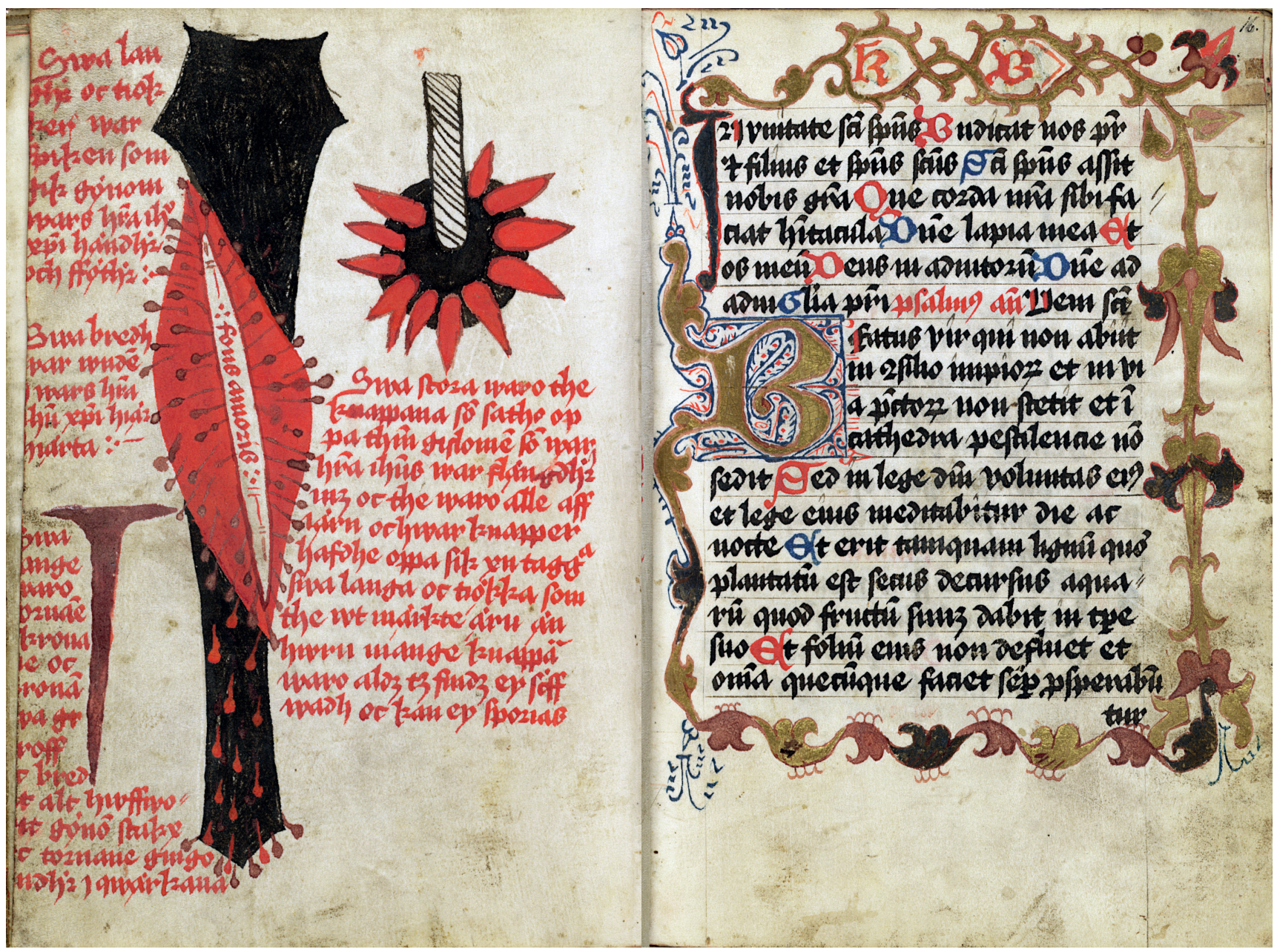

Bild 15. Kristi sidosår och några av passionsredskapen. Till vänster ses en brun törnetagg, en stor svart spik med det blödande såret och texten "fons amoris", samt en strigel. Den svenska texten är skriven med rött bläck och garanterar att föremålen är avbildade i naturlig storlek. Uppslaget inleder Heligen Andes tidegärd i Birgitta Andersdotters bönbok, senare Katarina Bengtsdotters. Raderingen av den första ägarens initialer framstår som en skugga runt de senare ditfogade initialerna KB. Kungliga biblioteket ms A 80 f. 15v-16r. Beskuren. (C) KB.

formuleringar som uppmanar till förbön. I den övre marginalen på inledningssidan till de liturgiska texterna (f. 16r) finns spår av ett stort raderat $B A$ som skrivits över med de gyllene bokstäverna $K B$. (Bild 15.) Tolkningen av dessa initialer får anses stå sig: $b$ a syftande på Birgitta Andersdotter och $k b$ syftande på Katarina Bengtsdotter (Gylta). Kronologiskt är detta helt i sin ordning, eftersom syster Birgitta levde i klostret före Katarina Bengtsdotter (Gylta). ${ }^{189}$ Dessa två nunnor antas ha varit bokens ägare/brukare i kronologisk ordning. Skriverskan Christina Månsdotter (1518-55)

189 Birgitta Andersdotter avled 1532, Katarina Bengtsdotter (Gylta) inträdde 1546. Silfverstolpe, Carl, Klosterfolket i Vadstena: personbistoriska anteckningar, Norstedt, Stockholm, $1898 \mathrm{nr} 266$ respektive 19 (s 3-5). 
ger sina initialer på flera ställen här och i handskriften C 502 (som också tillhört Birgitta Andersdotter). ${ }^{190}$

\section{Var skriverskorna även illuminatriser?}

Vi ska nu gå in på frågan om hur den interna arbetsfördelningen i nunnornas skriptorium kan ha sett ut, för att bland annat undersöka om en skriverska också kunde vara illuminatris, bokmålarinna. Det handlar alltså inte primärt om bildbruket i kyrkan, utan om tillverkningen av handskrifterna och utformningen av deras visuella gestaltning. Samtidigt gäller det främst de handskrifter som nunnorna använde i kyrkan. ${ }^{191}$ Deras bönböcker och liturgiska böcker. När det gäller de diskuterade handskrifternas signumbeteckningar så är som tidigare nämnts samtliga A-signum handskrifter från Kungliga biblioteket. De som betecknas med C är handskrifter från Uppsala universitetsbibliotek. E-handskrifterna ingår i Riksarkivets samlingar och Mh betecknar verk ur samlingen i Lunds universitetsbibliotek. Tre av de diskuterade handskrifterna finns i Linköping (B- och T-signum). Det förekommer också Vadstenahandskrifter i Tyskland (Berlin, Gießen), Storbritannien (Lampeter), i den Arnamagnanska samlingen i Köpenhamn (signum AM) samt Gävle gymnasiebibliotek och på Ängsö slott. Det är ytterst få verk som kan uppkallas efter en viss ägare eller brukare eftersom individerna för det mesta är oidentifierade. Framställningen nedan bygger på värdefulla forskningsinsatser av främst professor Monica Hedlund och fil. dr Ingela Hedström, vilka har studerat nunnornas skriftliga verk på latin respektive fornsvenska. ${ }^{192}$ Tillsammans har vi studerat samma handskrifter, men ur olika perspektiv.

Flera av Vadstenasystrarna tillbringade ett långt liv i klostret, några så många som sextiotalet år. Det innebär att de arbetade i samma rum och producerade text under lång tid, i nära samarbete med varandra. Skrivarskiftena i handskrifterna visar att t.ex. en bönbok som påbörjades av en syster ofta kunde gå vidare till flera av skriverskorna innan den blev klar. Dessa faktorer gör bilden av skriptoriearbetet komplext.

Med sina sextioen professår var syster Christina Hansdotter (Brask) inte unik i klostret, men hon har lämnat ett enastående handskriftsœuvre efter sig med nära tjugo identifierade verk. I några fall har hon lämnat sina initialer $c h$ som en signatur i sina verk, och ofta uppvisar hon en så pass tydligt särpräglad stil att hennes skrivarhand är förhållandevis lätt att identifiera. ${ }^{193}$ Till de identifierade skriverskor som var aktiva samtidigt som Christina Hansdotter hör Anna Svensdotter (1478-1527) och Katarina Johansdotter Gudmundi (1476-1519). Enligt Ingela Hedströms forskning

\footnotetext{
${ }^{190}$ KB A 80 folio 39v, 45r, 82v, 112v, 166v, 168r, 201r. UUB C 502 folio 23v.

191 För en översikt av de aktuella nunnorna och handskrifterna finns en lista i bilaga 1.

192 Latinisten Monica Hedlund medverkade i C-katalogen över handskrifterna i UUB och har skrivit ett flertal artiklar/konferensbidrag som berör nunnornas skrivande. Nordisten Ingela Hedströms avhandling används i det följande för det svenskspråkiga innehållet i handskrifterna. Även nordisten Jonas Carlquist har studerat nunnornas skriftliga verksamhet, men inte lika mycket frågan om vem som skrev vad och i vilken handskrift.

193 Hedström 2009 s 66-67.
} 
har Christina Hansdotter (Brask) samarbetat med båda dessa skriverskor i A 81, AM 422 och C $475 .{ }^{194}$ Hedström har kunnat särskilja sammanlagt nitton skriverskor i bara dessa tre bönböcker. Förutom de tre nyss namngivna systrarna är de övriga sexton inte identifierade i något annat verk. ${ }^{195}$ En namnkänd skriverska som verkade generationen efter dem är Christina Magnusdotter (1518-55). Till hennes verk räknas bland annat C 502, A 80 (Birgitta Andersdotters bönbok) och Rålamb 4 in $8^{\circ}$ (Christina Nilsdotter Gyllenstiernas bönbok). ${ }^{196}$ Hedström urskiljer vidare en oidentifierad skriverska som verkat i de tre bönböckerna Berlin Theol lat 71, Gießen 881 och E $9068 .{ }^{197}$ I Gießenhandskriften finns därtill en namngiven skriverska som skriver parallellt med den nyssnämnda Christina Magnusdotter, nämligen Margareta Olofsdotter (1517-1543), samt tre oidentifierade händer. ${ }^{198}$ (Se bilaga 1.) Skriftanalysen visar tydligt att en mängd olika skriverskor kan särskiljas i handskrifterna, men av dem är bara ett fåtal möjliga att knyta till kända namn i klostret.

Det är inte bara skriften som kan användas för att identifiera de olika skriverskornas verk. Studerar man dekoren i handskrifterna så finns det en påtaglig samvariation mellan skrivarskiftena och skiftena i dekorens detaljutformning. Frågan är om skriverskorna huvudsakligen också illuminerade de delar som de ansvarade för att kopiera? De illuminationer som det här är frågan om är förgyllda och polykroma initialer och penntecknade så kallade filigrandekorer i blått och rött (eng. penflourished). (De få miniatyrerna måste uteslutas ur detta resonemang eftersom de huvudsakligen är inlimmade tryckta bilder.) På samma sätt som bokstävernas form har olika egenheter beroende på vem som format dem har olika skriverskor haft olika personliga sätt att i detaljerna forma marginalrankor, hängen och initialer. De färgnyanser som använts och hur bladguldet hanterats kan också indikera att olika bokmålare varit aktiva. I exempelvis Christinas (Brask) förgyllda verk är bladguldet applicerat utan bolusgrundering, troligen med hjälp av äggvita som bindemedel. Guldet har nämligen en torr krackelerad yta, vilket man kan se i exempelvis C 12 och C 443, båda skrivna helt av henne. (Bild 16.) Christina Magnusdotter har som jämförelse lagt en tjock rosa grund för bladguldet. Det gör att hennes guldinitialer är fylligare och reser sig från pergamentytan, vilket man kan se i Rålamb 4 in $8^{\circ}$ och A 80. (Bild 15.) ${ }^{199}$ Det är inte bara anläggandet av guldet och de stora initialernas avsaknad av vidhängande marginaldekor som är karaktäristiska för Christina Hansdotter (Brask). Den stora förgyllda initialen skulle kunna inneslutas i en ruta och i hörnen finns utsparade konkava urgröpningar. Hon har använt vit färg för detaljerna, men till skillnad från vad som är brukligt inom bokmåleriet lägger

194 Hedström 2009 s $162 f f$ identifierar nio olika skriverskor i C 475.

195 Hedström 2009 s 196.

196 Christina Nilsdotters (Gyllenstierna) bönbok har getts ut med kommentarer av Jonas Carlquist och Jan Carlquist: Nådigfru Kristinas andaktsbok, Libris, Örebro 1997.

197 E-serien hör till Riksarkivets samlingar i Stockholm.

198 Hedström 2009 s 183.

199 Se exempel i Sandgren, Eva Lq, ”Det marginaliserade bokmåleriet i Vadstena kloster”, Bilder i marginalen: nordiska studier $i$ medeltidens konst, Nordiska symposiet för ikonografiska studier, red. K. Markus, Argo, Tallin 2006, densamma "Birgittinska bönboksbilder" 2014 och "Christina Hansdotter Brask" 2017. 


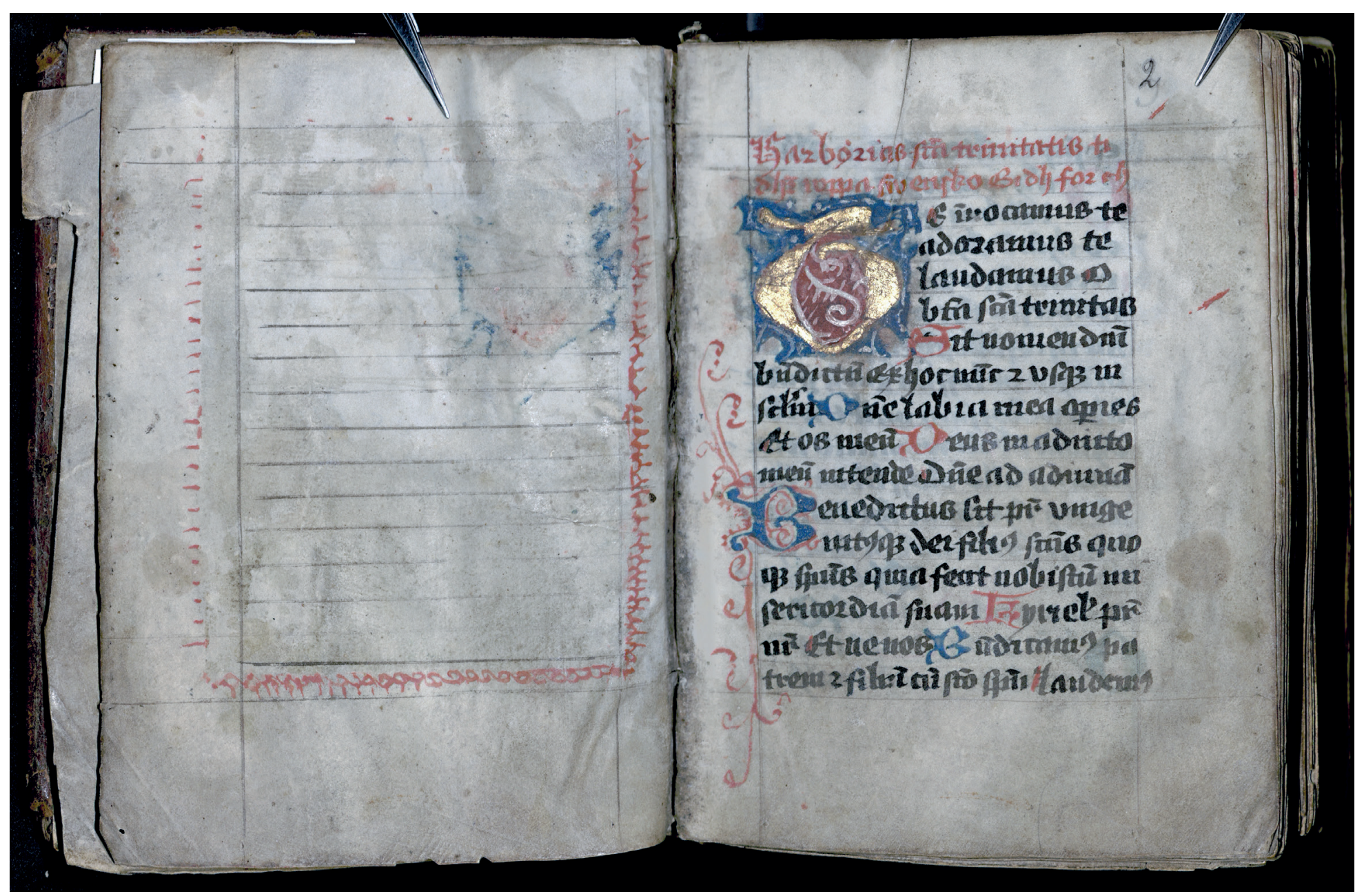

Bild 16. Bönbokens inledande uppslag visar spår av en ram kring en försvunnen helsidesbild på vänster sida. I marginalen bredvid den inledande röda rubriktexten på höger sida ses även spår av en röd tunn oval ram som omgett en liten mandelformad bild. Uppslaget inleder Helga trefaldighets tidegärd. UUB C 12 f $1 v-2 r$. C UUB.

hon inte någon konturavgränsande mörk tunn linje runt ytterkanterna. Initialernas utformning skiljer sig också från en stor del av Vadstenamaterialet och sin samtids bokmåleri, genom att inte ha någon utlöpare i marginalen.

De båda Christinornas illuminationer skiljer sig också åt på andra vis och kan vara en lämplig jämförelse även gentemot andra skriverskor/illuminatriser i klostret. Christina Hansdotters (Brask) initialdekorer förtjänar ofta beskrivningen spretiga och vingliga. I takt med att hennes skrift blir allt darrigare och oregelbunden blir också måleriet darrigare. I hennes verk förekommer två huvudsakliga typer av dekorerade initialer. Boksidan ur bönboken C 12 visar exempel på dessa. (Bild 16.) På samma sätt som guldet ser ojämnt ut i hennes måleri har likaså det polykroma måleriet en torr yta med kladdig linjeföring, som om färgen hade behövt mer vätska för att flöda bättre på ytan. 


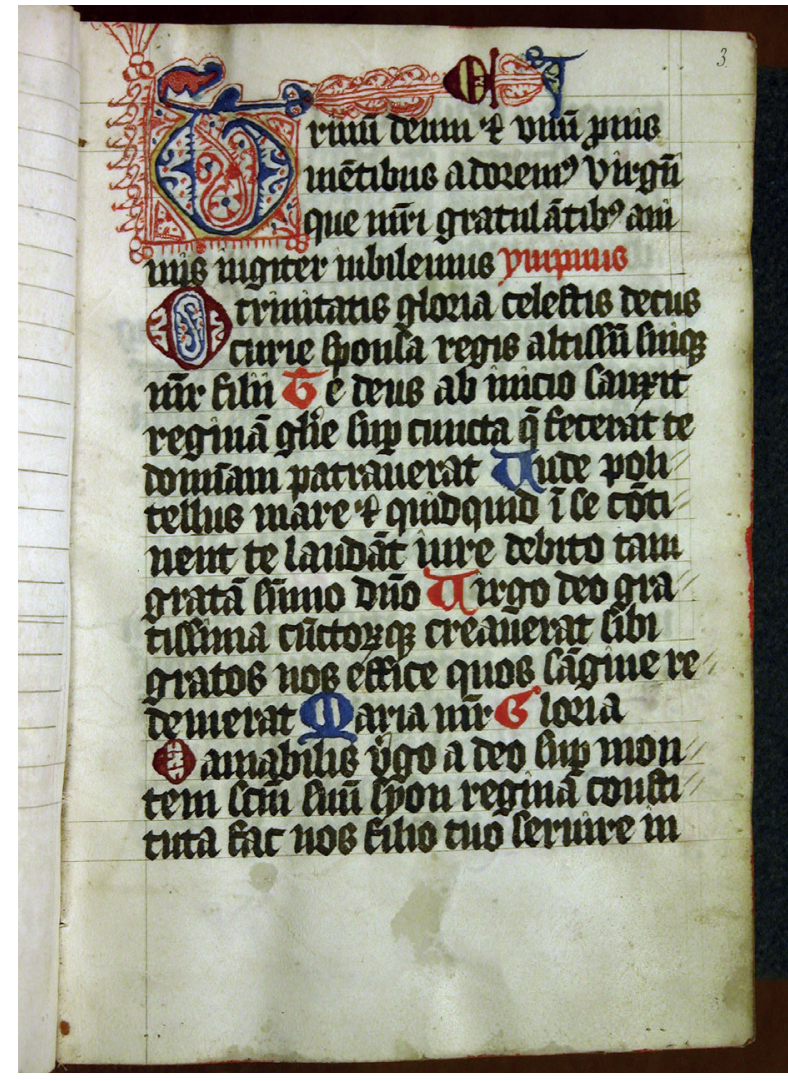

Bild 17. En tidebok och ett par av processionsböckerna från Vadstenanunnorna har en utformning av den omgivande dekoren som skiljer sig frän de flesta andra av nunnornas handskrifter. Dekorernas konturer ger ett vasst, taggigt intryck och är målade med en mindre flödande färg. I tideboken C $432 \mathrm{f} 3 \mathrm{r}$ har initialerna $C J$ fogats in $i$ den övre marginalens rankverk och trots att de fått en avvikande färg är de inte helt lätta att upptäcka. (c) UUB.
Den mindre initialen i bilden ur C 12 är utförd som filigran, en mycket vanlig dekortyp under en stor del av medeltiden. Blått och rött är standardkombination och används flitigt också i Vadstena. Även i detaljutförandet av dessa initialer finns egenheter i Christina Hansdotters (Brask) måleri som gör att man oftast kan särskilja hennes hand från flera av medsystrarna. Typiskt för hennes verk är att den övre marginalstjälken skjuter upp från vänstra delen av A:et i ungefär $45^{\circ}$ vinkel. Marginalspröten utgår direkt från initialens inramning och skjuter ut i flera mjuka krokar, staplade efter varandra. De tunna stjälkarna växer mestadels ut från samma bas. Krokarna böjer sig in mot stammen och avslutas av ett eller två korta tvärgående streck följt av en C-formad krok. Söker man efter dessa karaktäristika i Vadstenahandskrifternas dekorer så finner man initialer av Christina Hansdotters (Brask) hand i även A 4 och E 9002. Den tryckta tideboken UUB Sv rar 10:223 har också en handmålad initial som stämmer väl in på hennes måleristil, vilket stärker tidebokens Vadstenaproveniens. Christina tycks även ha varit aktiv som bokmålare i Cantus sororum-handskrifterna C 484 och C $490 .{ }^{200}$ En tydligt avvikande, men liten grupp, utgör dekoren i handskrifterna C 432, C $472^{201}$ och C $473^{202}$ som har vassa spetsiga och tätt vågtandade initialsidor med krokar i vågtopparna, och som förutom blått gärna använder både mörkrött och ljusrött bläck i kombination med gult. (Bild 17.) Anfangernas kontur ger ett vasst, taggigt intryck och är målade med en mindre flödande färg. I dessa tre verk var Christina Hansdotter (Brask) skriverska. Det finns drag i dekoren som pekar mot att hon utfört även den, men i en annan modus än vad som är den dominerande formen i hen-

200 Band 5 av åttabandsverket Mittelalterliche Handschriften der Universitätsbibliothek Uppsala: Katalog über die C-Sammlung, red. Andersson-Schmitt, Margarete, Hedlund, Monica \& Hallberg, Håkan, Univ., Uppsala, 1988-1995 (i fortsättningen förkortat MHUU) gavs ut 1992 men identifierar ingen skriverska i dem och de behandlas inte av Hedström 2009. Enligt muntlig uppgift från Hedström 2018 kan de vara skrivna av Christina Hansdotter (Brask).

201 Se https://www.alvin-portal.org/alvin/view.jsf?dswid=2849\&searchType=EXTENDED\& query $=\mathrm{C}+472 \& \mathrm{aq}=\% 5 \mathrm{~B} \% 5 \mathrm{~B} \% 7 \mathrm{~B} \% 22 \mathrm{~A} \_\mathrm{FQ} \% 22 \% 3 \mathrm{~A} \% 22 \mathrm{C}+472 \% 22 \% 7 \mathrm{D} \% 5 \mathrm{D} \% 5 \mathrm{D} \&$ aqe $=\% 5 \mathrm{~B} \% 5 \mathrm{D} \& \mathrm{af}=\% 5 \mathrm{~B} \% 5 \mathrm{D} \& \mathrm{pid}=$ alvin-record\%3A116052\&c=1\#alvin-record\%3A116052.

202 Se https://www.alvin-portal.org/alvin/view.jsf?dswid=2849\&searchType=EXTENDED\& query $=\mathrm{C}+473 \& \mathrm{aq}=05 \mathrm{~B} \% 5 \mathrm{~B} \% 7 \mathrm{~B} \% 22 \mathrm{~A} \_\mathrm{FQ} \% 22 \% 3 \mathrm{~A} \% 22 \mathrm{C}+473 \% 22 \% 7 \mathrm{D} \% 5 \mathrm{D} \% 5 \mathrm{D} \&$ aqe $=\% 5 \mathrm{~B} \% 5 \mathrm{D} \& \mathrm{af}=\% 5 \mathrm{~B} \% 5 \mathrm{D} \& \mathrm{pid}=$ alvin-record $\% 3 \mathrm{~A} 116054 \& \mathrm{c}=2 \#$ alvin-record $\% 3 \mathrm{~A} 116054$. 
nes verk. Den torra penselföringen stämmer väl överens med hennes sätt att hantera färgerna. ${ }^{203}$

Som konstaterades ovan hörde Christina Magnusdotter till generationen efter Christina Hansdotter (Brask), och hon har utfört initialer i C 502, Rålamb 4 och A 80. Hedström karaktäriserar Christina Magnusdotters skrift som driven, lätt högerlutande, rundad och placerad en bit över linjen. ${ }^{204} \mathrm{I}$ utformningen av dekoren visar det sig att den rundade stilen och drivna linjen följer med. Hon tar så att säga ut svängarna med både pennan och penseln. (Bild 18.) De tre handskrifterna som kopierats av henne uppvisar även ett karaktäristiskt lite spretigt utförande i de blå-röda marginalrankorna, samtidigt som de stora anfangerna ofta har svulstiga former och är försedda med akantushängen. Hon kombinerar också guldinitialer med blå-röda filigran-utsmyckningar i många fall. I Christina Magnusdotters initialer förekommer vågformade ytterkanter, fransade kanter och avslutande blommor och akantusblad. Uddarna på de vågformade kanterna är stora, grova och spetsiga, vilket ses även på andra boksidor i C 502. (Bild 19.) På dessa boksidor syns stora marginalhängen som växer ut från de stora initialernas hörn. Ibland låter hon en tvåfärgad frans löpa längs med initialdekorens yttre linje, som i C 502 folio 2r. Jämför man med A 80 och Rålamb 4 så ser man också att färg-

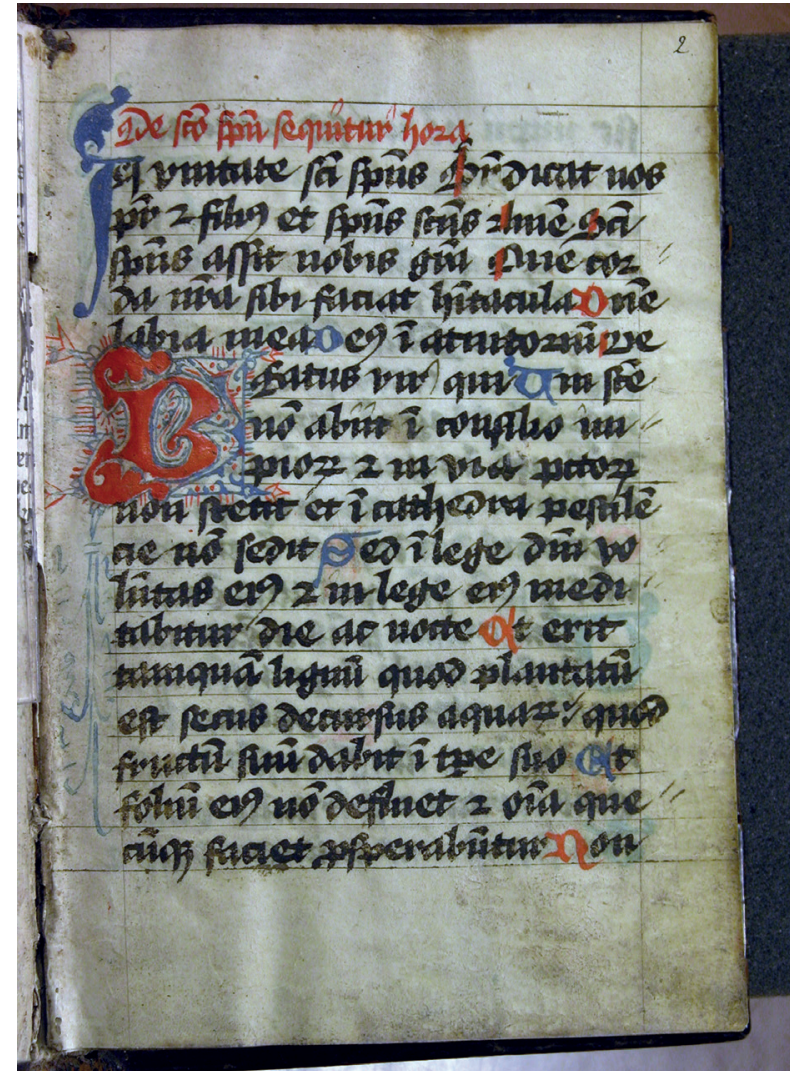

Bild 18. Tideboken C 502 är en av de handskrifter som är skriven av Christina Magnusdotter. Den är utförd i en lätt bögerlutande driven stil, strax ovanför skrivlinjen. Den röda anfangen har en bleknad dekor $i$ blätt och rött med fransar och en långt nedhängande ranka. Även dess utformning är kännetecknande för hennes verk. (C) UUB. skalan är ungefär densamma i dem.

De flerradigt höga initialerna i många av Vadstenasystrarnas handskrifter har en enhetlig utformning och omges av en fyrkantig form med hörndekorer. Hörndekorerna skapas av två små rundlar och en avlång spets, eller tre små rundlar i pyramidformad grupp. I hörnpartiernas svicklar på de större anfangerna ses ofta liksidiga delade akantusblad. De stora initialerna i Christina Magnusdotters A 80, Rålamb 4, C 502 och i den lilla Gävlebönboken präglas även av en enhetlig typ av sammansatta knippen av marginalstrån som utgår från en eller två parallella horisontella linjer. När bokmålarinnan formar de utskjutande marginalstjälkarna utgår hon från ett hörnornament bestående av två små rundlar, från vilka en vass udd skjuter ut (C 502 f. 9v). ${ }^{205}$ (Bild 19.) Därefter gör hon ett par (oftast

\footnotetext{
203 C 432 skrevs av Christina Hansdotter (Brask) för en syster med initialerna CJ, vilka är placerade i marginaldekoren på första sidan. Se bild 17.

204 Hedström 2009 s 128.

205 Ibland är det istället tre små rundlar i en pyramidform.
} 


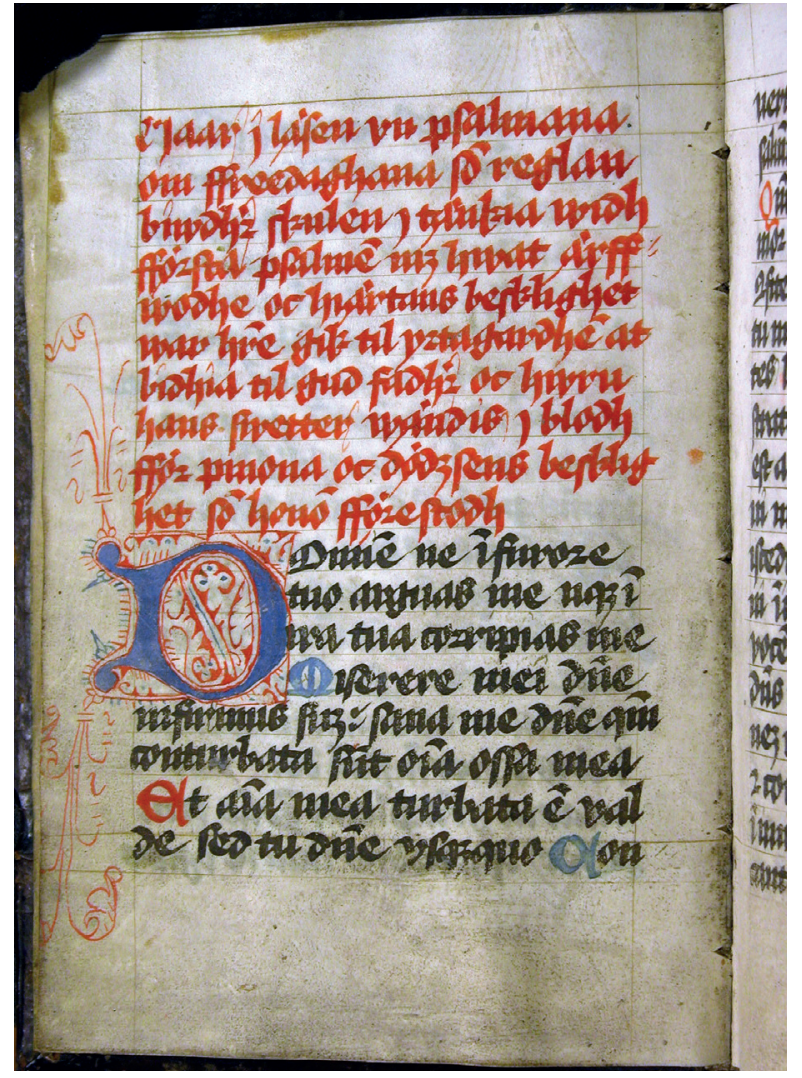

Bild 19. Bilden visar en ganska karaktäristisk utformning av initialdekoren i Christina Magnusdotters verk. Initialen är här utförd i silver (oxiderad) och försedd med en utsparad dekor $i$ rött med blå detaljer. Inuti bokstavens hålrum fylls ytan av "split leaf", kluvna palmetter, och utmed marginalsidan finns en liten frans. Marginaldekoren är lite spretig och innehåller s-formade krokar och kluvna palmettblad. C 502 f. 9v. (c) UUB. fristående) tvärstreck och låter stjälkarna skjuta ut, gärna parvis, i olika nivåer. Marginalstavarna avslutas av två eller tre vågformade parallella linjer och en större Z-formad krok. Tvärstrecken på ändkrokarna kan ibland vara vågiga och till och med förefalla darrhänt utförda. Ibland sitter det ett halvt akantusblad i änden på den längsta stängeln. Medan de större initialerna har ett mer genomarbetat utförande, ger den penntecknade dekoren ett slarvigare intryck. Det är både spretigt och vingligt. Ibland är utförandet snarast slarvigt, som i Gävlebönboken. ${ }^{206}$

Samma typ av förgyllda större anfanger som hos Christina Magnusdotter förekommer i andra systrars dekorer, som i exempelvis C 469, A 1 och A 2, och är ibland svåra att särskilja. Den penntecknade blå-röda marginaldekoren i dem har emellertid inte riktigt samma utformning som i t.ex. A 80. Därför är det inte rimligt att tillskriva Christina Månsdotter dekoren i C 469, A 1 och A 2. För de sistnämnda tre handskrifterna finner man istället en bättre överensstämmelse i dekoren med C 458, där Anna Germundsdotter kopierat texten, ${ }^{207}$ samt i delar av E 9068 (f. 2v, 29r, 88r, 116v-117r). ${ }^{208}$ Anna Germundsdotter skrev även delar av A 3 (f. 81-93, 95-139), medan den syster som dekorerade A 3 uppenbarligen målade alla dess initialer och marginaldekorer.

Ytterligare en identifierad skrivande syster var Anna Svensdotter. Hon inträdde i klostret 1478 och avled 1527, och innehade en tid priorinneämbetet. ${ }^{209}$ Passager av hennes skrivarhand finns i AM 422, A 43 och C $473^{210}$, alla skrivna ihop med andra systrar. ${ }^{211} \mathrm{I}$

206 Huruvida Gävlebönboken faktiskt är skriven av Christina Magnusdotter är inte helt klarlagt.

207 Bilder C 458 se http://www.alvin-portal.org/alvin/view.jsf?dswid=-3033\&searchType= EXTENDED\&query=\&aq=\%5B\%5B\%7B\%22A_FQ\%22\%3A\%22C+458\%22\%7D\%5D\%$5 \mathrm{D} \&$ aqe $=\% 5 \mathrm{~B} \% 5 \mathrm{D} \& \mathrm{af}=\% 5 \mathrm{~B} \% 5 \mathrm{D} \& \mathrm{xid}=$ alvin - record $\% 3 \mathrm{~A} 116064 \& \mathrm{c}=3 \#$ alvin - record $\%$ 3A116064.

208 MHUU bd 51992 s 163, Hedström 2009 s 505ff nämner inga namn på aktuella skriverskor i RA E 9068.

209 Silfverstolpe 1898 s 57, Hedström 2009 s 62.

210 Bilder UUB C 473 se https://www.alvin-portal.org/alvin/view.jsf?dswid=-3033\&searchType= EXTENDED\&query $=\mathrm{C}+473 \& \mathrm{aq}=\% 5 \mathrm{~B} \% 5 \mathrm{~B} \% 7 \mathrm{~B} \% 22 \mathrm{~A} \_\mathrm{Q} \% 22 \% 3 \mathrm{~A} \% 22 \mathrm{C}+473 \% 22 \% 7$ D\%5D\%5D\&aqe=\%5B\%5D\&af=\%5B\%5D\&pid=alvin-record\%3A116054\&c=2\#alvinrecord\%3A116054.

211 MHUU bd 51992 anger Christina Hansdotter (Brask) som ensam skrivare av C 473. 
bönboken A 43 (Ingegerd Ambjörnsdotters bönbok), är Anna Svensdotters dock den dominerande skrivarhanden. ${ }^{212}$ Den förmodade bönboksägarinnans initialer, $i$ a, förekommer tolv gånger, medan skriverskans initialer, as, förekommer fyra gånger. I de flesta fall återfinns initialerna i de röda rubrikerna, men ett intressant undantag ses på folio 159v. (Bild 20.) Där börjar "en godh bön til thin hälga ängil" vars inledande stora J pryds av röda bläckdekorer i snirkliga former. Vid närmare granskning visar det sig att här har initialerna $i$ a och a s infogats i rankverket på ett sätt som kräver uppmärksamhet för att upptäckas. Det är ett sätt att infoga personliga referenser som skiljer sig från de andra skriverskornas. Det mer vedertagna sättet att kommunicera identiteten i rubrikerna ses på den motstående sidan i samma bönbok, folio 160r: "glöm ekke mik i a". Initialerna i a skulle emellertid kunna tolkas som en referens till jungfru Maria - "maia" - förkortat ia, istället för Ingegerd Ambjörnsdotter. Det blir då skriverskan som åkallar jungfru Maria, en för sammanhanget nog så passande tanke. Idén att infoga skriverskans initialer i anfangerna återfinns emellertid även i bönboken $\mathrm{C} 68^{213}$ och på en inklistrad anfang i ett 1512 tryckt tyskt birgittinskt breviarium, UUB Sv rar 10:90..$^{214}$

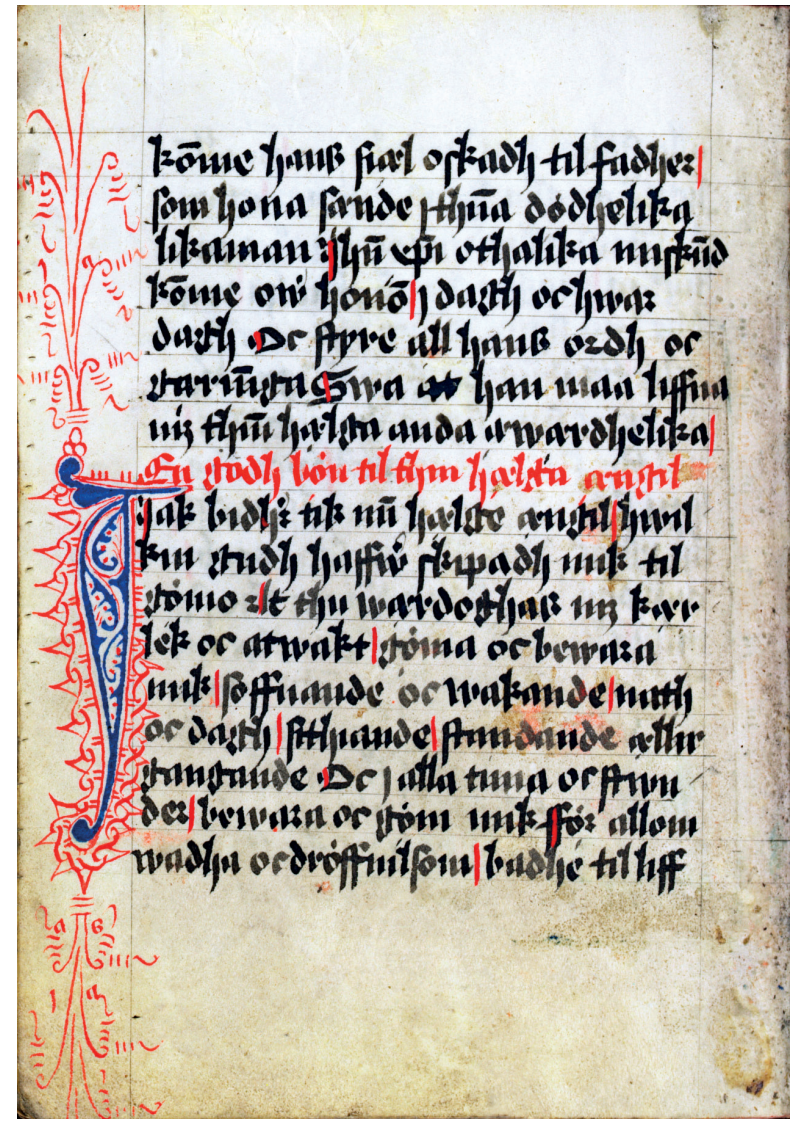

Bild 20. I den sirligt utformade marginaldekoren har bokmålerskan/skriverskan fogat in sina (a s) och den troliga ägarinnans initialer ( $i$ a) i rankverket. För det ovetande ögat kan de vara svårupptäckta. KB A 43f. 159v. Beskuren. Foto Jens Gustavsson, $K B$.

212 Anna Svensdotter var verksam på folio 3v-32v, 34r-43r, 59r-189v.

213 T.ex. folio 133v, se http://www.alvin-portal.org/alvin/imageViewer.jsf?dsId=ATTACHMENT0211\&pid=alvin-record\%3A184919\&dswid=-4948.

214 UUB Sv rar 10:90 folio 114v är delvis beskuren men ett $p$ syns i marginaldekoren. Hedström 2009 s 505 behandlar skrivarinitialerna i C 68. 


\section{Marginaldekorer och dekorerade initialer}

Det är främst detaljutförandet i filigraninitialerna och deras marginalrankor som kan användas för attribuering av bokmåleriet. På så vis kan man gruppera ytterligare handskrifter och jämföra med skriverskorna. Anna Germundsdotter illuminerade förmodligen hela C 458 och så gjorde även Christina Hansdotter (Brask) i C 12, C 442, C 443, Berlin Germ fol $726^{215}$ och ett finskt fragment (Helsingfors TH AA 129). Christina illuminerade troligen även hela A 4, men hon skrev bara den första delen.

Genom detaljlikheterna går det att gruppera samman A 3, A 12, B 70a, T 229, MPO Fr 27983 - 84, C 470 samt den inledande initialen i C 431. Dessa sju handskrifter innehåller text av tre redan nämnda skriverskor: Anna Germundsdotter, Katarina Johansdotter Gudmundi, ${ }^{216}$ Christina Hansdotter (Brask) samt ytterligare en eller två skriverskor. ${ }^{217}$ Trots att Christina skrev merparten av C 470, förefaller det som om hon inte dekorerade den. Istället överlät hon det till den som utförde dekoren i de andra handskrifterna i gruppen (se bilaga 1). ${ }^{218}$ Gruppen är homogen i stilen och målad med säker hand. De penntecknade anfangerna har mjuka yttre vågformer med lätt uppåtriktade toppar och C-formade avslut på marignalstjälkarna. Om det är skriverskan som själv utfört anfangerna i första delen av A 3 (f. 1-80, 149-156) går det möjligen att ringa in namnet även på bokmålarinnan, nämligen Katarina Johansdotter Gudmundi. ${ }^{219}$

Vid ett första påseende kan även A 1 (Bild 21.) och A 2 tyckas passa in i den aktuella gruppen med A 3 och A 12 m.fl., och det finns vissa gemensamma drag i dessa praktfulla handskrifter. Utformningen av de vågformade kanterna längs med anfangernas yttersidor uppvisar emellertid en tydlig skillnad eftersom vågtopparna i A 1 och A 2 hänger nedåt istället för uppåt. A 3 m.fl. har uppåtriktade toppar och är således utförda av en annan hand. ${ }^{220}$ (Bild 22.) Dateringen av handskrifterna A 1 och A 2, (1526 respektive 1534) gör dem till de yngsta i hela den bevarade handskriftsproduktionen från Vadstenasystrarna. När de skapades hade både Christina Hansdotter (Brask) och Katarina Johansdotter Gudmundi avlidit. Båda levde dock när den 1518 daterade C 458 skapades, vilken stilistiskt hör till samma grupp som A 1 och A 2. C 458 har Anna Germundsdotters initialer i rubriken på folio 33v. ${ }^{221}$

215 Berlin, Staatsbibliothek zu Berlin, ms Germ. Fol. 726.

216 Katarina Johansdotter Gudmundi. Hon var dotter till Gudmund Johansson och förekommer i källorna under båda patronymikon. Se Hedström 2009 s 65.

217 KB A 3: AG = fol. 81-93, 95-139. KG = fol. 1-80, 149-156. Se bilaga 1.

218 KB A 3 se https://www.manuscripta.se/ms/100203, A 12 se https://www.manuscripta.se/ $\mathrm{ms} / 100211$.

219 Resten av A 3 är kopierad av två andra systrar, och där används en dekortyp som saknar vågtandning, men har sammanlänkade långa blå-röda marginalstavar och tunna parallella tvärstreck på de tunt tecknade marginalspröten.

220 Det är också skillnader i utformningen av marginalsprötens sammansättningar och krokarna i deras avslut. Se https://www.manuscripta.se/ms/100203.

221 http://www.alvin-portal.org/alvin/imageViewer.jsf?dsId=ATTACHMENT-0045\&pid=alvinrecord\%3A116064\&dswid=2130. 


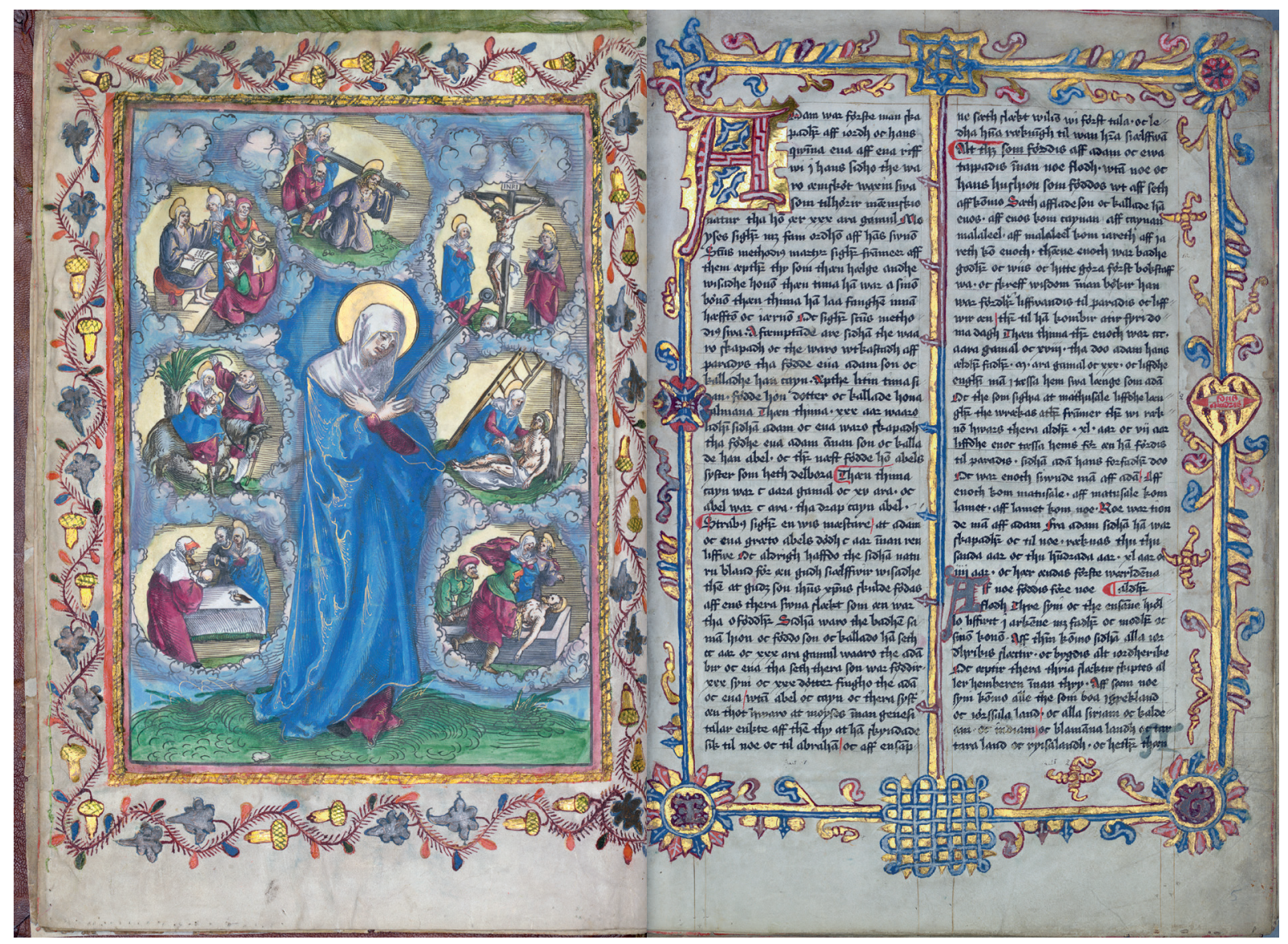

Bild 21. Det inledande uppslaget i A 1 visar ett färglagt tryck av den tyske konstnären Niklas Stör, inramad av en påkostad slingrande ekranka. På den motstående boksidan inramas de båda textspalterna av rikt dekorerade gyllene marginalstavar. Här finns både knutverksornamentik och växtelement. I den högra marginalstaven har ett särat hjärta infogats, försett med texten fons amoris. I de båda nedre rundlarna ses initialerna I och T, syftande på den som sponsrat den påkostade volymen, Ingegerd Torstensdotter från Lödöse. Hennes roll framkommer av kolofonen på folio 253r. KB A 1f. 0-1r. Mått ca $30 \times 43 \mathrm{~cm}$. Foto Jens Gustavsson, KB.

Både A 1 och C 458 uppvisar en alltigenom enhetlig skriftbild och dekorstil. A 2 har visserligen samma dekorstil, men vissa detaljer i skriftbilden skiljer sig åt mot dem. ${ }^{222}$ Syster Anna var verksam i klostret 1489-1538, och det är alltså fullt möjligt att hon utfört både dekor och skrift i A 1 (1526) och C 458 (1518), men i så fall har hon troligen inte kopierat texten i A $2 .{ }^{223}$

I likhet med A 3 och A 12 m.fl. har lektionariet B 70a och bönboken T 229 uppåtriktade vågtoppar medan vi konstaterade att C 458, A 1 och A 2 har nedhängande. ${ }^{224}$ Dekoren med nedhängande vågtoppar på de stora filigrananfangernas utsi-

222 Bokstaven g står på och hänger ned under linjen i A 1 och C 458, men står mer ovanför linjen i A 2.

${ }^{223}$ Den som kopierade KB A 2 kopierade troligen även UUB C 469. Det förekommer i litteraturen att KB A 1 och A 2 tillskrivs samma skrivare, men jag är tveksam.

${ }^{224} \mathrm{C} 458 \mathrm{f} 6 \mathrm{r}, 13 \mathrm{v}, 30 \mathrm{v}, 33 \mathrm{v}$ se https://www.alvin-portal.org/alvin/view.jsf?dswid=2130\&search Type $=$ EXTENDED\&query $=\mathrm{C}+458 \& \mathrm{aq}=\% 5 \mathrm{~B} \% 5 \mathrm{~B} \% 7 \mathrm{~B} \% 22 \mathrm{~A} \_\mathrm{FQ} \% 22 \% 3 \mathrm{~A} \% 22 \mathrm{C}+458 \% 22 \% 7$ D\%5D\%5D\&aqe=\%5B\%5D\&af=\%5B\%5D\&pid=alvin-record\%3A116064\&c=3\#alvinrecord\%3A116064. 

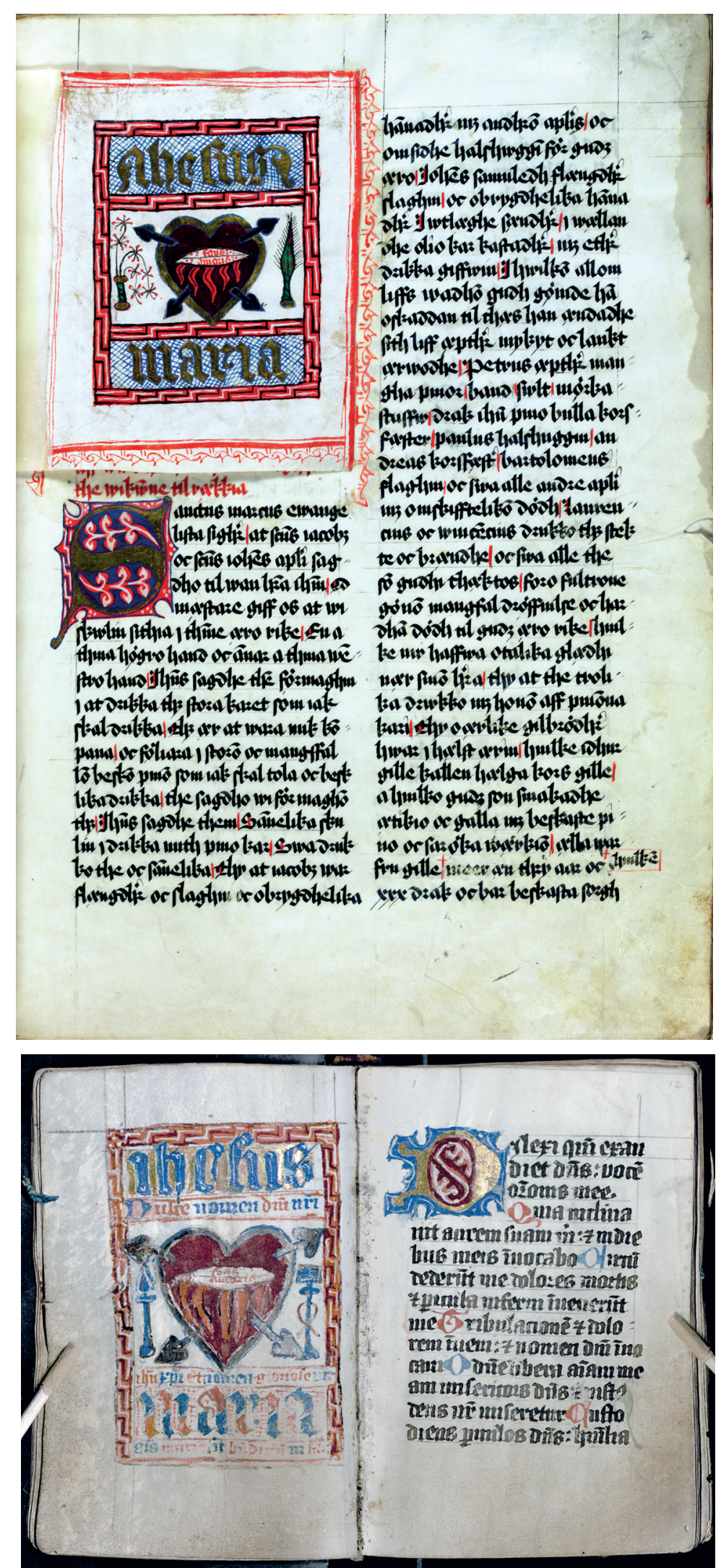

Bild 22. Båda handskrifterna $A 3(\mathrm{ca} 27 \times 38 \mathrm{~cm})$ och C 443 (ca $13 \times 18 \mathrm{~cm}$ ) har framställningar av det sårade hjärtat med pinoredskapen, inramat av namnen Jesus och Maria. I såret kan man läsa orden fons amoris. I A 3 finns en text bakom bilden och den är därför infogad som bortvikbar. I C 443 har den målats direkt på pergamentet $i$ handskriften. Foto Jens Gustavsson, KB, respektive (C) UUB. 
dor visar sig förekomma bara i ytterligare två handskrifter: C 469, C $473 .{ }^{225}$ B 70a är daterad året före C 458 (1517) och visar upp samma skriftbild som denna, dvs. Anna Germundsdotters. Men eftersom initialdekoren i B 70a har uppåtriktade vågtoppar istället för nedåtgående, är det inte troligt att samma person dekorerat både den och C 458. ${ }^{226}$ Dekoren i B 70a har vidare likheter med dekoren i T 229 och A 12. Även i A $12^{227}$ liknar emellertid skriften C 458 (Anna G), medan dekoren har utförts på samma sätt som i B 70a, T 229, Ps 12 m.fl., dvs. av Katarina Johansdotter Gudmundi. ${ }^{228}$

Den delvis snåriga genomgången av dekor och skrift ovan visar att Vadstenasystrarna inte hade specialiserade dekorationsmålare, utan att en skriverska huvudsakligen dekorerade sin text. Det innebär att hon kunde förse texten med dekor som anspelade på innehållet, i vissa fall som en mnemoteknisk aspekt, eller infoga sina egna initialer i dekoren. På så vis kunde hon vädja om förbön.

Kombinationen av skrift- och dekoranalys har visat på ytterligare möjligheter att identifiera och attribuera skrivarhänder i det komplexa materialet från Vadstena kloster. Analysen visar att det fanns grupper av skriverskor som arbetade med samma bokverk, men att de i princip ändå illuminerade de egna textavsnitten. Undantagen är få. En skrivande nunna kunde därför infoga dekorelement som understödde textinnehållet. Det innebär att t.ex. de hjärtan som förekommer i marginaldekorerna kan vara en medveten anspelning på Kristi och jungfru Marias kärleksgärning. De kan då fungera på samma betydelsebärande sätt som detaljerna i vissa av broderierna, ett bildbruk som vi återkommer till i nästa kapitel. Några av skriverskorna var förvisso mer drivna när det gällde skrift än dekor, och tvärtom, men den estetiska kvalitetsaspekten förefaller inte ha varit prioriterad. De böcker som systrarna tillverkade var till för att användas i deras dagliga andaktsliv, och i likhet med övrig verksamhet till för att främja den eviga saligheten och inte den estetiska njutningen.

\section{M-rankor och hjärtan}

Ytterligare en klart identifierbar dekorgrupp i Vadstenamaterialet är några handskrifter där marginalstavarna utgörs av m-formade bågar som staplas på varandra i rader. Handskrifterna kommer från både systrarnas och brödernas boksamling och spänner över en så pass lång tid, att de inte kan förknippas med en enskild person. Den äldsta av handskrifterna som visar denna dekor skrevs av broder Thorkel Elofsson (1467-1513) när han var utsänd till Norge för att bistå det birgittinska

225 Den förvisso snarlika C 469 kan dateras till 1508-1526, men det finns skillnader i skriftbilden mellan C 469 och t.ex. A 1 som gör det svårt att attribuera dem till samma skriverska.

226 https:/www.alvin-portal.org/alvin/view.jsf?dswid=-3033\&searchType=TEXT\&query=B+70a \&aq=\%5B $\% 5 B \% 7 B \% 22 \mathrm{~A} \_F Q \% 22 \% 3 \mathrm{~A} \% 22 \mathrm{~B}+70 \mathrm{a} \% 22 \% 7 \mathrm{D} \% 5 \mathrm{D} \% 5 \mathrm{D} \&$ aqe $=\% 5 \mathrm{~B} \% 5 \mathrm{D} \& \mathrm{af}=\% 5$ B\%22ARCHIVE_ORG_ID_facet\%3A13\%22\%5D\&pid=alvin-record\%3A12532\&c=3\#alvinrecord\%3A12532

227 KB A 12 se https://www.manuscripta.se/ms/100211.

228 Skriften i Linköpingshandskriften T 229 liknar i hög grad Anna Germundsdotters (C 458), men en intressant skillnad är att de så kallade tironska sjuorna (ett "och”-tecken) i T 229 inte är utförda på samma sätt som i C 458. 


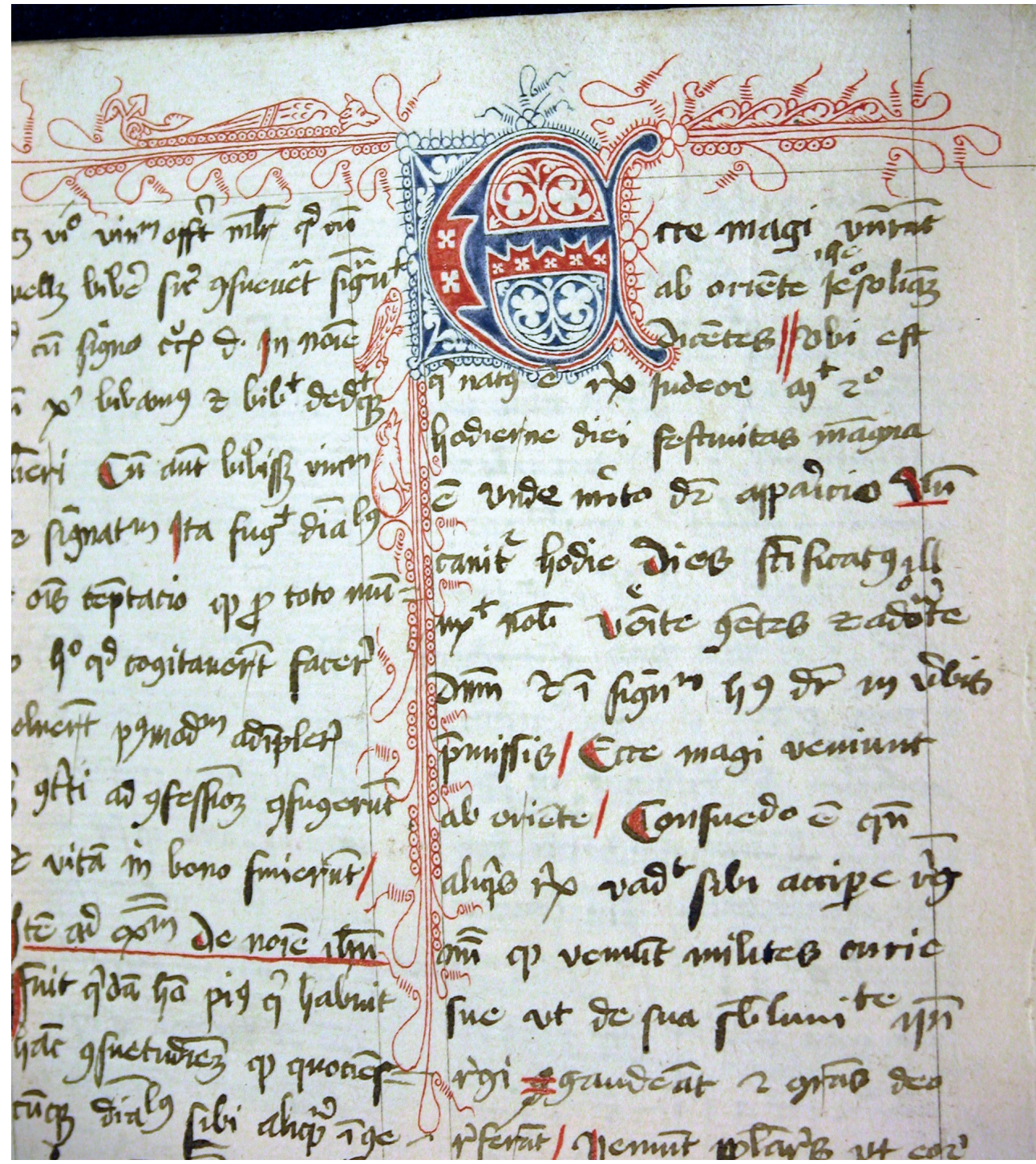

Bild 23. Detalj ur den predikohandskrift (av Johannes Herolt Discipilus) som kopierades av Thorkel Elofsson under hans vistelse i det norska birgittinklostret Munkaliv på 1470-talet. Texten ligger ibland ovanpå dekoren, vilket visar att den löpande texten är skriven efter att dekoren har utförts. Marginaldekorens långa röda stavar pryds av m-formade krokar. UUB C 278 f $68 v$. (C) UUB.

klostret Munkaliv i Bergen åren 1467-71. ${ }^{229}$ Han skrev där C 278 med predikningar av Johannes Herolt. (Bild 23.) Den införlivades sedan i brödernas bibliotek med signum $C V$ xvi. Handskriften är både daterad och lokaliserad i Norge av broder Thorkel på folio 364r. ${ }^{230}$ Texten är så väl avpassad till dekoren att den förefaller ha varit förberedd för att fyllas med just denna predikosamling. An-

229 Klostret brändes i en konflikt mellan staden och Hansan 1455 och klosterfolket tog sin tillflykt till cisterciensklostret på Huvudöya utanför Oslo fram till 1478, då man flyttade tillbaka till Bergen.

230 MHUU bd 31990 s 273. 
fangerna passar utmärkt väl ihop med textflödet. Normalt sett skrev man texten först och sedan gjordes bokmåleriet på de ytor som reserverats för det. Eftersom skriftens bruna bläck på ett flertal ställen har skrivits ovanpå dekoren har en omvänd produktionsgång praktiserats i detta fall. Måleriet är utfört med tunna säkra linjer av en rutinerad bokmålare, kanske till och med från ett tidigare sekel. Den något gammalmodiga stilen på bokmåleriet skulle kunna ha sin förklaring i att en äldre förberedd handskrift fanns att tillgå för just denna text. Munkaliv hade en förhistoria som benediktinkloster innan det konverterades till birgittinkloster 1426. I marginalerna i C 278 finns långa rankor som har formen av minuskel-m som staplats över varandra. Det är denna egenhet som sedan dyker upp i andra Vadstenahandskrifter. Torkels C 278 är alltså den äldsta av dem, skapad mellan 1467 och 1471, ${ }^{231}$ medan den yngsta tycks vara en Cantus sororumhandskrift som två norska nunnor tog med sig till Vadstena när de 1531 flydde undan den norska reformationen, den tidigare nämnda C 448. ${ }^{232}$ Ytterligare handskrifter av varierande innehåll men med snarlik dekor är A 32 (Revelationes bok V-VIII, bild 25), C 161 (tre teologiska texter), ${ }^{233}$ C 456 (psalterium), C 471 (bönbok), C 485 (korbok) och E 9068 (bönbok). Det finns också några

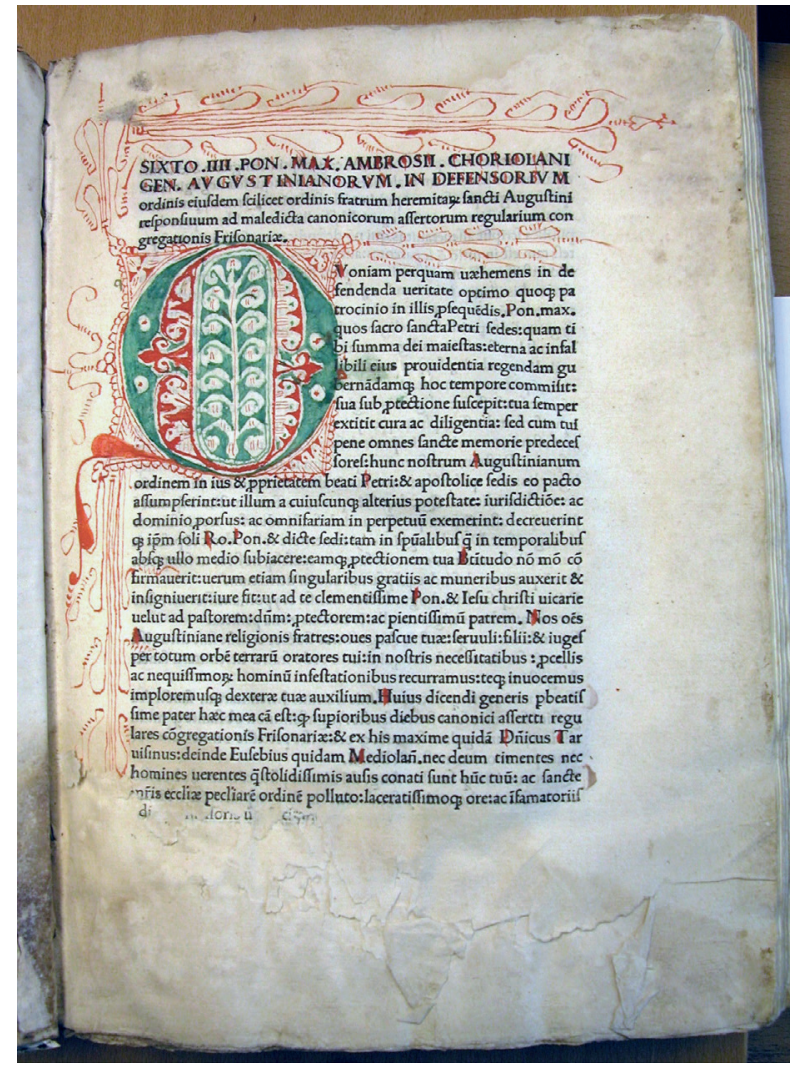

Bild 24. Första sidan ur en inkunabel frän Vadstenabrödernas bibliotek. Den långa titeln lyder Defensorium ordinis eiusdem scilicet ordinis fratrum heremitaR sancti Augustini responsiuum ad maledicta canonicorum assertorum regularium con gregationis Frisonariae. Den är tryckt $i$ Rom 1482 men har fätt dekoren utförd $i$ Vadstena. Samma typ av m-formad dekor som $i$ UUB C 278. UUB Ink 33:122 (ca $27 \times 38 \mathrm{~cm}$ ). (C) UUB. tidiga tryckta böcker från Vadstena som har försetts med samma dekortyp, inkunablerna UUB Ink 33: 38 (Bibel, tryckt 1479), Ink 33: 76 (Thomas Aquino, tryckt i Venedig 1480), Ink 33: 122 (Ambrosius de Cora, tryckt 1474 ? $)^{234}$. (Bild 24.) De tryckta böckerna har förvärvats från andra länder och med stor sannolikhet dekorerats inom klostrets murar. Detta gäller sannolikt även C 161 och A 32 som har signum från brödernas bibliotek (signum Cv $7^{u s}$ resp. $\left.E 2^{\circ} I^{u s}\right)$. C 161 är enligt folio 35v tillverkad i Konstanz och förvärvades möjligen av bröderna i samband med konsiliet där 1414-18. A 32 är svårare att datera, men hör

\footnotetext{
231 MHUU bd 31990 s 273.

232 https://www.alvin-portal.org/alvin/view.jsf?dswid=-4948\&searchType=EXTENDED\&query $=\mathrm{C}+448 \& \mathrm{aq}=\% 5 \mathrm{~B} \% 5 \mathrm{~B} \% 7 \mathrm{~B} \% 22 \mathrm{~A} \_\mathrm{FQ} \% 22 \% 3 \mathrm{~A} \% 22 \mathrm{C}+448 \% 22 \% 7 \mathrm{D} \% 5 \mathrm{D} \% 5 \mathrm{D} \& \mathrm{aqe}=\% 5 \mathrm{~B} \% 5$ $\mathrm{D} \& \mathrm{af}=\% 5 \mathrm{~B} \% 5 \mathrm{D} \& \mathrm{pid}=\mathrm{alvin}-\mathrm{record} \% 3 \mathrm{~A} 116080 \& \mathrm{c}=2 \#$ alvin-record\%3A116080.

233 Mattaeus de Cracovica, Petrus de Alliaco, Gilbertus Minorita: Distinctio passionis per horas, Dialogus rationis et conscientiae de crebra communione, Meditationes super septem psalmos paenitentiales, Summa de vitiis et virtutibus.

234 Fredriksson 1996 s 45, 63.
} 


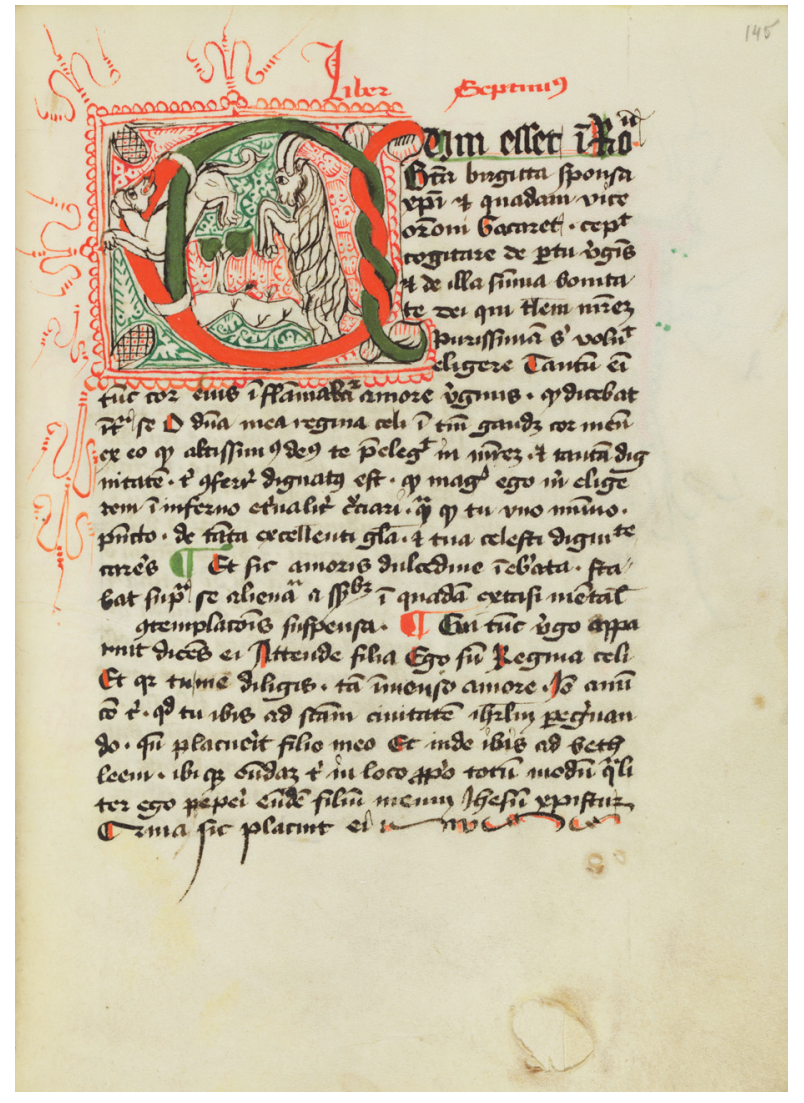

Bild 25. En initial med en hund och en bock inleder bok sju $i$ Birgittas Himmelska Uppenbarelser. Initialen är en av fä figurativa framställningar $i$ klostrets handskrifter. Runt den historierade initialen skjuter det ut $m$-formade rankor $i$ de intilliggande marginalerna. KB A 32 f. 145 r (beskuren).

Foto Jens Gustarsson, KB. hemma i 1400-talets Vadstenaproduktion. (Bild 25.) Bönböckerna (C 471, E 9098), psalteriet (C 456) och korboken (C 485) med den aktuella dekoren både tillverkades och användes i nunnornas del av klostret, men är svåra att datera exaktare än till sent 1400-tal/tidigt 1500-tal. Christina Hansdotter (Brask) har medverkat som skriverska i C 456 (folio 51-143), men inte utfört dekoren. Övriga skrivare i C 456 är inte identifierade och inte heller skriverskorna i C 471, C 485 och E 9068, trots att så många som nio olika händer kan spåras i den sistnämnda. Stilistiskt sett ligger dekoren i den norska Cantus sororum C 448 närmast Thorkel Elofssons C 278, men bönboken är mindre stringent utförd. Båda dessa verk med norsk anknytning kombinerar dessutom kursiv stil med bokmåleriet, vilket är ovanligt.

Betydligt prydligare skrivna än broder Thorkels bok är C 471, C 456 och delar av E 9068. E 9068 och C 456 har samma dekormålare, men inte samma skrivare. C 456 har sannolikt kopierats av tre olika skriverskor, varav den ena alltså är Christina Hansdotter (Brask) (f. 51-143). ${ }^{235}$ Den första handen i C 456 (f. 1r-47v) påträffas även i C 471 (f. 21r-30v, 159r-182v) och C 485 (f. 1r-42v). Skriverskan som verkade i både C 456, C 471 och C 485 använde en m-formad dekor som jämfört med de andra har ett något skirare utförande med mer luftighet och mindre tätt mellan m:en. Samma karaktär i dekoren har också en tryckt bibel från Vadstenabiblioteket, den nyssnämnda Uppsalainkunabeln Ink 33:38. ${ }^{236}$ Betydligt mer tätt dekorerade av m-formade marginalstavar är A 32, C 161 och bönboken E 9068. ${ }^{237}$ Det är också på de boksidor som den tredje handen har skrivit som de m-formade marginaldekorerna förekommer. ${ }^{238}$ Visserligen har Christina Hansdotter (Brask) varit inblandad i kopieringen av några av handskrifterna med den aktuella m-dekoren, men spåren leder inte till henne. Hon har som nämnts en annan stil. Den som målade den skira dekoren vid anfangen på

235 C 456: I 1r-47r, II 47r-50v, III 51r-143r. Hand I samma som C 471 hand II.

236 Förvärvad mellan 1490 och 1531, Fredriksson 1996 s 55. Tryckt i Nürnberg 1479 enligt Libris. Bibliotekssignum ej känt.

237 E 9068 Hand I folio 1r-5v, 14r-28r, 29r-30r, 73r-83v, 88r-99v, 116r-117r. Kanske är det samma skrivarhand som hand A 3: III, Berlin Theol lat 71: II, C 456: I, och antingen hand II eller VI i Gießen 881? Ingela Hedström har enligt muntlig uppgift 2018 en annan attribuering och anser att skrivare A3: III = A 82, men inte identisk med E 9068: I.

238 Folio 3r, 29r, 88r och 117r. 
folio 32r i E 9068 har istället en stil som påminner om C 452 och Lund Mh 21, men ändå utförd mindre stringent och dessutom betydligt senare än de. ${ }^{239}$ Ytterligt proffsig dekor och skrift har Cantus sororum C 444 och delar av C 442. De har $\mathrm{m}$-former i några av marginalerna, men blommar inte alls ut $\mathrm{i}$ långa slingor som exempelvis i A 32, C 456 och E 9068. Eftersom Christina Hansdotter (Brask) är den andra handen verksam i C 442 kan den åtminstone dateras till hennes långa professtid, 1459-1520.

Samma täta karaktär på marginaldekoren med minuskel-m som i A 32 m.fl. ses också i ett par av de ovan nämnda tryckta böckerna från Vadstenabrödernas samling, Ink 33:76 och Ink 33:122 (bild 24), tryckta 1474 respektive 1482. ${ }^{240}$ Hur snart därefter som de kan ha införlivats i klostrets bibliotek är oklart, men det kan ha skett inom bara några år, eftersom flera av bröderna var ute på bland annat Romresor under denna period. ${ }^{241}$ Att Revelationeshandskriften A 32 härstammar från brödernas bibliotek visar alltså dess bibliotekssignum, och att detta dessutom är treställigt tyder enligt latinisten Anna Fredriksson på att den förvärvades under senare delen av 1400-talet. ${ }^{242}$ Till skillnad från A 32 har C 161 som sagt inte skrivits i klostret utan inköpts i Tyskland redan i början av 1400-talet. ${ }^{243}$ Dekoren ger emellertid intryck av att huvudsakligen vara senare tillagd. Det röda bläcket som använts i anfanger och marginalrankor är inte av samma nyans, vilket de oftast är när de är utförda samtidigt. Den omgivande "bubbeldekoren” är i en rödare nyans, mer i överensstämmelse med marginalrankan. På flera ställen i handskriften kan man se att marginaldekoren och "bubblorna" som omger de gröna eller röda lombarderna krockar med anfangernas form och stundtals ligger den tydligt ovanpå textens bläck. Inramningen av den inledande B-initialen på folio $1 \mathrm{r}$ har även fått anpassas efter utrymmet. Utrymmesbristen gör att det saknas "bubblor" undertill. Det verkar således som om den ursprungliga dekoren kompletterats i ett senare skede.

De m-formade marginalrankorna skulle kunna vara en rent estetisk preferens som några av skriptoriets medarbetare valt att favorisera, kanske under en begränsad period. Det är emellertid inte en dekor som kan knytas till bara en specifik skrivare. Dateringen av handskrifterna och böckerna visar att det handlar om flera decennier kring sekelskiftet 1500, inte bara en kort period. Att man väljer att dekorera även inköpta handskrifter och böcker med m-dekoren säger kanske också något om värderingen av utformningen?

239 Lund Mh 21 skrevs av Vadstenabrodern Johannes Johannesson, verksam i klostret 1416-46. Samma stil har C 452, skriven delvis av samme broder som Lundhandskriften, men dekoren i C 452 är placerad på folio $25 \mathrm{r}-72 \mathrm{v}$, dvs. den del som skrevs av den annan skrivare, inte Johannes. MHUU bd 51992 s 142 .

240 UUB Ink 33:76 Thomas Aquino De veritate catholicae fidei contra errores infidelium sive Summa catholica fidei. Tryckt i Strassburg 1474. Attribueras till Vadstena, bibliotekssignum ej känt. Ink 33:122 Ambrosius de Cora Defensorum ordinis heremitarum S Augustini. Tryckt i Rom 1482. Förvärvad i Vadstena 1490-1531, Fredriksson 1996 s 55. Vadstenasignum: F 3 $12^{u s}$. Tillhörde Filip Ingmarsson.

241 Bröder anlände hem till Vadstena från bl.a. Rom 1488 enligt DV 879, och 1506 enligt DV 982. Fler resor till Rom nämns i diariet under 1500-talet.

242 Fredriksson 1997 s 20.

243 Inskrift på folio 35v daterar den till 1417. 

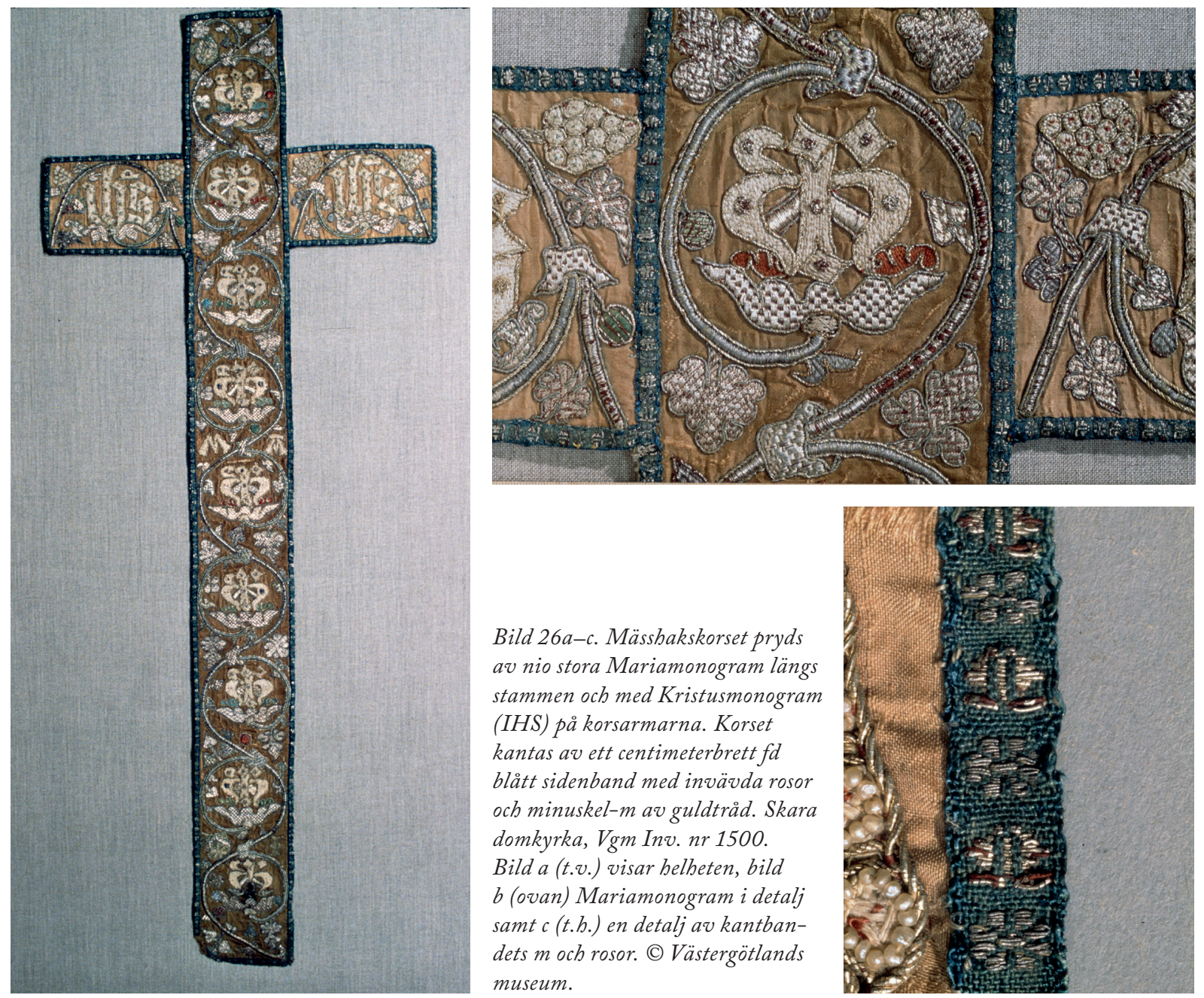

Bild 26a-c. Mässhakskorset pryds av nio stora Mariamonogram längs stammen och med Kristusmonogram (IHS) på korsarmarna. Korset kantas av ett centimeterbrett fd blått sidenband med invävda rosor och minuskel-m av guldtråd. Skara domkyrka, Vgm Inv. nr 1500. Bild a (t.v.) visar helheten, bild $b$ (ovan) Mariamonogram i detalj samt c (t.h.) en detalj av kantbandets $m$ och rosor. (C) Västergötlands museum.

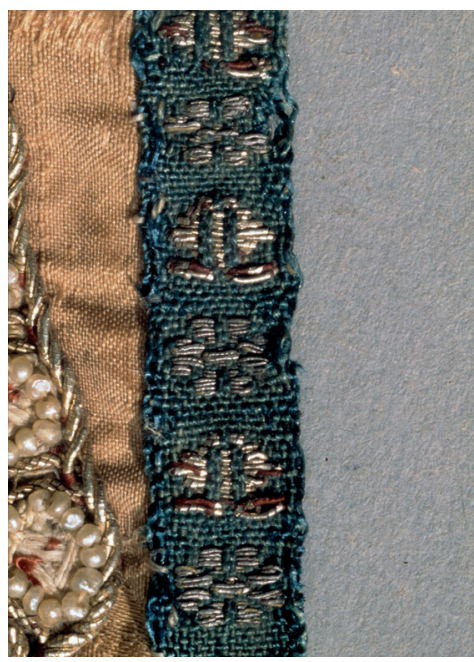

Det finns en textil parallell till handskrifternas m-formade marginalrankor på ett mässhakekors och en besättningsbård (s.k. parura) från Vadstena. Bården finns nu i Vadstena klostermuseum och korset tillhör Skara domkyrka (nu i Västergötlands museum). (Bild 26.) De broderade föremålen tillverkades av Vadstenanunnorna inom samma tidsperiod som de $\mathrm{m}$-formade marginaldekorerna i handskrifterna skapades. Längs med mässhakskorsets hela stam finns nio stora Mariamonogram, och på vardera av de båda korsarmarna ses ett Kristusmonogram (IHS). ${ }^{244}$ Monogrammen är infogade in en slingrande vinranka och längst upp finns en liten vapensköld. Vapnet kan enligt Estham troligen hänföras till Skarakaniken Magnus Ambjörnsson, vars syster Ingrid/Ingegärd förmodas ha ägt den tidigare diskuterade bönboken A 43. ${ }^{245}$ Runt kanten på mässhakskorset och på den högra sidan av besättningsbården sitter ett centimeterbrett vävt band som dekoreras av minuskel-m omväxlande med sexud-

${ }^{244}$ Mariamonogrammet finns även på undersidan av foten på en kalk Maribo domkyrka (Dk), se https://www.wikiwand.com/no/Maribo_domkirke\#/Inventar.

245 Estham 1991 s 44-47, densamma 1986 s 379-80. Släkten Store har blå botten och silverstjärna/ sparre, men Drake av Ingtorp har guld mot blå botten. Färgerna syns inte i reproduktionerna. 
diga rosor. Rosorna och m:en är av guldtråd mot blå sidenbotten. Det finns således en tydlig anspelning på jungfru Maria i detta mässhakekors. Det är till och med så att Maria-tematiken nästan är mer påfallande än Kristusreferenserna, trots att det är ett kors. Med tanke på den starka Mariaspiritualitet som genuint präglar Birgittinorden är referenser till jungfru Maria ett givet inslag även i det visuella materialet. Referenser till Maria kan uppfattas i många olika former. Hon är t.ex. rosen, liljan, pärlan, havets stjärna, enhörningsfångaren och så vidare. Alla dessa anspelningar finns i Vadstenasystrarnas bokliga och textila arv. Att, på samma sätt som i kantbandet, skriva minuskel-m som Mariareferenser i böckernas marginaler, ligger nära till hands. Jungfru Maria var systrarnas förebild i Kristusefterföljelsen. De gick i hennes fotspår och allt de gjorde inramades och förevisades av henne: tidebönernas olika dagliga teman, Marias vandring i spåren efter Kristi passionsvandring, Marias tilltal till Birgitta i Uppenbarelserna, allt präglades av jungfru Maria. ${ }^{246}$ Ibland består referenserna av bara ett $\mathrm{M}$, ibland av Mariamonogram och andra gånger av bokstavskombinationer som anspelar på exempelvis bönen Ave Maria eller både Maria och Birgitta. ${ }^{247}$

I några fall ledsagas handskrifternas m-dekorer av hjärtformade hängen. I Christina Hansdotters (Brask) initialer är det stundtals ett hjärta som formar avslutningen nedtill på initialdekoren, som exempelvis i bönboken E 9068. (Bild 27.) Detta hjärttema i kombination med Mariaanspelningarna går att se på flera håll i Vadstenamaterialet. Ett par broderier från dotterklostret i Nådendal (Finland) är översållade av Maria-referenser, bland annat hjärtan. ${ }^{248}$ Ursprunget till denna koppling mellan Maria och hjärtat visar också på en koppling till Kristi lidande. Marias kärlek till sonen skulle förvisso kunna symboliseras av ett hjärta, men i det teologiska sammanhanget syftar hjärtat också på den ömsesidiga djupa kärleken mellan Maria och Kristus. Några av hjärtana innehåller också Kristi sår, som i C 443 (bild 22b), vilket ger en koppling mellan Marias lidande inför sonens lidande, "hans hjärta var mitt hjärta" som Maria vittnar om för Birgitta i Uppenbarelserna. ${ }^{249}$ Därför flankeras bilden av Marias sju smärtor i A 1 (bild 21) av ett sårat hjärta i marginalen mittemot och därför kan även inskriften inuti hjärtat, fons amoris, syfta på både Marias kärlek och den självutlämnande Kristuskärleken, samt Guds kärlek till människorna när han sände sin son att dö för världen. Både minuskel-m:en och de små hjärtana i

246 Se Härdelin, Alf, I Kristi och Marias spår: om stationsandakter i Vadstena kloster: textutgåvor och analyser, Runica et mediævalia, Stockholm, 2003.

247 En del tolkningar av infogade initialer som syftande på brodöser/skriverskor är troligen felaktigt uppfattade referenser till Maria, se diskussion hos Räsänen 2013 s 109-135 (isht s 129ff).

248 De förvaras i Nationalmuseet i Helsingfors. Bild se t.ex. https://stor.systeemi.net/thumbnail. php?pic=uimgc/img_5423664_ee5b08c29d93b19669c74148faa92866.jpg\&w=1024\&sq=Y\&b=Y, https://www.google.com/search?client=firefox-b-ab\&biw=1530\&bih=829\&tbm=isch\&sa=1\&ei =ivoIXI2ICsWMmgXVi4SwBQ\&q=n\%C3\%A5dendal+broderi\&oq=n\%C3\%A 5 dendal+broder i\&gs_l=img.3...14515.17451..18796...0.0..0.51.639.16......0...1..gws-wiz-img.......0j0i67j0i5i30j0 i30j0i24.yoszY7WjFUM.

249 Sahlin, Claire, "'His heart was my heart.' Birgitta of Sweden's devotion to the heart of Mary", Heliga Birgitta - budskapet och förebilden. Föredrag vid jubileumssymposiet $i$ Vadstena 3-7 oktober 1991, KVHAA, Konferenser 28, red. Alf Härdelin, Mereth Lindgren, Stockholm 1993 s $213-$ 227. 

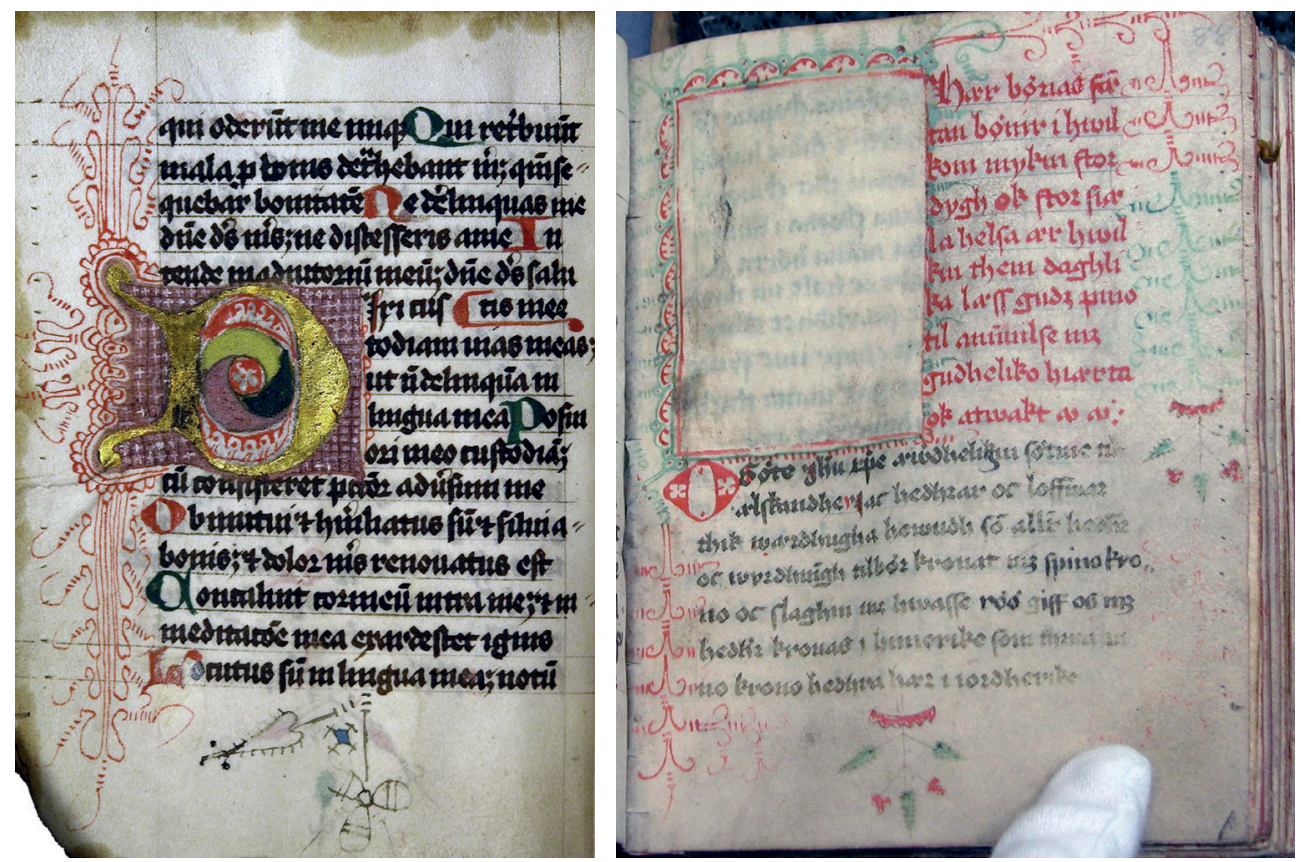

Bild 27. Två bönboksexempel från Vadstena på m-formade marginalrankor med hjärtformade hängen och stora initialer med rutiga fonder. A) UUB C $456 \mathrm{f} 43 \mathrm{v}, \mathrm{B}) \mathrm{RA} E 9068 \mathrm{f} 88 \mathrm{r}$. (C) UUB och förf.

marginalerna kan placeras in i den marianskt djupt präglade birgittinska fromheten. Att tolka dem som enbart dekorativa inslag, vore att förringa dem. ${ }^{250}$

Förutom de m-formade marginalerna har Uppenbarelsehandskriften A 32 ytterligare ett intressant inslag av bokmåleri, som är mycket ovanligt i Vadstenahandskrifterna. (Bild 25.) På folio 145r har den inledande bokstaven $\mathrm{C}$ utformats som en historierad initial. Det innebär att den har en figurativ framställning och inte enbart en dekorativ utformning. Det är en av mycket få figurativa initialer i Vadstenamaterialet överhuvudtaget. Den nio rader höga initialen inleder bok 7 av Birgittas Uppenbarelser, med orden "Cum esset..." I det röd-gröna C:et reser sig en raggig bock på bakbenen, jagande en vit hund som trasslat in sig i bokstavens vänstersida. I bakgrunden skymtar ett träd och lite markvegetation, och i de båda vänstra hörnsvicklarna ses kott-imiterande mönster. ${ }^{251}$ Bokens signum $\left(E 2^{\circ} 1^{u s}\right)$ avslöjar att den hört till brödernas boksamling men frågan om den är utförd av systrarna eller bröderna får lämnas öppen tills vidare.

250 Sandgren, Eva Lq, "Hearts of Love and Pain: Images for Devotion in Vadstena Abbey", Words and matter: the Virgin Mary in late medieval and early modern parish life, eds. J. Carlquist, V. Langum, Runica et Mediaevalia, Stockholm 2015.

251 På folio 32r och 213r finns 6-7 rader höga dekorerade initialer i samma stil och kulörer. 


\section{Miniatyrer och bildprogram i Vadstenahandskrifterna}

Uppenbarelsehandskriften A 32 är således en för klostret unik bevarad inhemsk produkt med sin figurativa initial. (Bild 25.) Figurmåleri är överhuvudtaget ett begränsat fenomen i de handskrifter som tillverkats i Vadstena. ${ }^{252}$ Antalet bevarade miniatyrer som målats direkt på pergamentet är ytterst få. Det förefaller som om man i Vadstenaskriptoriet företrädesvis limmat in eller sytt fast bilder i sina böcker istället för att måla dem direkt på pergamentet. Det finns endast ett fåtal undantag, som bönboken A 36 med en miniatyr av Nådastolen, Gregoriusmässan i Berlin Theol oct 71,253 Kristi sidosår med passionsredskap i A 80 (bild 15), den emblematiska bilden av det sårade hjärtat i C 443 (bild 22b) samt på fem ställen i bönboken C 68. ${ }^{254}$ Madonnabilden i A $43 \mathrm{f}$. 4v är däremot så noggrant fastklistrad att den kan förefalla målad direkt på boksidan, men i ena hörnet avslöjar limsläppet att det också är en inklistrad miniatyr, om än handmålad. ${ }^{255}$ Likaledes är den handmålade Gregoriusmässan i C 420 inklistrad i missalet. (Bild 46 nedan.) $)^{256}$

Att döma av de bevarade miniatyrerna och spåren efter några av de förlorade, använde systrarna gärna kolorerade tryck, träsnitt, som man importerat företrädesvis från Tyskland och Nederländerna. Ingegerd Ambjörnsdotters bönbok (A 43) är en mycket tydlig företrädare för detta med fem av sina sex bevarade miniatyrer av utländsk proveniens. ${ }^{257}$ Tryckta bilder har ingått även i A 1, A 3, A 12, C 12 och C 68. I de allra flesta fall har de infogade bilderna tyvärr gått förlorade. Miniatyrer som varit inklistrade har stundom avlägsnats helt och hållet och vad som finns kvar är limresterna och den handmålade ramen som omgett bilden. Att de i så stor utsträckning har försvunnit beror mestadels inte på att man använt dåligt lim, utan att någon senare avsiktligt avlägsnat dem. Ibland har även hela boksidor eller delar därav blivit utskurna och idag ser man bara ett hål i pergamentet eller resterna av en boksida i inre marginalen bredvid bindningen. Spåren av miniatyrerna vittnar om att det inte varit helt lätt att få dem att släppa från boksidan. Det finns också exempel på att bilder varit fastsydda i pergamentet med tråd, och därför försvunnit när tråden brustit. Kvar finns då raderna av nålhål i pergamentet. ${ }^{258}$ Nålhålen kan ibland härstamma från förlorade illuminationsskyddande "silkesgardiner", om de är placerade i närheten av en illumination och längs med boksidans marginal. Men

\footnotetext{
${ }^{252}$ I brödernas bibliotek fanns däremot ett antal illuminerade verk som tillverkats utomlands, se kapitel 3 nedan.

253 https:/digital.staatsbibliothek-berlin.de/werkansicht?PPN=PPN859357414\&PHYSID= PHYS_0256\&DMDID=DMDLOG_0033\&view=overview-toc [2020-06-10] eller betaversionen https://digital-beta.staatsbibliothek-berlin.de/werkansicht?PPN=PPN859357414 \&PHYSID=PHYS_0256\&DMDID=DMDLOG_0033 [2020-06-10].

254 Nålhål efter stygn i kanten av förlorade bilder i C 68 se folio 49, 50, 86, 145, 146 och 148.

255 Bild se https://www.manuscripta.se/ms/100223.

256 Bild se http://www.alvin-portal.org/alvin/imageViewer.jsf?dsId=ATTACHMENT-0024\&pid =alvin-record\%3A193383\&dswid=1843. En framställning av samma motiv ingår även på folio $123 v$ i Vadstenabönboken i Berlin, se fotnot 105 ovan.

257 Braaten 2006 s 52-54.

258 T.ex. i KB ms Rålamb 4 in $8^{\circ}$ folio 27.
} 
det finns alltså exempel på att synålshålen istället löper runt hela bildens utrymme, vilket betyder att den varit fastsydd. ${ }^{259}$ Exempel på förlorade inklistrade bilder möter på ett flertal sidor i Birgitta Andersdotters bönbok (A 80) medan det i Gävlebönboken är flera initialer som skurits bort, samt ett helt blad. ${ }^{260}$

Tack vare att de flesta av de förlorade bilderna lämnat tydliga fysiska spår efter sig kan man inte bara se var i böckerna bilderna en gång varit infogade utan också utläsa vid vilka texter de placerats. Det visar sig också att det är många av nunnornas bönböcker som haft mer eller mindre omfattande bildprogram. (Se bilaga 2.) Vissa har haft enstaka bilder och andra har haft ett tiotal eller fler. De tre stora handskrifterna A 1, A 2 och A 3 har haft begränsade bildprogram men har ändå förlorat fyra bilder sammanlagt. ${ }^{261}$ Bönboken A 12 förefaller komplett med sina tre inklistrade tryckta bilder medan A 36, C 443 och Berlin Theol lat 71 har vardera kvar en av sina två miniatyrer. A 81 och E 9068 har spår av tre miniatyrer var. Gießen 881 tycks ha haft två eller tre miniatyrer. A 80 och C 12 uppvisar betydligt mer omfattande bildprogram som gått förlorade medan A 43 har kvar sju av nio ursprungliga miniatyrer $^{262}$ och C 68 har kvar sju av de ursprungligen sjutton miniatyrerna. ${ }^{263}$

\section{Bildprogrammen i nunnornas bönböcker}

Den av Christina Hansdotter (Brask) skrivna tideboken C 12 har tre bevarade små träsnitt och det finns spår av inklistrade bilder på ytterligare åtta platser i boken. ${ }^{264}$ Flera av dessa små bilder är inklistrade i marginalerna och alla utom en saknar handmålade ramar, till skillnad från de flesta av de större bilderna där ofta ramrester finns kvar. På folio 1v (bild 16) finns tydliga spår av miniatyrramen och på folio 131v är till och med ett pappershörn av bilden kvar, en fortsättning på den röd/vita dekor som omgett bilden. Även på folio 163v finns ett par mycket små rester kvar från bildens ram som visar att det varit en tryckt bild. ${ }^{265}$

De bevarade bilderna i C 12 visar Katarina av Vadstena (f. 117r), Gregoriusmässa (f. 150v) samt en Pietá (f. 152r). ${ }^{266}$ Ett par av de förlorade miniatyrerna har varit helsidesbilder (f. 1v, 131v) medan andra haft betydligt mindre format. Fem bilder, bl.a. Katarinabilden och Gregoriusmässan, har mandelform och är $4 \mathrm{~cm}$ höga och

259 Ett par exempel ses i bönboken C 68 f. 111v, 144v. Ursula Weekes diskuterar en birgittinsk bönbok med isydda bilder från Birgittinklostret Marienwater (London, British Library ms Add. 14042 f. 61v.) i Early engravers and their public 2004 s 167-185. Se enklare exempel i Rudy, Kathryn Postcards on parchment Yale Univ. Press, New Haven 2015 fig. 239.

260 Inga bildförluster i C 475, AM 422, Gießen- eller Rålamb-handskrifterna noterade enligt Hedströms katalog 2009.

261 KB A 1 folio 214v, A 2 folio 106v, A 3 folio 80v (två bilder).

262 Braaten 2006 s 31.

263 Sandgren 2014 s 25.

264 Personliga initialer, c h, för Christina Hansdotter Brask ses på folio 2r, 52r, 142r och 172r. Tunn rosa guldgrund i C 12. Spår av förlorade bilder på folio 1v, 94r, 116r, 121v, 131v, 163v, 186r. Bildprogrammet i C 12 är publicerat i Sandgren "Christina Hansdotter Brask" 2017. Se även https://www.manuscripta.se/ms/100406.

265 Handskriften är tyvärr inte digitaliserad ännu.

266 Sandgren "Christina Hansdotter Brask" 2017 s 157, fig. 5, 7, 8. 
$2,7 \mathrm{~cm}$ breda. ${ }^{267}$ Pietàbilden är däremot femkantig och endast 3,4 cm hög. (Bild 28.) Vilka övriga motiv som troligen prytt bönboken går till stor del att lista ut med hjälp av de bönetexter som står att läsa vid bilderna. (Se bilaga 4.) Den saknade ovala bilden på folio 48r inledde $\mathrm{S}$ Annas tidegärd och har gissningsvis prytts av motivet Anna själv tredje. Förutom S Katarina av Vadstena så har även en oval bild av den heliga Birgitta hört till utsmyckningen (f. 116r), lämpligt placerad strax före dottern Katarina (f. 117r). Jungfru Maria har sannolikt prytt bilden på folio 94r där salutationes börjar: "Jag hälsar dig jungfru Maria..." Med tanke på textens fortsättning är det rimligt att en Bebådelsescen varit aktuell. ${ }^{268}$ Ytterligare en scen med jungfru Maria fanns på folio 163v, i anslutning till Marie sju fröjder. Intill bönen inför Veronikas svetteduk på folio 121v passar en bild av Kristi ansikte naturligtvis bäst, en så kallad Veronikabild. Tyvärr har ingen sådan bevarats från Vadstena kloster, men åtskilliga tryckta och handmålade sådana finns från andra håll. ${ }^{269}$

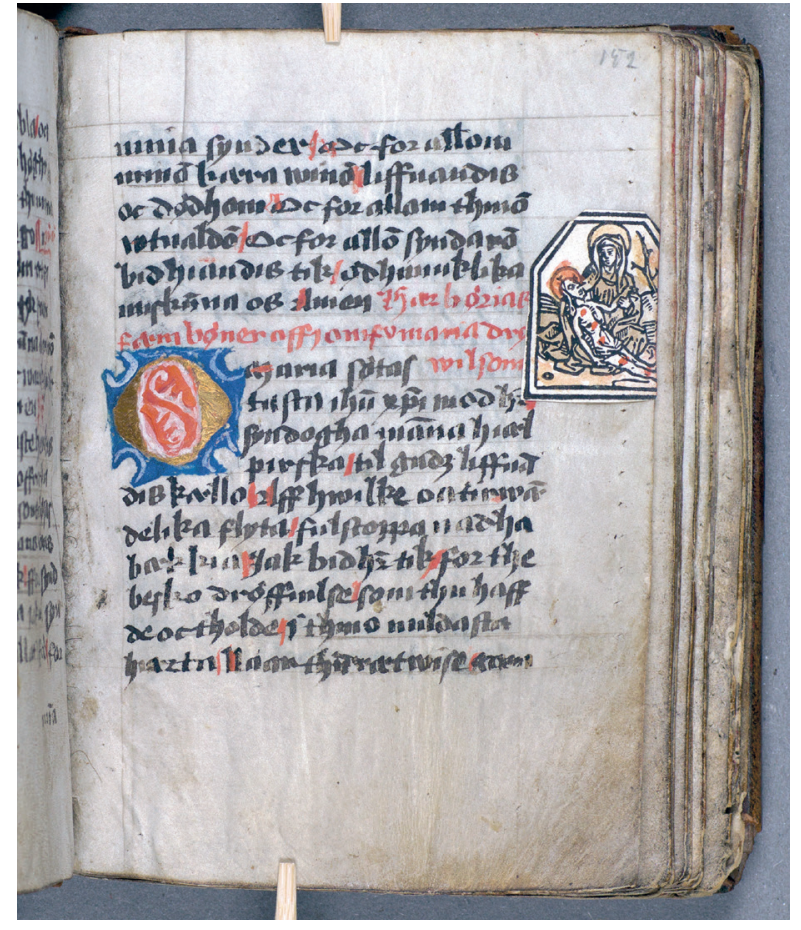

Bild 28. Boksidan fol. 152r i bönboken UUB C 12 visar Pietà $i$ ett kolorerat träsnitt på papper, inlimmat $i$ den yttre marginalen och senare beskuren. Mått ca 11,5 x 15,5 cm. (C) UUB. På folio 132r börjar Birgittas femton böner inför Jesu Kristi lidande (Quindecim orationes), vilken passar att illustrera med antingen en Smärtoman, Arma Christi eller en Kalvariescen på den motstående bildsidan, folio 131v. Bönen som börjar på folio 185v ställs till Jesu heliga namn, varför ett Kristusmonogram passar bäst in på folio 186r, kanske av samma utformning som träsnittet på folio 89v i Ingegerd Ambjörnsdotters nämnda bönbok (A 43). ${ }^{270} \mathrm{Vad}$ som framställts på inledningsbilden på folio $1 \mathrm{v}$ är svårare att svara på. Texten är Helga trefaldighets tidegärd, en vanlig text i bönböckerna. Naturligtvis kan en treenighetsframställning i form av en Nådastol passa bra, som i A 36, ${ }^{271}$ men det finns även andra möjligheter.

Trots att den lilla bönboken C 68 möjligen kan ha tillverkats utanför klostret, finns det goda skäl att betrakta den som en Vadstenahandskrift. ${ }^{272}$ Den har tro-

\footnotetext{
267 Mandelformade bilder var placerade på folio 2r, 48r, 116, 117r, 150v.

268 Se Geete, Robert (red.), Svenska böner frän medeltiden Norstedt, Stockholm, 1907-09 bön nr 123a, s 251-253.

269 Se Hamburger 1997 s 195, 197.

270 Bild se Braaten 2006 s 101 bild 3. Digital fullversion se https://www.manuscripta.se/ $\mathrm{ms} / 100223$.

271 A 36 se https://www.manuscripta.se/ms/100220.

${ }^{272}$ Digital fullversion se https://www.alvin-portal.org/alvin/view.jsf?aq=\%5B\%5B\%7B\%22A FQ\%22\%3A\%22C+68\%22\%7D\%5D\%5D\&c=7\&aqe=\%5B\%5D\&af=\%5B\%5D\&search Type $=$ EXTENDED\&query $=\mathrm{C}+68 \&$ pid $=$ alvin - record\%3A184919\&dswid $=-5614 \#$ alvin record\%3A184919.
} 


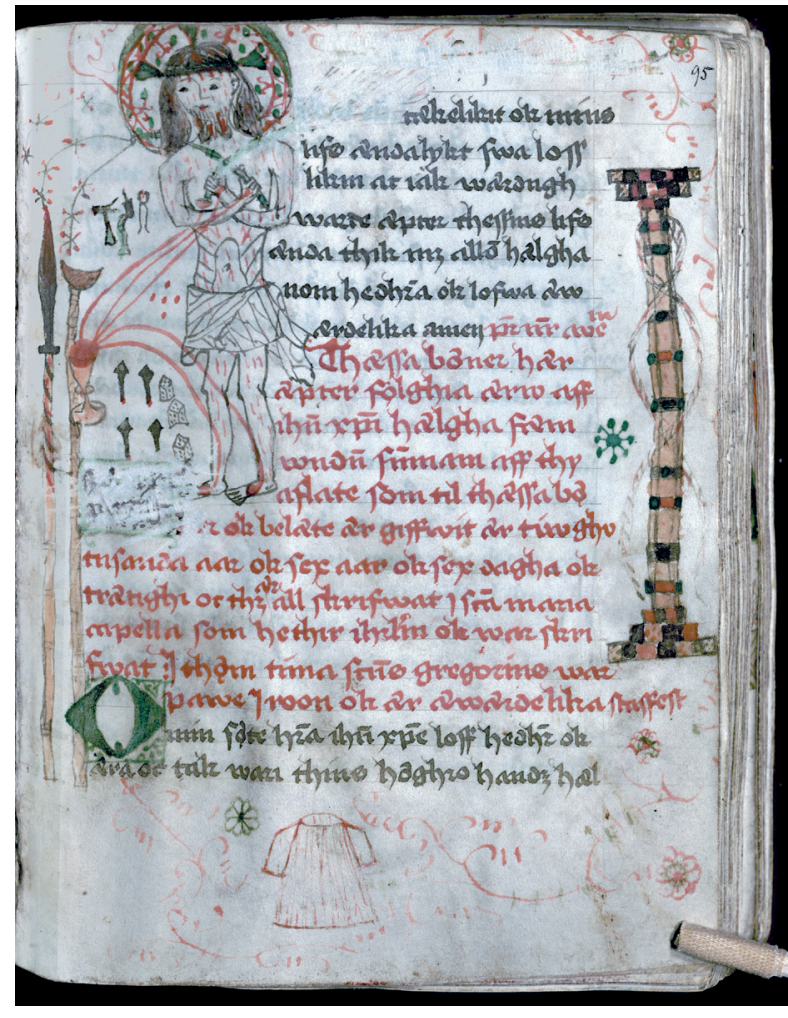

Bild 29. Smärtomannen omgiven av passionsredskapen. Passionsredskapen har placerats ut runt om boksidans text, tillsammans med Kristus framställd som smärtoman. I händerna håller han gisslet och en kalk samlar upp det flödande blodet. Till höger ses pelaren han fästes vid, till vänster Longinus lans, ättiksvampen, de fyra spikarna, hammare, tång samt en raderad skylt. Under texten ses livklädnaden. UUB C 68 fol. 95r. (C) UUB.

ligen införlivats med universitetssamlingen tillsammans med de övriga Vadstenahandskrifterna. Denna bönbok har också förlorat en hel del av sin bildskatt men har kvar några bilder bl.a. i marginalerna. ${ }^{273}$ (Se bilaga 2, 4.) En av de kvarvarande bilderna ansluter i storlek till de små träsnitten i C 12 - folio 97v har ett litet kolorerat träsnitt med en Golgatascen. ${ }^{274}$ De populära kvinnliga helgonen Katarina av Alexandria, Barbara och Dorothea poserar i marginalerna på tre olika boksidor. ${ }^{275} \mathrm{~S}$ Katarina uppträder till och med två gånger, först vid Katarinas tidegärd (f. 47v), och sedan i samband med en bön på folio 127r. I båda bilderna är hon utrustad med sina sedvanliga attribut: hjul, svärd och bok. S Dorothea framställs med sin blomsterkorg (f. 129r). Kvinnorna avbildas i praktfulla röd-gröna dräkter med höga kronor på huvudet och långt lockigt hår. På kinderna ses små röda rosor och de små munnarna har röda läppar. Sättet att teckna ansikten har vissa drag gemensamt med de figurer som ses i Gregoriusmässan i missalet C 420 och Berlinbönboken Theol lat oct $71 .{ }^{276}$ Samma figurteckning ses också i Smärtomannen omgiven av Arma Christi på folio 95r. (Bild 29.) Överhuvudtaget var det nu mycket slitna måleriet i C 68 en gång mycket rikligt, mestadels utfört i rött och grönt. Många av de nedhängande marginaldekorationerna, stjärnor, blommor och lockigt utformade hängen, har nötts bort. Måleriet har en utformning som genom sin sirlighet skiljer sig från merparten av de bevarade illuminationerna från Vadstena. Här finns också spår av ommålning och raderingar i måleriet. ${ }^{277}$ Några blad har skurits bort, samtidigt som texten blivit ifylld för att synas bättre på vissa ställen. ${ }^{278}$

\footnotetext{
273 Sandgren 2014 s 23-26.

274 Bilden $(6,3 \times 5,5 \mathrm{~cm})$ är tryckt på papper och dess baksida är tom.

275 https:/www.alvin-portal.org/alvin/view.jsf?dswid=617\&searchType=TEXT\&query=c+68\&aq= \%5B\%5B\%7B\%22A_FQ\%22\%3A\%22c+68\%22\%7D\%5D\%5D\&aqe=\%5B\%5D\&af=\%5B\%5D \&pid=alvin-record\%3A184919\&c=1\#alvin-record\%3A184919.

276 Bild se https://digital.staatsbibliothek-berlin.de/werkansicht?PPN=PPN859357414\&PHYSID= PHYS_0256\&DMDID=DMDLOG_0033\&view=overview-toc [2020-06-10] eller betaversionen https://digital-beta.staatsbibliothek-berlin.de/werkansicht?PPN=PPN859357414\&PHYSI D=PHYS_0256\&DMDID=DMDLOG_0033 [2020-06-10].

277 Folio 27r ommålad D-initial, raderingar av text och/eller dekor på f. 51v, 105r, 115rv, 127r, $139 \mathrm{v}, 147 \mathrm{v}, 148 \mathrm{r}$.

278 Se Hedström 2009 s 505-506. Ett blad med delar av text bortskuret finns också efter inlagan.
} 
Bilderna i bönboken C 68 tycks ha varit införda med hjälp av tre olika tekniker. De direkt på pergamentet handmålade bilderna är de nämnda jungfruhelgonen, Smärtomannen och ett par röda hjärtan. ${ }^{279}$ Lim har använts för att foga in en handfull bilder, ${ }^{280}$ men det finns också nålhål som tyder på att ett tiotal bilder varit fastsydda. ${ }^{281}$ Några av de insydda bilderna har bara varit fästade längs med ena sidan, i över- eller ytterkanten av boksidorna. Placeringen av nålhålen skulle i dessa fall kunna tolkas som spår efter illuminationsskyddande "gardiner" som i A 12 m.fl., men i C 68 finns bara spår av underliggande illuminationer på två av dessa tio ställen. ${ }^{282}$ Däremot skulle det passa bra in med bilder till texten på dessa ställen, eftersom de är placerade i anslutning till nya textavsnitt eller viktiga böneteman. ${ }^{283}$ (Se bilaga 4.) Placeringen av dem på boksidan visar att några av dem skymt texten, men genom att fästa dem längs ena sidan kunde de vikas undan så att texten blev synlig. Texterna vid de tomma bildytorna tyder på att de förlorade bilderna framställt i tur och ordning: S Anna (50r), ${ }^{284}$ jungfru Maria (61r), ${ }^{285}$ passionsmotiv (89r), Veronika/Sancta facies (99r), ${ }^{286}$ Kristusmonogram (104r), ${ }^{287}$ Uppståndelsen (105r), ${ }^{288}$ Marie smärtor (110r eller v), Marie himmelsfärd (111v, 123v), ${ }^{289}$ evangelisten Johannes (130r) ${ }^{290}$ samt troligen en hostia eller monstrans $(144 \mathrm{v}){ }^{291}$ Ovanför det röda hjärtat på folio $138 \mathrm{v}$ finns ett svärd som utsatts för raderingsförsök. Bönen, Marie fem smärtor, handlar om de fem svärd som genomborrade Marias hjärta inför åsynen av sonens lidande. ${ }^{292}$ Det röda hjärtat med fem svarta sår och fyra spikar, samt svärdet, passar väl ihop med bönen. Stilistiskt närstående till C 68 är Gregoriusmässan i det tidigare nämnda Linköpingsmissalet C 420, en motivframställning som i sin tur har en närstående parallell i Kristina Pedersdotters bönbok, Berlin Theol lat 71 (f. 123v). ${ }^{293}$

279 Röda hjärtan med svarta spikar ses i marginalerna på folio $138 \mathrm{v}, 140 \mathrm{v}$.

${ }^{280}$ Inklistrade bilder troligen på folio 99r, 105r, 111v, 115v(?), 130r, $144 \mathrm{v}$.

281 Hålen har inte med linjeringen av skrivytan att göra. Sömnadsspår i form av antingen hål eller hål med trådrester finns på f. 50, 61, 89, 99, 105, 108, 110, 111, 123 och 144.

282 Spår av lim ses på folio $105 \mathrm{r}$ och $111 \mathrm{v}$.

283 Weekes 2004 s 167-185.

284 Ett blad mellan 49 och 50 saknas och rubriktexten på f. 50r är ofullständig. Bladet kan ha haft en bild av S Anna.

285 Spår efter bild som mäter B: 2,2 cm, H:3,5 cm.

286 Bildytan ca 5,7 cm bred och 6,6 cm hög. Synålshål längs tre kanter.

287 Spåret av bilden består i en ljusare oval fläck i yttre marginalen, ca $4 \mathrm{~cm}$ hög.

288 Många nålhål ses till vänster och höger om och ett par cm under bildytan. Limmet har inte varit utspritt över hela bildytan utan mest i kanterna och mitt på. B: $6,8 \mathrm{~cm}, \mathrm{H}: 10,3 \mathrm{~cm}$ (beskuren vänster). På bildytan finns raderad text där ordet syster nämns två gånger.

289 Folio 111v har många synålshål och en liten röd trådrest kring bildytan, $H: 6,5 \mathrm{~cm}, \mathrm{~B}: \mathrm{ca}$ 4,8 cm (limspår och synålshål stämmer inte i bredd). En skugga som av en bildyta med grönt inslag ses även i marginalen på f. $115 \mathrm{v}$.

290 Det är mycket tydliga limspår efter bildens asymmetriska form, B: 2,5-5,5 cm, H: 11,4 cm.

291 B: $2,5 \mathrm{~cm}, \mathrm{H}: 3 \mathrm{~cm}$.

292 MHUU bd 2 s 51, Hedström 2009 s 513.

293 https://digital.staatsbibliothek-berlin.de/werkansicht?PPN=PPN859357414\&PHYSID= PHYS_0256\&DMDID=DMDLOG_0033\&view=overview-toc. Se även Hedström 2009 s 220 , bild 130 . 

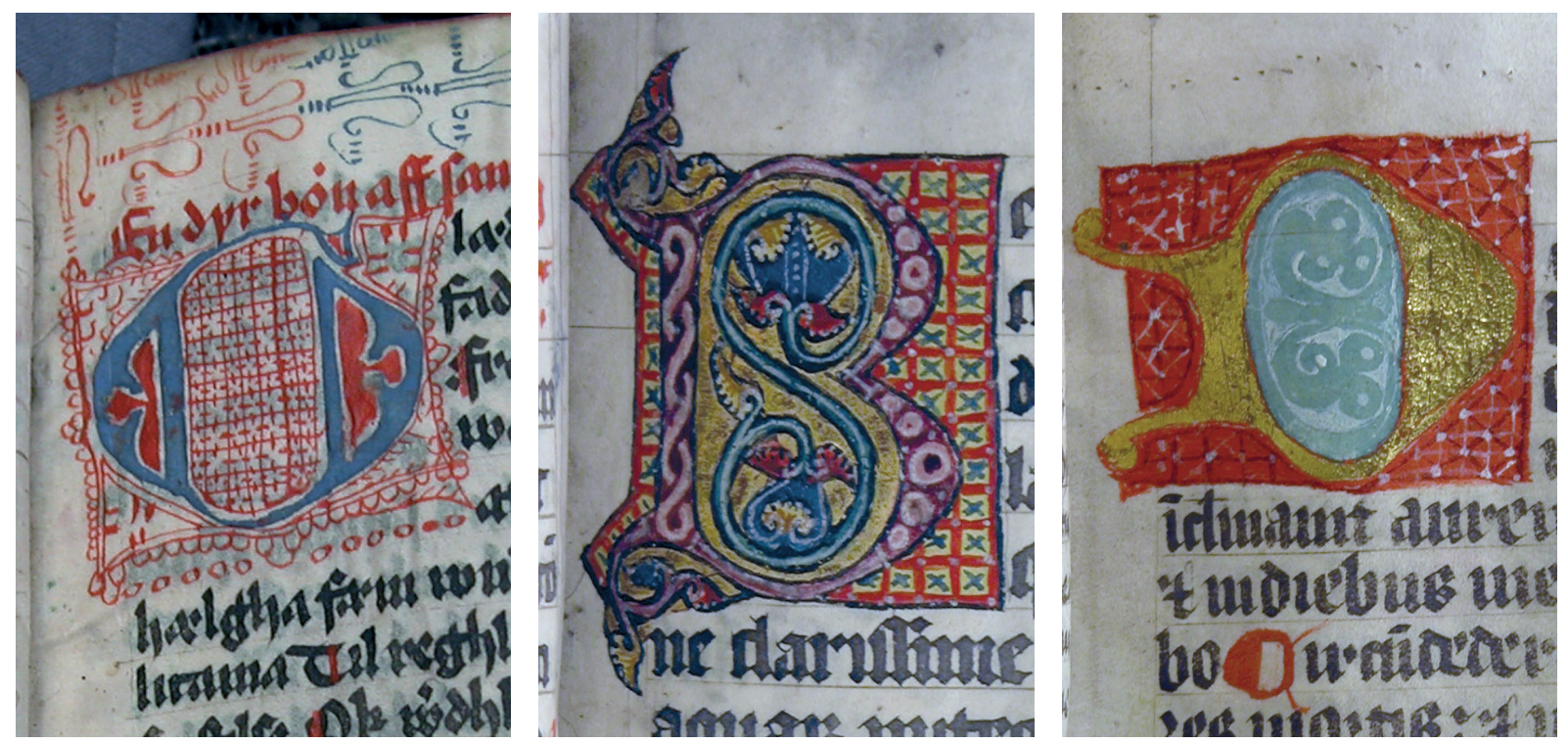

Bild 30. I några av bönböckerna avtecknar sig initialernas bokstavskroppar mot olika varianter av rutiga fonder i exempelvis RA E 9068 f. 29r, UUB C 440f. 64 r och C $475 f$. 75r. Detalj. Foto förf. och UUB.

Bönboken Gießen 881 har eventuellt tillhört Katarina Tyrgilsdotter som inträdde i klostret 1506. ${ }^{294}$ En rikt utsirad filigraninitial med en fågel inuti inleder där de sju botpsalmerna på folio $40 \mathrm{v} .{ }^{295}$ Folio $72 \mathrm{v}$ bär tydliga spår efter en inlimmad helsidesbild som inledning till Trefaldighetstidegärden. På folio 109v finns likaså spår av en förlorad bild som ackompanjerat fyra böner att läsas vid elevationen av hostian. En Gregoriusmässa eller en monstrans/ hostia skulle kunna passa som motiv i sammanhanget. Mellan folio 135v och 136r saknas troligen ytterligare en bild. Den efterföljande texten handlar här om Kristi fem sår och den föregående är bönen "Femton böner till Kristi pina". En framställning av Kristi fem sår, möjligen av liknande slag som i A 43 folio 105r skulle vara passande i sammanhanget. ${ }^{296}$

Margareta Matsdotters bönbok, E 9068, har en utformning som gör den intressant ur flera aspekter. ${ }^{297}$ (Bild 30.) I boken finns även flera lakuner. Initialen $\mathrm{D}$ saknas på folio $2 \mathrm{v}$, folio $31 \mathrm{v}$ har spår av en inklistrad helsidesbild utan ram, på folio 73r saknas en liten miniatyr och dess ram, och på folio $88 \mathrm{r}$ saknas miniatyren, men ramen finns kvar. (Bild 27b.) Hedström finner spår av en ram även mellan blad 125 och $126 .{ }^{298}$ Det försvunna inledande D:et kan ha innehållit en framställning av Treenigheten, då det åter är Helga trefaldighets tidegärd som är aktuell. Vad som kan ha funnits på det bortrivna arket vid folio 31v är svårare att säga då texten före-

\footnotetext{
294 Hedström 2009 s 529-541.

295 Hedström 2009 s 205 bild 120, exempel 6B.

296 Frågan är om suddigheten nederst f. 194v möjligen kan ha samband med en förlorad bild och/ eller om en bild var tänkt att sitta här som komplement till bönerna. Den efterföljande boksidan är felaktigt inbunden och innehåller slutet av Rosenkransbönen från f. 185v-186v.

297 Sandgren 2014 s 16-17.

298 Hedström 2009 s 518.
} 
gås av tre "smärre böner för syndare" och följs av en ofullständig bön som inte identifierats, efterföljd av en nattvardsbön. ${ }^{299}$ På folio $73 \mathrm{r}$ följer femton böner till Kristi pina, rubricerad "sancte Britas böner" av en senare hand. Här är en scen ur passionsberättelsen tänkbar, men ett sådant motiv är också lämpligt för bönetemat på folio 88r. En framställning av Arma Christi eller en Smärtoman är tänkbara alternativ. Hedströms identifierade bildlakun mellan folio 125 och 126 placerar bilden bland helgonbönerna, mitt i Allhelgonabönen (f. 125v-127r). ${ }^{300}$ Något för sammanhanget särskilt passande motiv är svårt att avgränsa, förutom alla helgon.

Gävlebönboken (Vasaskolan ms 2) har haft betydligt mindre utsmyckning än de ovan nämnda bönböckerna, men där har ändå funnits bilder. ${ }^{301}$ På ett par platser har man även skurit bort förhållandevis små initialer som knappast kan ha haft något bildinnehåll. ${ }^{302}$ Lakunen mellan blad 2 och 3 uppvisar rester av en ram. Den är placerad i Trefaldighetstidegärden och skulle kunna ha avbildat Treenigheten $\mathrm{i}$ form av t.ex. en Nådastol. Nära bindningen mellan blad 15 och 16 syns rester från ett tidigare infogat ark. Här handlar bönerna om Tomas tvivlaren respektive Kristi himmelsfärd, följt av Pingstundret. ${ }^{303}$

Även Dorotea Nilsdotters bönbok (A 81) har förlorat bilder. ${ }^{304}$ Kvar finns idag endast den tryckta Markusbild som pryder bakre pärmens insida. Blad 49 har troligen haft en halvsidesbild på rectosidan och en helsidesbild på versosidan. Texten är en Mariabön, vilket tyder på att versosidans helsidesminiatyr framställt jungfru Maria. ${ }^{305}$ Halvsidesbilden på folio 62r bör ha visat Barnamorden i Betlehem eftersom bönen handlar om de oskyldiga barnamartyrerna (som tidigare gick under benämningen "menlösa barn”). På nästa blad, folio 63r, följer bönen till Jesu fem sår, för vilket det finns passande jämförbara framställningar i A 38, A 43 och A 80 som kan ha haft en parallell i den avlägsnade bilden på folio $62 \mathrm{v}$ i denna handskrift.

Eftersom systrarnas tidegärd, Cantus sororum, var en liturgisk nyskapelse fanns inte några självklara bildtraditioner att relatera till för dessa texter och i Vadstena illustrerades de heller inte. Granskningen av de övriga bönböckerna visar däremot att bildprogrammen i dem var av mycket varierande omfattning, men att de inte i något fall följer de internationella konventionerna för tideböcker med Jesu barndomssvit eller passionssvit till Marie tidegärd. ${ }^{306}$ Inte heller finns det spår av de traditionella framställningarna vid Helga korsets och Helge Andes tidegärder eller vid dödsmässan. Genomgången av de sju bönböckerna ovan och tabellen nedan visar även att bildprogrammen i Vadstenasystrarnas bönböcker innehållit sådana motiv som

\footnotetext{
299 Hedström 2009 s 521.

300 Hedström 2009 s 526.

301 Sandgren 2014 s 15.

302 Gävle ms 2 folio 3r, 7r, 13v.

303 Hedström 2009 s 544.

304 Sandgren 2014 s 16.

305 Hedström 2009 s 467.

306 Om dessa bildkonventioner för medeltida tideböcker se exempelvis Sandgren The book of hours of Johannete Ravenelle and the Parisian book illumination around 1400, Acta Universitatis Upsaliensis, Diss. Uppsala, 2002, eller verk av Roger S Wieck 1988 eller abbé Victor Leroquais 1927.
} 
var populära i sin samtid och i den monastiska kontexten. Jungfru Maria och Jesu lidande upptar, givetvis, den största platsen. Därutöver märks helgonbilder, Kristusmonogram och avlatsrelaterade bilder som Sancta facies/Veronica och Gregoriusmässan. Den heliga Birgitta och hennes dotter Katarina förekommer i bilderna, men man kunde möjligen ha väntat sig ett ännu större inslag av bilder med dem, just i denna ordensinterna kontext. De flesta av bönböckerna ovan dateras till perioden efter Katarinas skrinläggning 1489, och fram till ca 1530.

Tabell 1. Tabell över motivförekomst i nunnornas bönböcker.

\begin{tabular}{|c|c|}
\hline Motiv & Antal bilder \\
\hline Anna själv tredje & 4 \\
\hline Apokalyptisk madonna* & 2 \\
\hline Arma Christi* & 1 \\
\hline Bebådelsen & 2 \\
\hline Gregoriusmässa* & 2 \\
\hline Heliga tre konungar & 1 \\
\hline Jesu sår* & 3 \\
\hline Jungfru Maria & 6 \\
\hline Korsbärandet/Passionen* & 2 \\
\hline Korsfästelse & 1 \\
\hline Kristusmonogram & 3 \\
\hline Marie smärtor & 2 \\
\hline Nådastol/Treenighet & 3 \\
\hline Pietà & 2 \\
\hline Sancta Facies/Veronica* & 4 \\
\hline S Barbara & 2 \\
\hline S Birgitta & 5 \\
\hline S Dorotea & 1 \\
\hline S Hieronymus & 1 \\
\hline S Johannes döparen & 1 \\
\hline S Katarina av Vadstena & 1 \\
\hline S Kristoffer & 1 \\
\hline S Maria Magdalena & 1 \\
\hline S Martin & 1 \\
\hline Smärtoman & 1 \\
\hline Helgon (exkl. Birgitta \& Maria) & 14 \\
\hline Mariamotiv & 14 \\
\hline Passionsmotiv totalt & 12 \\
\hline
\end{tabular}

* Motivet är förknippat med avlat.

Treenighetens tidegärd var uppenbarligen en viktig text för nunnorna och står som den inledande tidegärden i nio av de undersökta bönböckerna (C 12, E 9068, A 38, A 81, A 82, Rålamb 4, Gießen 881, Berlin 71 och Gävle 2). I flera fall har bilderna som inlett bönboken och/eller den första tidegärden gått förlorade. Inledningsminiatyrerna har ofta varit i helsidesformat och uppenbarligen haft en viktig plats som 
öppningsbilder i flera bönböcker. ${ }^{307}$ Placeringen innebär också att de i likhet med inledningsbilden i A 80 inte nödvändigtvis haft någon koppling till just den text som följer direkt efter bilden. Istället är det snarast en fristående andaktsbild som möter läsaren som öppnar sin bönbok. Den inledande bilden kunde därför fungera oberoende av texterna och användas som andakts/meditationsbild även utanför nunnekoret. I några fall, som exempelvis A 80, är det en bild som dessutom är förknippad med en viss avlat och ontavvärjande egenskaper. (Bild 15.) . $^{308}$ En antydan om denna lösare relation mellan inledningsbild och inledningstext visar också bildspåren i C 12. (Bild 16.) Där har en inramad helsidesbild på folio 1v flankerat den första textsidan, och den lilla ovala bilden i marginalen intill textens första rader på folio $2 \mathrm{r}$ har troligen haft en närmare koppling till själva tidegärdstexten. Det visar sig således att Vadstenasystrarnas bönböcker som regel hade en inledande andaktsbild, och därefter följde ett varierande antal bilder, placerade i direkt anslutning till de texter som de hörde ihop med. ${ }^{309}$ På så vis kan man säga att nunnorna illustrerade bönerna i sina bönböcker, ofta med helgonbilder. (Se bilaga 2 och 3.)

Man kan givetvis fundera över varför så många av bilderna har försvunnit. Med tanke på att många av dem varit svåra att avlägsna är dåligt lim inte en förklaring. Bilderna kan naturligtvis ha varit attraktiva att tillägna sig för eget bruk i den mån som de varit gångbara efter reformationen. De kan å andra sidan också ha betraktats som allt för katolska i framtoningen och därför refuserats, trots att bönerna är lika katolska som motiven. (Texten kanske var svårare att uttyda än motiven.) De sekundära anteckningar som återfinns i marginaler, och ibland på de tomma bildytorna i A 80, vittnar om en klart antikatolsk referensram hos en läsare från senare tid. ${ }^{310}$

\section{Bildmiljön på nunneläktaren}

\section{Nunneläktaren och bönboksbilderna}

Avsnittet ovan behandlade själva handskrifterna och deras utformning. I det följande ska istället deras användning i kyrkan stå i fokus. När systrarna gick till kyrkan får man föreställa sig att de gick två och två i en lång rad, i en procession som startade i dormitoriet eller vid kapitelsalen, beroende på vilken tid på dagen det var. Strax innan de klev in i kyrkan, passerade de den öppna grav som heliga Birgitta föreskrivit

307 Första tidegärden är Treenighetens i A 36, A 38, A 81, A 82, Berlin, C 12, C 68(?), E 9068, Gießen, Gävle, C 471. (Första tidegärden är Helige Andes i A 43, A 80, C 475, C 443, C 475, C 502.)

308 Sandgren 2014.

309 Se Sandgren 2014.

310 Kommentarerna är skrivna under 1700-1800-talen och använder omdömen som "münkedikter" (f. 98r), "ynklig münkedikt" (f. 120v), "usel münkedikt" (f. 136v),"tarvlig vantro" (f. 145r), "hvilken vantro och enfaldighet" (f. 152r), "üsel påfvedikt" (f. 170v), "fjållighet" (f. 181v), "üselt påfve- och münkedikt" (f. 195v). 
att de dagligen skulle passera och stanna upp vid i samband med tersen. ${ }^{311}$ Därefter gick de in i kyrkan via en gångbro, förankrad i den nordöstra delen av läktaren. På väg till sina respektive platser passerade de och hälsade Kristus (monstransen) och bilden av jungfru Maria på deras andaktsaltare. De femton passionstavlor som var placerade på läktarens västra vägg gick de till vid fredagens Botpsalmsprocession. ${ }^{312}$ Väl på sina platser hälsade de med en bugning Mariaaltaret i öster, och vid vespern även varandra, innan de satte sig i korstolarna. När de sjöng tidebönerna hade de helst sina böcker framför sig i knäet för att läsa och sjunga rätt. ${ }^{313}$ I de Vadstenahandskrifter som innehåller Cantus sororum finns som sagt inga spår av bildprogram, till skillnad från de ovan diskuterade bönböckerna. ${ }^{314}$ De tycks så att säga ha lämnats figurfria, men däremot finns det dekorerade anfanger i dem som både underlättade att hitta i dem under läsningen och betonade vissa partier. Frågan är om det möjligen kan vara en medveten tolkning i linje med grundarinnans restriktioner, att hålla en dämpad karaktär och inte förvilla de fromma tankarna med figurativa framställningar. Samtidigt är bokmåleriet i dem dekorationer, dvs. stick i stäv med vad som gällde för kyrkorummets utsmyckning. Som framgått tidigare tillät man dessutom ägandet av påkostade bönböcker och psalterier. ${ }^{315}$ Andaktsböckerna fanns till hands i nunnornas korstolar, och i koret fanns fler liturgiska böcker att låna för den som behövde. ${ }^{316}$

Förutom en stor mängd kortare böner innehåller den ovan flera gånger nämnda bönboken C 12 två tidegärder (Treenighetens, Helige Andes) samt dödsmässan (requiem) och Botpsalmerna. Botpsalmerna var alltså en del av veckoritualen, men eftersom de inte ingick i Cantus sororum finns de inte med i de handskrifterna. Däremot hörde Botpsalmerna till standardtexterna i dåtidens tideböcker. Som genomgången av bildprogrammen visade möttes den nunna som öppnade $\mathrm{C} 12$ en uppsättning bilder som dels visade på Katarinas, Birgittas och jungfru Marias föredömliga exempel på Kristi efterföljelse, dels hade målet att underlätta hennes jordiska salighetsväg till himmelriket eller via avlatsförknippade fromhetsövningar lindra den förväntade plågan i skärselden. (Se bilaga 2 Bildprogram.) I bönboken skapar text och bild en tätt sammanvävd spiritualitetstematisk helhet, präglad av skildringen i Birgittas Uppenbarelser och det synsätt som förmedlas i dem utifrån jungfru Marias perspektiv på frälsningsverket.

Bönboken $\mathrm{C} 12$ innehåller även kortare meditationer för sju olika stationer under de likaledes sju Botpsalmerna, utformade i nära anslutning till texten i Birgittas

311 Regula Salvatoris kap. 27. Lundén bd IV 1959 s 35.

312 SDHK 33406.

313 "Oc hwar een syster haffui siin psaltara ypnan fore sik, at ey warde maärkelikin willa ällir oliwdh j chorenom" Klemming 1883-84 s 65-66.

314 UUB C 440 är enligt min uppfattning troligen inte gjord i Vadstena utan i Munkaliv i Norge.

315 Andersson, Elin, Responsiones Vadstenenses: perspectives on the Birgittine rule in two texts from Vadstena and Syon Abbey: a critical edition with translation and Introduction, Acta Universitatis Stockholmiensis, Diss. Stockholm, 2011 s 163.

316 Enligt kommentar i C 473 fol 1r, se MHUU bd 51992 s 190. 
Uppenbarelser. ${ }^{317}$ Psalmerna lästes under det att man gick i procession i klosteromgången, och avslutades med läsning av litanian i respektive systra/brödrakor. ${ }^{318} \mathrm{Ex}^{-}$ akt hur denna fredagsprocession med stationsmeditationer gick till i detalj, vet vi inte. Den skulle enligt Lucidarium utföras med värdighet, gå utmed korsgången, avslutas i nunnekoret och ledas av en syster bärande en Mariabild. ${ }^{319}$ Sannolikt följde man allmän klosterpraxis och startade processionen i kapitelsalen. Psalmerna lästes medan man vandrade. Om nunnorna verkligen gick runt korsgångens alla fyra längor två och två, blev det väldigt trångt när de passerade mellan det nu försvunna kapitelhuset och kyrkan. Det är därför tänkbart att processionen inte gick hela varvet runt, utan att man nöjde sig med de andra tre bredare korsgångslängorna, dvs. gick medurs från kapitelhuset, innan man skred uppför trappan till nunnekoret. Om bönbokens sju stationer skall användas under processionen innebär det att nunnorna stannade upp vid särskilda platser i korsgången, sannolikt försedda med ackompanjerande lämpliga motiv. Enligt det tidigare nämnda avlatsbrevet från 1496 hörde den nionde av de femton birgittinska passionsstationerna, Kristus dignar under korset, till den senare delen av denna processionsritual. ${ }^{320}$ Passionstavlorna var placerade på västra delen av nunneläktaren. Det innebär att systrarna passerade tvärs över hela nunneläktaren, knäfallande bad de därpå litanian, vända mot triumfkrucifixet och högkoret i väster, och sedan intog de sina platser.

Omfattningen på utsmyckningen i bönboken C 12 utgör en mellannivå i Vadstenamaterialet med sina tretton eller fjorton figurativa framställningar. (Bilaga 2, 4.) Flera av bönböckerna har som vi sett bara haft ett fåtal bilder, som exempelvis A 36, A 38, A 81, E 9068 och C 443. Bönböckerna A 43 och A 80 har däremot haft mer omfattande bildprogram, nio respektive nitton bilder. När Ingegerd Ambjörnsdotter (A 43) och Birgitta Andersdotter (A 80) intog sina korstolar hade de troligen inte bara sina Cantus sororum-handskrifter till hands, utan också dessa rikt illuminerade bönböcker. I dem fanns böner för allehanda tillfällen, både inom och utom koret. Det var böner som kompletterade både det dagliga bönelivet och det liturgiska året, genom exempelvis böner för avlidna systrar och bröder på deras minnesdagar. Där fanns också bilder och böner kopplade till vissa specifika andaktsövningar, till avlater och till enskilda helgon. ${ }^{321}$ Ingegerd Ambjörnsdotters bönbok inleds av jungfru Maria med Jesusbarnet (f. 4v), ett motiv som fanns i syster Ingegerds närhet där

317 Björkman, Ulf, Stilla veckan i gudstjänst och fromhetsliv, med särskild hänsyn till svensk medeltida tradition, Gleerups, Lund, 1957 s 112, 124, nämner även UUB C 50, KB A 49 och biskop Tidemansons avlatsbrev från 1470 med överensstämmande stationsandakter. Samma text som i UUB C 12 återfinns även i UUB C 502.

318 Revelationes Extra. kap 9 nämner dock inte hur dags på dagen. Lundén bd VI 1959 s 120.

319 Bilden i processionen nämns ej i Regula Salvatoris, men i Lucidarium enl. Klemming 1883-84 s 102.

320 SDHK 33406. De femton stationerna är: 1. fottvagningen, 2. nattvardens instiftande, 3. bönekampen på Oljeberget, 4. Judas förräderi, 5. rannsakningen inför överheten, 6. hudflängningen, 7. törnekröningen, 8. korsdragandet, 9. dignandet under korset, 10. Golgata, 11. korsnedtagningen, 12. moderns sorg över sonen, 13. begravningen, 14. mötet med modern vid graven, 15. himmelsfärden.

321 Ibland har helgonurvalet i bönböckerna sannolikt en koppling till namnet på den som ursprungligen ägt boken, men inte i dessa två bönböcker. 


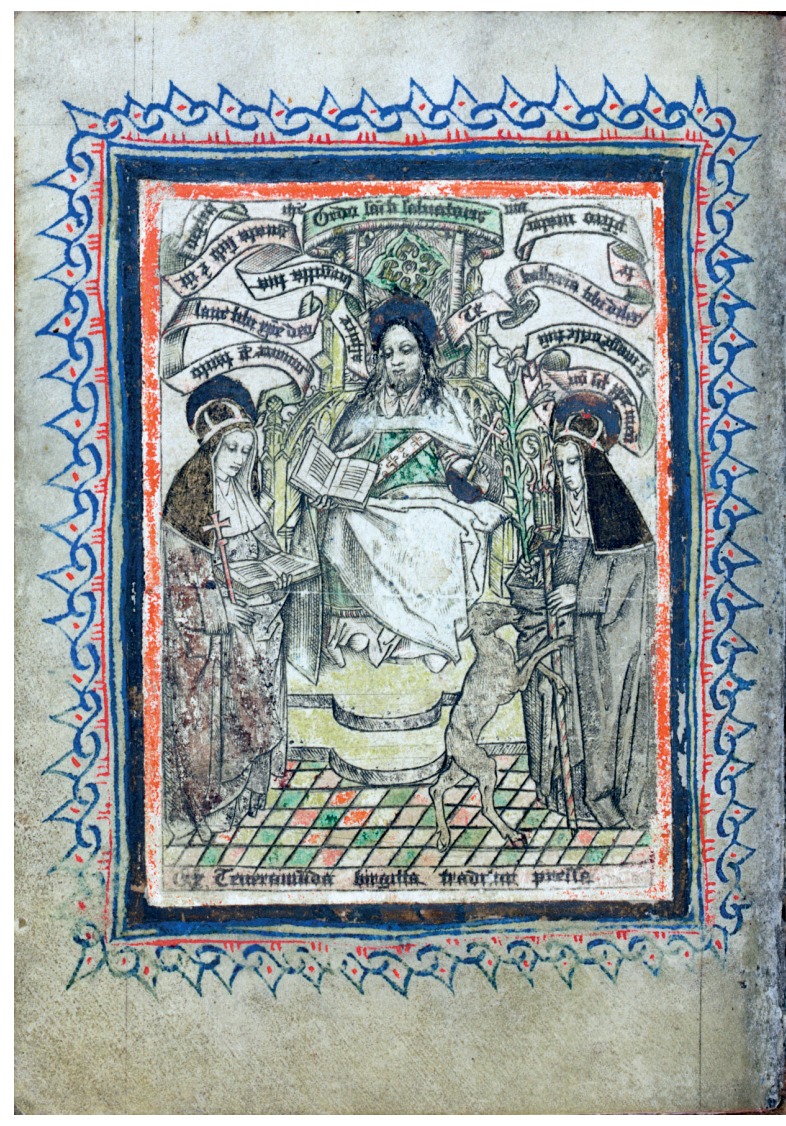

Bild 31. Heliga Birgitta och hennes dotter, saliga Katarina, samtalar med Kristus. Kolorerat träsnitt på papper med handmålad ram på pergament. Träsnittet bär en inskription att det är från Dendermonde (bär: Teneramonde). Bilden är inklistrad i Ingegerd Ambjörnsdotters bönbok, Kungliga biblioteket A 43 f. 43v. (Förminskad och beskuren.) Mått 11,5 $\times 16 \mathrm{~cm}$. Foto Jens Gustavson, KB. hon satt i sin korstol, nämligen på Mariaaltaret, en våning upp vid den östra väggen. Bilden av heliga Birgitta och Katarina i samtal med Kristus (f. 43v) ramar tematiskt in bönbokens ägarinna som birgittinsk. (Bild 31.) Gregoriusmässan hör till de populära avlatsrelaterade motiven i bönboken (f. 119r). Framställningen av Anna själv tredje (f. 123v) hör inte bara hemma i den dåtida folkliga fromheten utan var också ett kontextuellt viktigt motiv i den marianskt präglade birgittinska kontexten - utan sankta Anna ingen jungfru Maria. I klosterkyrkan fanns dessutom minst tre olika Annaaltaren varav ett tillhörde klostret. Av de två manliga helgon som sannolikt framställdes i syster Ingegerds bönbok hörde den ene, S Johannes döparen, även till den rumsliga kontexten och den andra, S Kristoffer, till den samtida fromheten. Det är dock tveksamt om nunnorna ens kunde skymta Johannes döparens altare på norra sidoläktaren när de i processionerna tågade in eller ut från nunneläktaren. Ett par av bilderna i Ingegerd Ambjörnsdotters bönbok har en mer emblematisk komposition och kunde fungera både som meditationsbild och som textledsagare. Det är många senmedeltida bönbokstexter som kan läsas med Kristi passionsredskap och hans sår i fokus. Den mest konkret birgittinska av alla bilderna i bönboken är emellertid miniatyren med Agnus Dei och passionsredskapen (f. 160r). Den är nämligen försedd med namnen Jesus, Maria och Birgitta. (Bild 32.) För syster Ingegerd stod heliga Birgitta som vägvisare till jungfru Maria, vilken i sin tur var Ingegerds förebild i Kristusefterföljelsen som nunna. Bönbokens bilder och texter pekar på och befäster detta val av livsväg.

När Birgitta Andersdotter (1481/85-1532) slog upp sin bönbok (A 80) föll ögonen på bilden av det i naturlig storlek återgivna Kristi sidosår och några av passionsredskapen (f. 15v, bild 15). Den fungerade som andaktsbild och inledning till hela bönboken, men lite längre fram i boken kunde hon också läsa den text som brukade höra ihop med den här typen av passionsbilder med verklighetsanspråk (f. 168v-169r). ${ }^{322}$ Kristi passion och frälsningsgärning har framställts i ytterligare några av bönboksbilderna, liksom jungfru Maria. I korstolen på nunneläktaren befann sig syster Birgitta mellan dessa två visuellt betonade teman: Mariaaltaret i öst och de femton

322 Sandgren, Eva Lq, "Bilden av Kristi sidosår i Birgitta Andersdotters bönbok", Memento Mori: døden i middelalderens billedverden, Nordiska symposiet för ikonografiska studier, red. K. Bliksrud, L. Liepe, Novus, Oslo 2011 s 127-128. 
passionsbilderna på läktarens västverk. Till de avlatsrelaterade bilderna hör, förutom den inledande bilden av Kristi sidosår, även Gregoriusmässan (f. 183v), Veronikas svetteduk (f. 191v) och den Apokalyptiska madonnan (f. 193v). Således motiv som var förbundna med vissa andaktsövningar/ böner. Bönboken har även haft sex helgonbilder, men det finns inget som tyder på att heliga Birgitta eller dottern Katarina avbildats. A 80 är den till antalet bilder mest påkostade bönboken från Vadstena med sina ursprungligen nitton miniatyrer, men bara den inledande bilden har bevarats. Boken är också ett exempel på att systrarna kunde ärva bönböcker av varandra. Som nämnts ovan finns dels ett antal böneingresser där initialerna som syftar på Birgitta Andersdotter har raderats mer eller mindre väl, dels ser man överst på folio 16r att de nuvarande initialerna KB har målats ovanpå de raderade initialerna BA. (Bild 15.) En så påkostad bok som syster Birgittas passade väl för den senare abbedissan Katarina Bengtsdotter (Gylta, 1546-93).

Förmodligen är både Ingegerd Ambjörnsdotters och Birgitta Andersdotters bönböcker mer påkostade än vad som var normalt för systrarnas bönböcker. Som framgått har de flesta istället spår

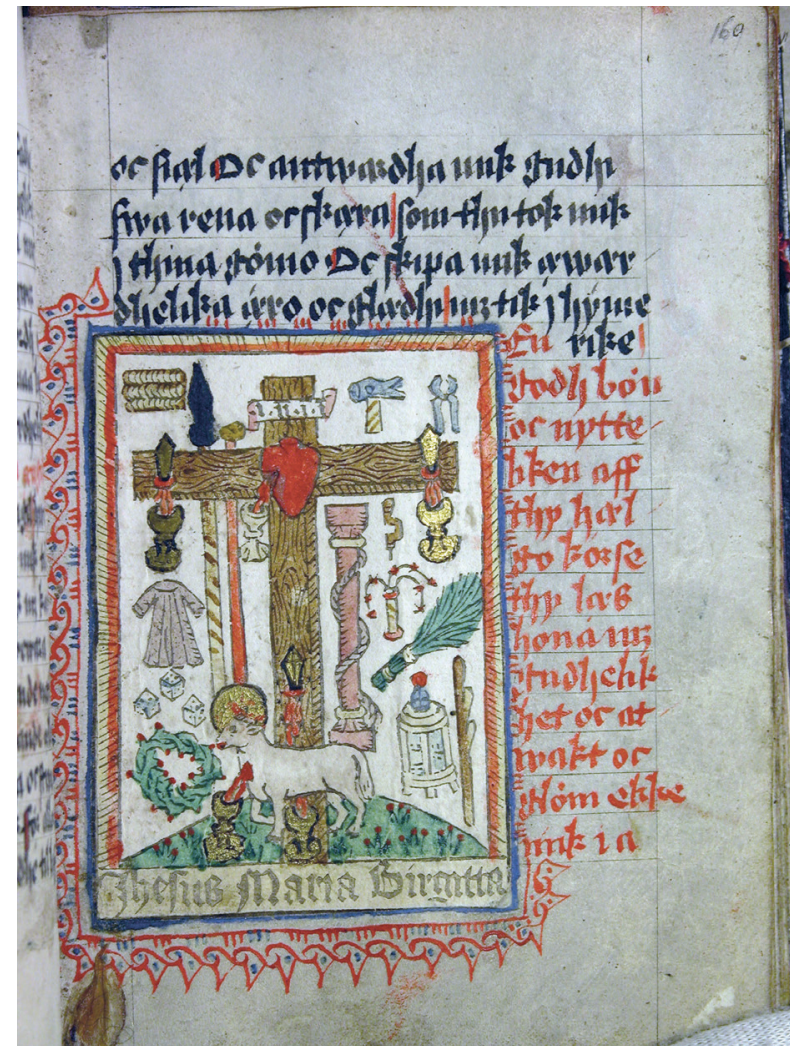

Bild 32. Bilden med Agnus Dei och Arma Christi, (Kristi pinoredskap) pryds undertill av namnen Jesus, Maria, Birgitta. Kolorerat träsnitt i KB A 43 f. 169r. Mått 11,5 × $16 \mathrm{~cm}$. (Beskuren.) Foto Jens Gustarsson, KB. av en knapp handfull bilder. ${ }^{323}$ (Se bilaga 2.) Tillsammans med de bildlösa Cantus sororum innebär det en låg profil jämfört med bildförekomsten i många senmedeltida nunnekloster internationellt sett. Det var alltså inte någon bildmättad bok som systrarna höll i sina händer under fredagsprocessionen eller de många stunderna i koret. Och även om det finns boksidor med enbart dekorativa marginalrankor utan figurframställning, förekommer få saker som kan avleda uppmärksamheten från liturgins eller andaktens innehåll. På så vis borde de ha tilltalat heliga Birgittas återhållsamhet. Det innehåll som betonades i bild och text i dem låg i linje med både den marianskt vinklade passionsspiritualitet som föreskrevs av Birgitta och den fysiskt konkreta fromhetspraxis som utformades under senmedeltiden. Den tog sig uttryck i detaljrika innerliga böner, visuella skildringar av Kristi pinade lemmar och lovsjungande av jungfru Marias ljuvliga kroppsdelar. Från sina korstolar på läktaren hade nunnorna triumfkrucifixet och tavlorna med Kristi passionsvandring i väster, och föredömet Maria i öster. Oavsett om de riktade blicken åt öster eller väster blev de påminda om Kristi frälsningsgärning och Marias roll i frälsningshistorien. En

323 Antal spår av eller bevarade miniatyrer är tre stycken i Gießen 881, C 443, E 9068, A 12, A 81. Två bilder i Berlin 71, Gävle 2, A 38, A 36, och en i Rålamb 4. 
skulpterad Mariabild hängde därtill centralt i kyrkans tak sedan 1466, troligen upphängd på samma sätt som över nunneläktaren i klosterkyrkan i Lüne. ${ }^{324}$ På kyrkgolvet, i utrymmet mellan pelarna som bar upp jungfru Marias kor och nunneläktaren, reste sig dessutom Birgittaaltaret med dess magnifika altarskåp. ${ }^{325}$ Förmodligen stod heliga Birgittas silverskrin uppe på Marialäktaren, väl synligt, och för nunnorna var det placerat som en förgrund till det upphöjda Mariaaltaret. För nunnorna innebar det att både heliga Birgitta och jungfru Maria var samlade i blickfånget mot öster. Men det handlade inte bara om påminnelse utan också en textuell och visuell styrning av det andliga livet i rätt riktning. På Vadstenanunnornas andaktsaltare var ju Kristus dessutom fysiskt närvarande genom hostian i monstransen.

\section{Altare och andaktsbilder på nunneläktaren}

Hur nunneläktaren var inredd finns det tyvärr inga vittnesbörd om. Birgittas instruktioner är som sagt vaga både när det gäller storleken, den exakta placeringen i rummet och inredningens utformning. Det som föreskrivs är att det skall finnas ett andaktsaltare med en monstrans ständigt uppställd. ${ }^{326}$ I monstransen visades givetvis en invigd hostia, genom vilken Kristus således var närvarande. Vid processioner kunde också en Mariabild bäras med och ställas på altaret. För gudstjänsternas textläsningar måste det ha funnits en läspulpet. De sextio korstolarna måste ha varit uppställda mittemot varandra, troligen i dubbla rader, på norra respektive södra sidan av läktaren. Detta bekräftas av att vespern inleddes med att man bugande hälsade varandra på de båda sidorna, vilket nämndes tidigare. ${ }^{327}$ Abbedissa och priorinna skulle sitta längst fram på var sin sida, dvs. närmast öster. De nyaste medlemmarna satt längst bort i raden, mot väster, och gick sist i processionerna. ${ }^{328}$ Att det fanns en korsväg på läktaren framgår av avlatsbrevet från Linköpingsbiskopen, som likaledes nämnts förut.

I många rekonstruktionsmodeller och t.ex. det nederländska träsnittet (bild 11), ansluter nunnornas gångbro till en placering mitt på läktarens norra sida. Som berördes i kapitel 1 var detta troligen inte fallet i Vadstena. Gångbron från dörröppningen i nordväggen ledde istället till nunneläktarens främre/östra del, så att de många in- och uttågen fungerade smidigt. Från kyrkan ledde dörren ut till den korridor på andra våningen som gick till dormitoriet i norra konventslängan. Det blev då smidigt att ta sig mellan dormitoriet och kyrkan vid dagens första och sista tideböner. En aspekt av placeringen av läktaren som heliga Birgitta nämner, är att det

324 SDHK 28 576. Bön inför den hängande Mariabilden i Vadstena gav 40 dagars avlat. Exempel i Kloster Lüne se https://www.kloster-luene.de/klosteranlage/geschichte [20200904].

325 Bild se t.ex. https://sketchfab.com/3d-models/st-birgitta-altarpiece-vadstena-abbey-church49176b466b6342b1ba190c83c665f928.

${ }^{326}$ Revelationes Extra. kap. 37. Lundén bd IV 1959 s 140-141.

327 Regula Salvatoris kap. 5. Lundén bd IV 1959 s 18.

${ }^{328}$ Regula Salvatoris kap. 18 \& 26. Lundén bd IV 1959 s 28, 35. Leksystrarna deltog ej i korsystrarnas böner. 
ska gå att se såväl högaltare som Mariaaltare från nunneläktaren. ${ }^{329}$ Det skall alltså finnas en öst-västlig siktlinje. Samtidigt var det mycket viktigt att nunnorna inte kunde ses. Någon form av avgränsning måste ha funnits både längs med gångbron och runt läktarens sidor. En viss avgränsning gav möjligen de bakre korstolarnas ryggar, men det bör ha funnits någon ytterligare avskärmning, en läktarbröstning av något slag. Behovet av siktlinje mot öster och väster gör att det antingen inte kan ha varit så höga solida avgränsningar på kortsidorna att nunnorna överhuvudtaget inte kunde se ut och ned mot högkoret i väster, eller så var det någon form av genomsiktliga galler, utformade så att det gick att ana på håll vad som fanns utanför läktaren. Det är också möjligt att åtminstone avgränsningarna mot väster var konstruerade så att de kunde öppnas när så önskades. Sådana öppningsbara avskärmningar har man haft i exempelvis det tyska birgittinklostret Altomünster. ${ }^{330}$ Avskärmningen mot Mariaaltaret i öster kan dessutom ha varit annorlunda utformad än mot väster eftersom det inte fanns samma möjlighet till insyn från lekfolk från öster, och i likhet med nunneläktaren var Mariakoret placerat en våning upp från kyrkgolvet.

I samband med Botpsalmsprocessionen diskuterades Linköpingsbiskopens avlatsbrev från $1496 .{ }^{331}$ Det framgår inte bara att det fanns femton målade passionsbilder uppsatta på västra sidan, dvs. insidan av nunneläktaren. ${ }^{332}$ Brevet berättar också att bilderna satt längst bak i nunnekoret, dvs. väster. Motivet som gav den utlovade avlaten utgjorde den nionde scenen i den femton scener långa birgittinska korsvägsandakten, vilken skiljer sig något från andra gängse senmedeltida stationsvandringar, som ofta har fjorton scener. ${ }^{333}$ Bildprogrammet är skapat som en vandring tillsammans med jungfru Maria, i enlighet med skildringen i Birgittas Uppenbarelser. ${ }^{334}$ Brevet avslöjar indirekt att nunnorna alltså kunde företa en komplett passionsvandring uppe på läktaren på samma sätt som bröderna i sin klostergård, och lekfolket runt kyrkogårdsmurens stationer. ${ }^{335}$ Att göra så var inte bara en from övning under passionstiden. Det var också ett sätt att utföra en pilgrimsfärd i anden, istället för på fysisk plats i Jerusalem, och var en populär och viktig andaktsform bland nunnor under senmedeltiden och förknippad med avlat. ${ }^{336}$ För birgittinerna var det dessutom en vandring i jungfru Marias och heliga Birgittas fotspår, som i Uppenbarelserna.

Det är möjligt att miljön på läktaren i praktiken var mer bildrik än vad heliga Birgitta hade tänkt sig. Både läktaravskärmningar och korstolar var lämpliga

\footnotetext{
329 Regula Salvatoris kap. 12. Lundén bd IV 1959 s 25.

330 Enligt muntlig uppgift från fil dr Volker Schier 20 januari 2017.

331 SDHK 33406.

332 Härdelin 2003 s 29.

333 Se ex.vis. "korsväg” Nationalencyklopedin. http://www.ne.se/uppslagsverk/encyklopedi/lång/ korsväg.

${ }^{334}$ Härdelin 2003 s 19, 25. Härdelin refererar till UUB C 50 f. 151r, där stationerna förtecknas. Se även Björkman, Ulf Stilla veckan i gudstjänst och fromhetsliv, Gleerups, Lund 1957 s 124-125.

335 Sigurdsson \& Zachrisson 2003 s 141, 145.

336 Se exempelvis Rudy, Kathryn, Virtual pilgrimages in the convent, Imagining Jerusalem in the late Middle Ages. Brepols, Turnhout, 2011.
} 


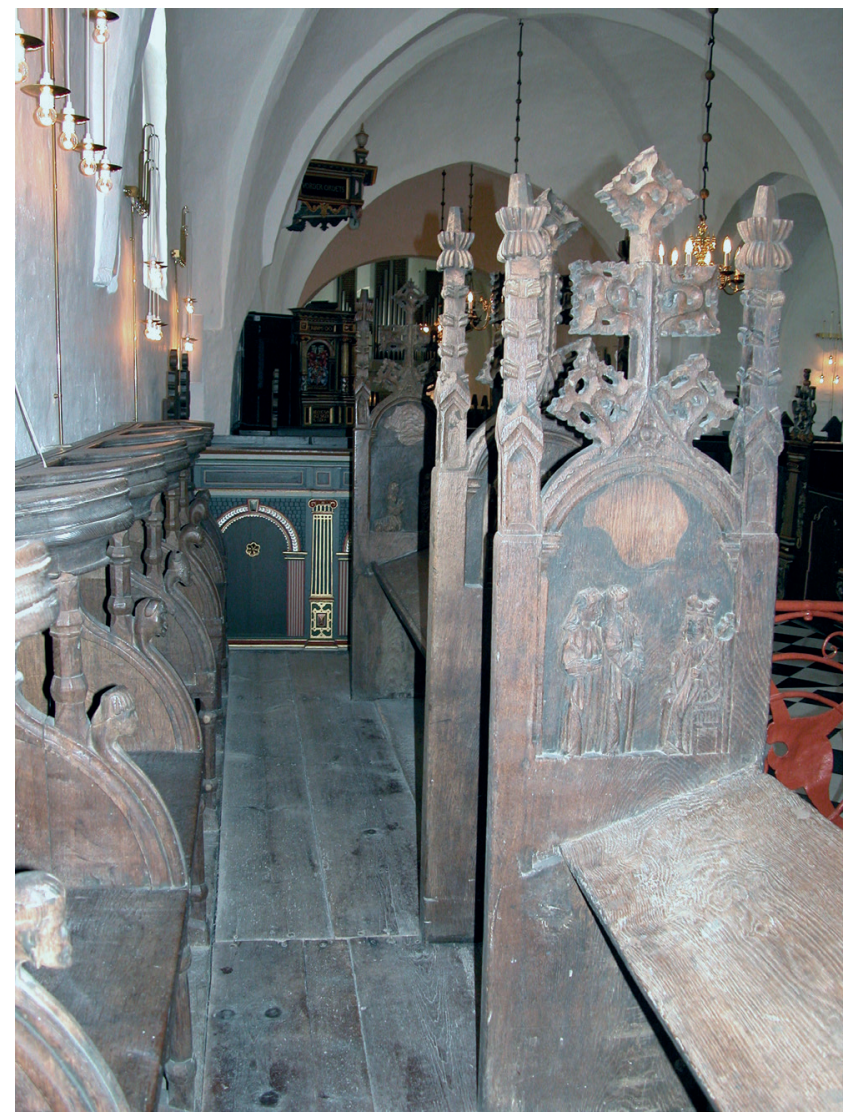

Bild 33. Några av de snidade och bildförsedda korstolarna frän Mariagers klosters nunneläktare har bevarats. De finns numera $i$ den närbelägna kyrkan i Visborg, Jylland. Foto förf.

platser för bildmässig utsmyckning. Nunnornas korstolar finns tyvärr inte kvar. En indikation på hur de kan ha varit utformade ger de senmedeltida korstolarna från Mariagers birgittinkloster i Jylland. De har snidade så kallade miserikordier på undersidan av sittklaffarna och mer fromma motiv på gavelstyckena, samt spår av vapensköldar. ${ }^{337}$ (Bild 33). Även i klosterkyrkan i Maribo fanns de snidade korstolarna kvar långt efter reformationen, men är nu borta. ${ }^{338}$ De två par korstolar som har bevarats i Vadstena klosterkyrka härrör eventuellt från munkkoret. De kan identifieras i 1600-talsplanerna, placerade i det nya lutherska högkoret vid Birgittaaltaret. Stolarna finns med även på planen från 1700-talets början, men att döma av J. F. Martins hundra år yngre bild har de sedan ställts undan i den gamla sakristian. (Bild 9.) 339 Även om de hört hemma i brödernas kor kan de ge en fingervisning om hur systrarnas korstolar utformades. Korstolarna har en mycket enkel och diskret snidad dekor i form av små sexuddiga rosor, dvs. samma slags rosor som förekommer i broderierna. Att döma av de spikhål som finns på ryggstyckenas insidor och gavlarnas utsidor är det dock troligt att de även prytts av fastspikade bilder, kanske

\footnotetext{
337 De bevarade åtta korstolarna finns sedan lång tid tillbaka i den närbelägna Visborgs kyrka.

338 Korstolarna i Maribo såldes 1793 enligt Norn 1948 s 68.

339 Tre korstolar är utritade i UUB Palmskiöld 294, men det är två dubbla korstolar som har bevarats. Korstolar syns i J F Martins bild.
} 
av textil. Att fästa textilier på korstolarnas insidor skulle inte bara ha gett ögonfröjd utan även bidragit till ett behagligare klimat, vilket kunde vara önskvärt med tanke på antalet timmar man varje dag tillbringade i dessa korstolar.

Med hjälp av de över två meter höga ryggarna på korstolarna skulle det alltså vara möjligt att skapa en rumslig avgränsning mot söder och norr. I kombination med den upphöjda placeringen på läktaren behövdes det eventuellt inte ytterligare höga läktarbröstningar på nunneläktaren för att avskärma från lekfolkets insyn. Av den västra läktarbröstningens övre del krävdes att nunnorna skulle kunna se över/ igenom den mot högaltaret, dessutom fordrades tillräckligt med plats för de femton passionsbilderna. Om bilderna var placerade utmed hela västra sidan innebär det att de upptog 20 alnars längd, eftersom varje travé skulle vara 20 alnar i kvadrat, dvs. knappt 11 meter. Det innebär att i praktiken hade varje stationsbild högst $70 \mathrm{~cm}$ till sitt förfogande på bredden, om de placerades tätt. Eftersom avlatsbrevet säger att bilderna var målade kan de fragment av lerreliefer, med i och för sig passande motiv, som påträffades vid utgrävningarna i början på 1960-talet, avskrivas från detta sammanhang. ${ }^{340}$ Det är mer troligt att de mer väderbeständiga relieferna funnits i utomhusmiljön, möjligen i brödernas korsgång eller lekfolkets stationsvandring kring bogårdsmuren. ${ }^{341}$ Nunnornas passionssvit fick kanske följa med dem när de tvingades flytta sina tideböner från läktaren till det övergivna brödrakoret omkring 1550 .

Avlatsbrevet från 1496 är det enda dokument som uttryckligen nämner något om bildmiljön på läktaren, men eftersom det fanns ett altare med en monstrans måste en grundläggande textil altarskrud också ha funnits, dvs. linneduk, antependium, altarbrun. Den förgyllda monstransen lyckades systrarna sannolikt behålla ända till stängningen 1595, men därefter försvinner den ur källorna. ${ }^{342}$ Huruvida altaret även prytts av kors och ljus är inte känt, men troligt. I stängningsinventariet från 1595 uppräknas flera altarbrun och antependier. Ett noterades vara med guldbroderier, fyra med pärlbroderier och ytterligare sex brun noterades i en grupp för sig. Dessutom fanns tolv antependier, ytterligare tre släta altarbrun samt tre par altarstukor. Tyvärr sägs ingenting om färger, motiv eller mått på de nu uppräknade altartextilierna. Måtten kunde ha gett upplysning om för vilka altaren de var skapade, eftersom Birgitta föreskriver måtten på både högaltaret, de tolv apostlaaltarna och Mariaaltaret. ${ }^{343}$ Flera av de nämnda altartextilierna har gått förlorade sedan 1595, men det finns ett altarbrun kvar som skulle passa bättre in på nunneläktarens altare än något annat altare, SHM 23022:7. (Bild 34.) Det är broderat med nunnornas typiska yttäckande klyvsöm i kombination med guldtråd i läggsöm (det sistnämnda är en teknik som man i inventariet hade noterat för ett av altarbrunen). Brunets nuvarande längd är ca $128 \mathrm{~cm}$, men det uppskattas av Inger Estham till att ha mätt $160 \mathrm{~cm}$ ursprungligen, då det enligt henne saknas en av de tolv förmodade ursprungliga

\footnotetext{
340 SHM 28813 H:5, H: 31:7.

341 Bilder av lerrelieferna se "Bespottandet" SHM 28813 H:5, "Sancta Facies" SHM 28813 H: 31:7.

342 Monstransen nämns inte i inventariet för kyrkan 1598. Sandgren "Prosperity and poverty" 2017 s 245, Silfverstolpe 1895 s 153.

343 Revelationes Extra.kap. 28. Lundén bd IV 1959 s 132-133.
} 


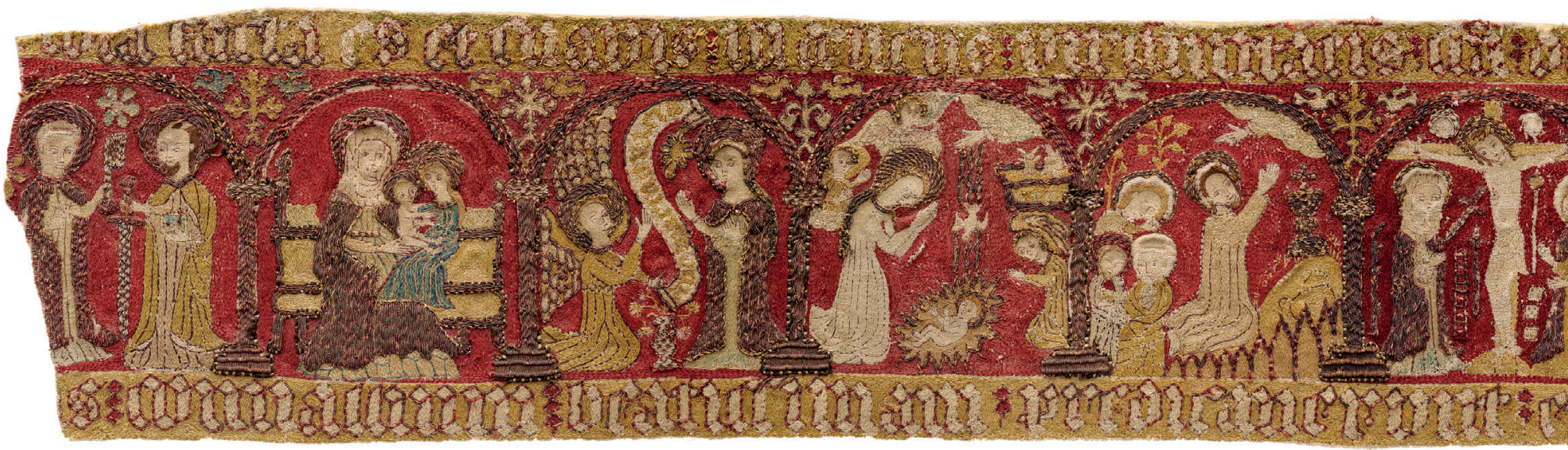

Bild 34. Det helbroderade altarbrunet har elva bevarade scener placerade i rundbågar. Motiven är helgon och ur Jesu liv. Både upptill och nedtill löper en text ur Cantus sororum, en antifon i nunnornas tisdagsliturgi. Broderiet är utfört yttäckande i klyvö̈m på linnelärft. Längd ca $128 \mathrm{~cm}$, höjd ca $17 \mathrm{~cm}$. (C) $S H M$.

figurscenerna. ${ }^{344}$ De bevarade elva scenerna är placerade under rundbågar som är ca 10-11 cm breda vardera, vilket innebär att betydligt mer än en valvbåge saknas för att komma upp i den av Estham föreslagna längden på $160 \mathrm{~cm}$. Det saknas ytterligare en bit även till höger, inte bara till vänster där stympningen är mest påtaglig. En textbård löper utmed hela övre och nedre kanten. Både texten och valvbågen längst till höger är kapade på ett sätt som indikerar en fortsättning, men där har beskärningen gjorts på ett elegantare sätt än i den andra änden. Även texten visar på en stympning i båda ändarna. Det saknas några ord ur liturgicitatet och det sista ordet i övre raden är synbarligen stympat. ${ }^{345}$ Det föreslagna ursprungliga måttet $160 \mathrm{~cm}$ eller ett alternativt mått på $128+12$, dvs. $140 \mathrm{~cm}$ stämmer inte för de altaren som Birgitta föreskrev måtten på. Högaltaret skulle mäta 5x2,5 alnar och Mariaaltaret 4x3 alnar. ${ }^{346}$ Apostlaaltarnas mått på 2,5x1,5 aln ligger närmare till hands, men blir lite för kort. ${ }^{347}$ Både tekniken och formatet pekar mot att altarbrunet varit avsett för ett mindre altare, t.ex. nunneläktarens andaktsaltare.

Ett innehållsligt indicium på altarbrunets hemvist på nunneläktaren är även ikonografin och den omgivande textbården. Motiven är scener ur passionsberättelsen blandad med Jesu barndomshistoria, jungfru Marias liv samt helgonframställningar. Från vänster räknat ses 1) Petrus \& Paulus, 2) Anna själv tredje, 3) Bebådelsen, 4) Födelsen, 5) Getsemane, 6) Korsfästelsen, 7) Gregoriusmässa, 8) den uppståndne Kristus möter jungfru Maria, ${ }^{348}$ 9) Marie kröning, 10) Johannes döparen \& S Birgitta, 11) S Matteus \& S Andreas. Här återfinns med andra ord centrala delar

\footnotetext{
344 Estham 1991 s 22-23.

345 Det som saknas är ...tem in floribus et lilu...

346 Revelationes Extra. kap. 28. Lundén bd IV 1959 s 132-133.

347 Lekmannaaltarnas utsmyckning har eventuellt inte bevarats alls i klostret eftersom det var privategendom som inte tillhörde klostret.

348 Ibland är motivet misstolkat som Jesu möte med Maria Magdalena. (Markus 16:9, Johannes 20:11ff.) Mötet nämns i Revelationes Bok 6 kapitel 94, se Lundén bd III 1958 s 166.
} 


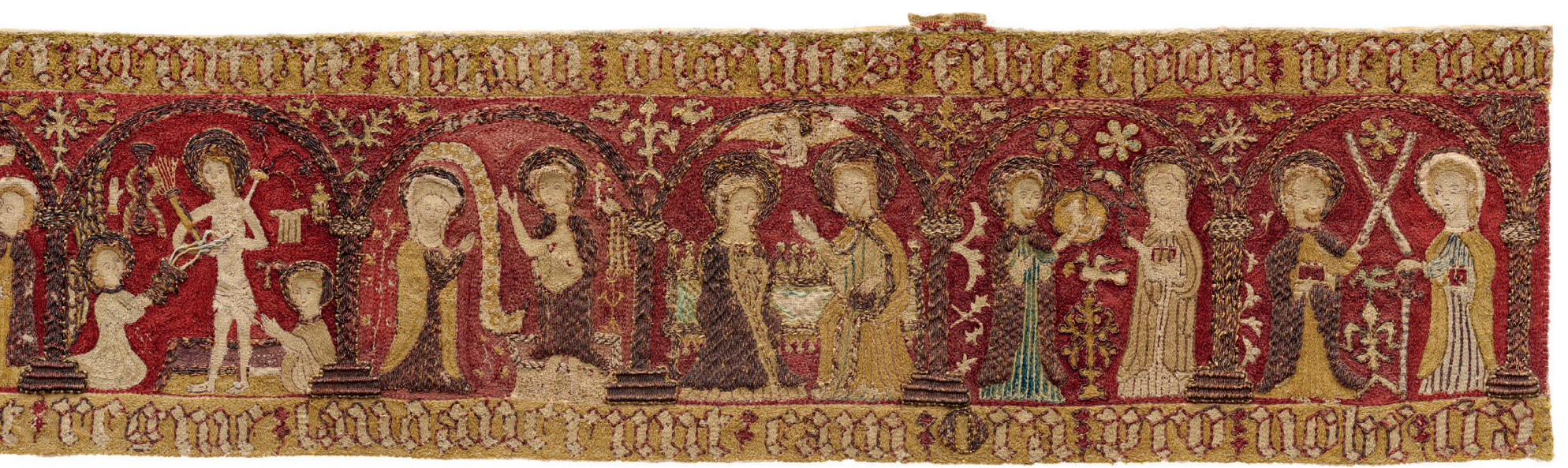

av Kristi passion och jungfru Marias liv tillsammans med några av de viktigare lärjungarna. Ett specifikt birgittinskt motiv är scen nr 8, mötet mellan den uppståndne Kristus och hans mor. För Birgittasystrarna spelade jungfru Marias mor sankta Anna även en central roll och vi ser också det avlatsrelaterade motivet Gregoriusmässan. Kompositionen antyder att Korsfästelsen har varit centralmotivet, flankerat av Getsemanescenen till vänster och Gregoriusmässans överdimensionerade Smärtoman till höger. Det är således troligt att det saknas åtminstone en hel scen på vardera sidan, men det är svårt att gissa vilka scener det kan ha rört sig om. ${ }^{349}$ Stilistiskt hör brunet hemma decennierna kring mitten av 1400-talet, vilket ligger i linje med när man tog den färdigbyggda kyrkan och dess altaren i bruk.

Texten som löper utmed övre och undre kanten på altarbrunet är hämtad från systrarnas liturgi, Cantus sororum, närmare bestämt en Mariaantifon ur tisdagens kompletorium: Speciosa facta es et suavis deliciis virginitatis s[an]c[t]a dei genitrix quam videntes filie syon vernan[tem in floribus rosarum] / [et liliu]s conuallium beatissimam predicauerunt et regine laudauerunt eam. Ora pro nobis s[an]c[t]a [maria]... ${ }^{350}$ Denna marianskt präglade liturgi i klostret sjöngs endast av nunnorna och det är därför rimligt att altarbrunet med denna text använts inom systrarnas klausur, lämpligen på deras eget andaktsaltare. ${ }^{351}$ Kombinationen av text och motivurval skapar en tät birgittinsk kontext med Kristi passion i centrum, omgiven av centrala scener ur Marias liv, varvad av scener som pekar på helgonens och apostlarnas roll i kyrkan, tillsammans inramat av lovsången till jungfru Maria, avslutad med de välkända orden Ora pro nobis sancta Maria. De materiella aspekterna (format, teknik) tillsammans med ikonografi och text, tyder samstämmigt på att brunet varit avsett att brukas på nunneläktarens altare. Placeringen av andaktsaltaret kan också ha förstärkt budskapet genom att det bildade förgrund till Mariaaltaret i öster. Det blir ett laddat blickfång

349 En framställning av Katarina av Vadstena har sannolikt ingått i sviten.

350 Fornsvensk text se Geete, Robert (red.), Jungfru Marie örtagård: Vadstenanunnornas veckoritual, Norstedt, Stockholm, 1895-97 s 76. Estham säger att det är en versikel, men det är en antifon.

351 Altarbrun nr 12 i klostermuseet (Pietas nr 3596) är utfört i samma teknik. Det har scener ur legenden om Marias barndom och bör har hört till antingen ett Anna- eller Mariaaltare. 
för nunnorna att i förgrunden se Kristi lekamen i monstransen på andaktsaltaret, inramat av altarbrunets komprimerade birgittinska budskap, samtidigt som Birgittaskrinet och Mariakorets altare utgör fond i öster.

Ytterligare ett föremål som användes av systrarna var den Mariabild som nämndes i samband med fredagens Botpsalmsprocession. Vilken bild det kan ha varit är inte dokumenterat, men eftersom den var portabel och bars av en person kan den inte ha varit så väldigt stor eller tung. Det är känt att två Mariabilder fick lämna klosterkyrkan på 1540-talet. I räkenskaperna figurerar en Mariabild som 1542 köptes av Gustav Vasas svärmor och syssling, fru Ebba Eriksdotter Vasa (g. Lejonhufvud). ${ }^{352}$ Enligt Vadstenadiariet var kungen själv på besök året efter, 1543, och tog då med sig stenbilden som stod vid jungfru Marie altare. ${ }^{353}$ Båda Mariabilderna kan alltså ha hört till den mer portabla sortens helgonbild, men en stenbild var nog i tyngsta laget att bära runt på. Av de många helgonskulpturer som återges i J. F. Martins bild från den gamla sakristian (före 1816, bild 9) är det få Mariabilder, och de är alla mindre troliga alternativ i detta sammanhang. Bland de Mariabilder som bevarats tills idag finns två intressanta kandidater. Det är dels den Mariabild med sekundärt dorsale som står uppställd i den så kallade kapitelsalen i klostermuseet (bild 35b), ${ }^{354}$ dels den rundskulpterade ("sköna") Madonnan i nischen i kyrkans sydvästra hörn. ${ }^{355}$ Ingen av dem går emellertid att känna igen i Martins bild. Det kan betyda att de inte hörde till klostret vid tiden för Martins bild, utan kom dit i samband med överflyttningen av föremål från S Per 1829. Det kan också innebära att de fortfarande stod uppställda inne i kyrkan och därför inte avbildades i sakristian. (Ytterligare en förklaring skulle kunna vara att Martins bild inte bör tolkas bokstavligt i alla avseenden.)

Kapitelsalens Madonna har ursprungligen inte hört ihop med ryggstycket hon nu står vid, även om dorsalet hör till den typ som förekommer i Vadstena. (Bild 35.) Bildstorleken, $75 \mathrm{~cm}$ hög, skulle vara möjlig för en portabel skulptur. Även dateringen till ca 1400 skulle kunna tala för denna madonnabild. Den skulle i så fall ha prytt nunneläktarens altare under en stor del av klostertiden, och kanske genom sin betydelse skonats från förgängelse. ${ }^{356}$ Det är också tydligt att denna Mariabild prytts av en lös krona. Kronor av pärlor och ädelmetall nämns upprepade gånger i både silverreduktionsprotokollet 1540, räkenskaperna 1539-70 liksom även i inventariet 1595. Med tanke på det lilla formatet på madonnabilden kan hennes förlorade krona knappast ha hört till de brudutstyrslar som kunde lånas från en del altaren. Därmed minskar också sannolikheten att madonnabilden stått på något av lekmannaaltarna.

\footnotetext{
352 Silfverstolpe 1895 s 29.

353 DV 1190. Det finns ytterst få stenskulpturer bevarade men madonnan från Kungs-Husby kyrka ger en god jämförelse, se http://www.himlenarhar.se/foremal/madonnaskulptur-fran-kungshusby-kyrka/. Hon mäter $69 \mathrm{~cm}$ höjd.

354 Dorsalets bas och basen på Mariabilden stämmer ej överens. Andersson 1983 s 25-26.

355 Bild se https://sv.wikipedia.org/wiki/Vadstena_klosterkyrka\#/media/Fil:Madonnan_i_ Vadstena.JPG.

356 En mindre madonnabild förlorades i samband med en brand redan 1388, DV 47.
} 
Bild 35. Stående jung fru Maria med Jesusbarnet. Träskulptur från ca 1400 , troligen nordtyskt arbete. Höjd $70 \mathrm{~cm}$.

Ryggstyckets höjd $123 \mathrm{~cm}$. Skulpturgruppen är sekundärt placerad vid dorsalet och försedd med modern krona. Foto förf.

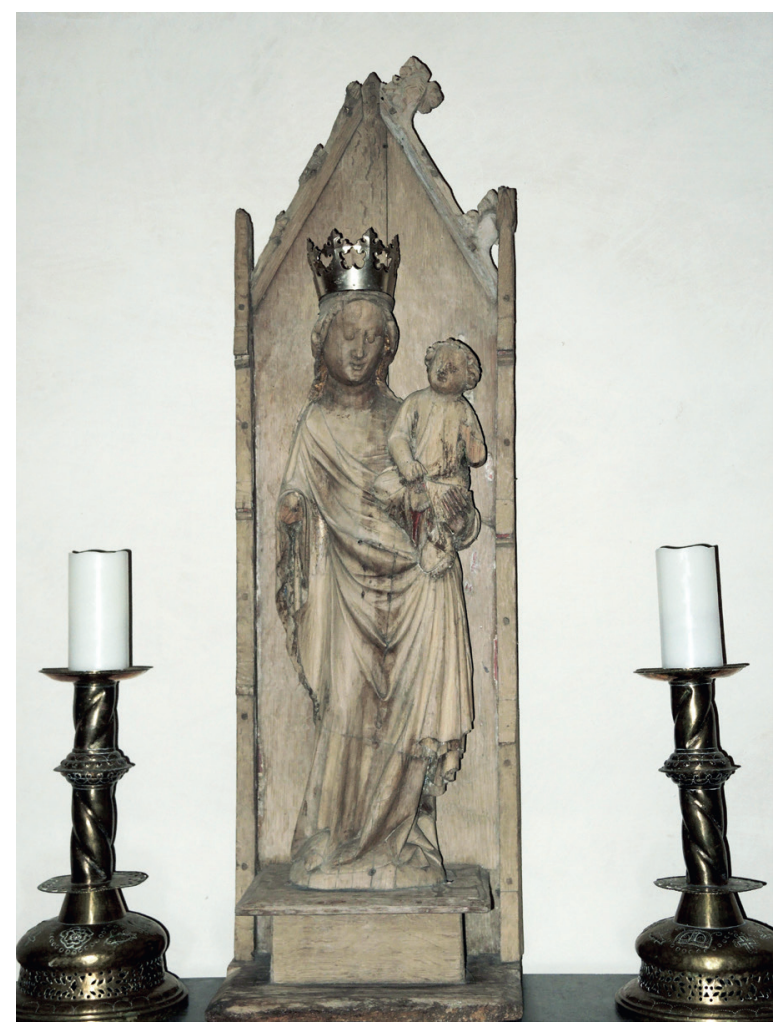

Ytterligare ett föremål i 1595 års inventarium hör samman med en betydelsefull skulptur och det är den så kallade beläteskjorteln. Det var en påkostad dräkt som man klädde medeltida skulpturer i, särskilt i samband med högtidsdagar. ${ }^{357}$ Inventariet omtalar den som liten, vilket gör att den kan ha hört till ett Jesusbarn eller en mindre madonnabild. Den dokumenterade skulpturdräkten, madonnabildens mindre format och dateringen av skulpturen är aspekter som talar för att madonnabilden i klostermuseets kapitelsal skulle kunna vara den bild som nunnorna bar med sig i fredagsprocessionen.

Oavsett vilken bild av den heliga jungfrun som prytt systrarnas andaktsaltare, så har det alltså funnits en Mariabild där, tillsammans med monstransen. Förmodligen har skulpturen klätts på med extra fina kläder och huvudprydnad inför helgdagar. ${ }^{358}$ Både kläder och krona tycks ha hört till de saker som bevarades till slutet, eftersom de och processionsbärandet av Mariabilden ingick i den regelbundna liturgiska praktiken. ${ }^{359}$ Föremålen var dessutom laddade med stort affektionsvärde för nunnorna.

357 Dräkter till skulpturer noterades i flera kyrkor i samband med silverskatten 1540 enligt Källtröms förteckning 1939. För bevarade tyska exempel på skulpturdräktbruket se KlackEitzen, Charlotte, Ortlepp, Wiebke \& Weissgraf, Tanja, Heilige Röcke: Kleider für Skulpturen in Kloster Wienhausen, Schnell \& Steiner, Regensburg, 2013.

358 Det är mindre troligt att andaktsaltaret prytts av ett altarskåp med flyglar eftersom de skulle ha skymt Birgittaskrinet och Mariaaltaret för systrarna.

359 Sandgren ”Prosperity and poverty" 2017 s 248. 


\section{Bilderna i nunnornas liturgi}

Madonnabilden som bars med i nunnornas fredagsprocession var viktig för deras andaktsliv. Det var en bild som fanns i deras omedelbara närmiljö, som de såg varje gång de var i koret, medan de flesta andra altaren med helgonbilder i kyrkan endast kunde ses på håll, om de ens syntes från nunneläktaren. Inom nunnornas blickfång och upphöjd över golvet stod också Mariaaltaret i öster. Av Gustav Vasas agerande 1543 vet vi att även där stod en Mariabild, men av sten. Andra dokument nämner även den hängande Mariabilden i kyrkans tak, troligen någonstans över västra delen av nunneläktaren. ${ }^{360}$ Det innebär att systrarna hade tre Mariaskulpturer inom synhåll från sina korstolar. Även i konventstugan, dvs. arbetsrummet, fanns ett altare med en Mariabild. ${ }^{361}$ Förebilden jungfru Maria var således ständigt närvarande för deras blickar, vart de än vände sig. I sina bönböcker kunde en del av nunnorna även låta blicken vila på Mariabilder, som Ingegerd Ambjörnsdotter (A 43) och Birgitta Andersdotter (A 80).

Mycket av innehållet i bönböcker och tideböcker upptogs av böner till Kristus och Maria, men i de bildlösa Cantus sororum-handskrifterna var Marias närvaro ännu mer påtaglig genom själva texten. Där handlade varje dag om olika aspekter av jungfru Maria och hennes roll i frälsningshistorien, och systrarna lovsjöng henne som sin och heliga Birgittas främsta förebild. Till och med söndagens trinitariska tema är vinklat med ett Mariaperspektiv. Men det är inte Maria som intagit Treenighetens plats utan man kan, som Alf Härdelin uttrycker det, säga att "Grundlinjen är ... den trinitariskt-frälsningshistoriska, och i den är sedan den marianska infogad." ${ }^{662} \mathrm{De}$ olika veckodagarnas Mariateman märks inte bara genom antifonernas och hymnernas texter utan även i de mindre liturgiska detaljerna. Det genomsyrar hela liturgin. Delar av liturgin är specialskrivna texter, men även om de är nya skapelser så är de ofta baserade på äldre liturgiskt material. ${ }^{363}$ På sätt och vis kan man säga att hela Cantus sororum är baserat på det Mariaofficium som var kärnan i de senmedeltida tideböckerna, Jungfru Marie tidegärd. ${ }^{364}$ På samma sätt som Marie tidegärd har ett fast dagligt program oavsett veckodag eller kyrkokalender, så har Cantus sororum ett fast veckoschema, oavsett kyrkokalenderns varierande festgrader för olika dagar under året. ${ }^{365}$

I samband med handskrifternas bildprogram nämndes att Marie tidegärd hörde till de medeltida texter som hade fast etablerade bildtraditioner och vanligen skildrade Jesu barndomshistoria. Ett sådant bildprogram framställs i de nämnda

360 SDHK 28576 nämner invigningen av Mariabilden. RA ms A 19 f. $125 \mathrm{r}$ nämner att Mariabilden hängde. Silfverstolpe 1895 uppger att den hängde mitt i taket, s 43.

${ }^{361}$ Klemming 1883-84 s 70.

362 Härdelin 1998 s 10.

363 Strinnholm Lagergren, Karin, Birgittine chantscape. Chant and liturgy in the Order of the Birgittines 14th-20th centuries, isht Introduction, Chapter 1. Ges ut 2022.

${ }^{364}$ Härdelin 1998 s 8-9.

${ }^{365}$ För vidare läsning om nunnornas liturgi och musiken i den, se Karin Strinnholm Lagergrens kommande studie. 
kalkmålningarna i Folkungapalatsets bottenvåning, på Birgittaaltarskåpets vänstra dörrinsida samt på dörrarna till det Mariaaltarskåp som Vadstena kloster bytte bort till Norra Fågelås kyrka. ${ }^{366}$ Det var en känd bildkonvention även i Sverige och kunde mycket väl ha utnyttjats av magister Petrus och heliga Birgitta för att skapa tematiken i Cantus sororum, men kopplingen till bildprogrammet i Marie tidegärd är mycket svag. Motiven i jungfru Marie tidegärd inleds av Bebådelsen, därefter följer Marias och Elisabets möte, Jesu födelse, Budskapet till herdarna, Konungarnas tillbedjan, ${ }^{367}$ Frambärandet i templet, Flykten till Egypten samt slutligen Marie himmelska kröning. I Cantus sororum återfinns Jesu födelse i torsdagens tema, och på lördagen Marias himmelska upphöjelse, i paritet med den himmelska kröningen i Marie tidegärds kompletorium. Övriga teman i Cantus sororum stämmer inte alls med ikonografin för Marie tidegärd. Dessutom, medan Marie tidegärd upprepas dagligen är Cantus sororum som sagt uppbyggd på veckobaserad upprepning.

På söndagen, dvs. veckans första dag, är det Treenigheten som står i centrum i Cantus sororum. Detta stämmer också bra överens med att Treenighetstidegärden ingår i nunnornas andra bön- och tideböcker, i några dessutom som första officium. ${ }^{368}$ I bönböckerna C 12, A 43 och A 80 har man till och med den svenska versionen av officiet. Kopplingen mellan det trinitariska temat i liturgin och den visuella kontexten yttrar sig inte i några bevarade kultbilder av Nådastolen, det kanske mest typiska treenighetsmotivet under senmedeltiden. Det fanns dock ett Trefaldighetsaltare i lekmannadelen av kyrkan, grundat av Gustav Anundsson Sture (d. 1444). ${ }^{369}$ I Martins bild (bild 9) ovan finns emellertid inget som kan tolkas som en Nådastol eller treenighetsbild. De motivexempel från klostret som finns kvar är en broderad besättning (SHM 23022: 8d), miniatyren i breviariet A 36, samt den ovala (förlorade) marginalbilden som sannolikt inledde officiet i bönboken $C 12 .{ }^{370}$ Det är troligt att motivet inlett även trefaldighetsofficierna i handskrifterna Gießen 881 (f. 72v), A 80 (f. 81v) och Berlin Theol oct 71 (f. 95v). ${ }^{371}$

Måndagens tema i systrarnas tidegärd handlar om änglarnas glädje över Maria som Jesu blivande mor, och tisdagens tema handlar om profeternas glädje över Maria och hennes roll som den fallna skapelsens beskyddare. ${ }^{372}$ En bokstavlig tolkning är att söka i bildmaterialet efter änglar och profeter, vilket visar sig svårt att finna. Men det finns ett intressant undantag: En av skulpturerna av Anna själv tredje har en femkantig reliefskuren sockel där två musicerande änglar dekorerar frontsidan,

\footnotetext{
366 Foton av Norra Fågelåsskåpet se https://kmb.raa.se/cocoon/bild/kont-811a43535e156f3a0d142 b05507232420c447b04?form_name=searchresult\&form_action=noop\&offset=91.

367 Rester av detta motiv finns i två nischer i västra koret i Maribo enligt Norn 1948 s 55.

368 Första officium i bl.a. Berlin 71, Gießen 881, C 12, E 9068.

369 Källström 1939 s 284.

370 Miniatyren i A 36 inleder treenighetsofficiet. Även i denna handskrift finns spår av liten förlorad inledande bild fol. 1r. Se Hedström 2009 s 414.

371 Folio 95 i Berlinbönboken har spår efter lim nålhål från en fastsydd bild på den tomma versosidan mittemot den inledande texten.

372 Geete 1895-1897 s LI-LII.
} 


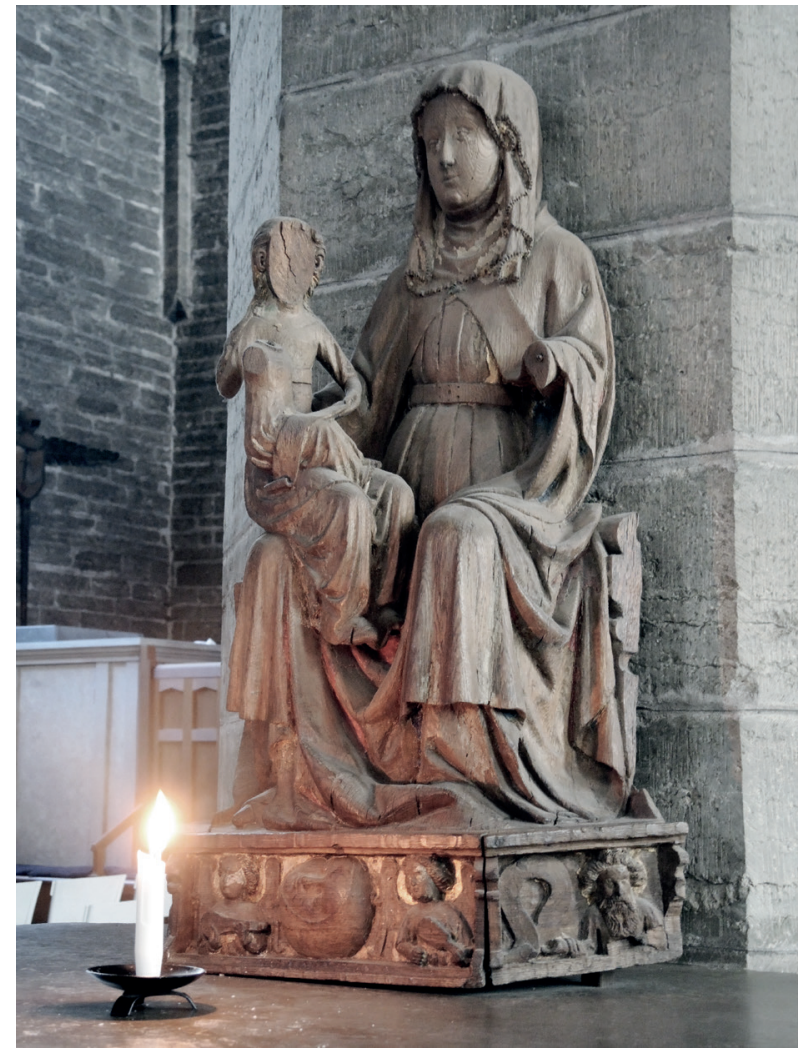

Bild 36. Anna själv tredje. En av de tre skulpturgrupperna $i$ klosterkyrkan med detta motiv. Denna dateras till första halvan av 1400-talet och anses vara ett nordtyskt arbete. Basen är försedd med reliefer av änglar, profeter och månen. Höjd $99 \mathrm{~cm}$. Foto förf.

flankerade av fyra profeter på vardera sidan. ${ }^{373}$ (Bild 36.) Bilden förenar på så sätt både änglarnas och profeternas prisande av jungfru Maria, presenterad i sin moders knä tillsammans med Sonen. - Ett nog så birgittinskt bildtema!

Onsdagens tema i Cantus sororum, Marie födelse och barndom, är lättare att återfinna i bildmaterialet från Vadstena, inte minst i altartextilierna. Enligt källorna skall det ha funnits minst tre Anna-altaren i kyrkan, vilket svarar mot de tre bevarade skulpturerna av Anna själv tredje. Något mer passande att pryda dessa Anna-altaren med än Anna- och Joakimlegenden är svårt att tänka sig. Den under senmedeltiden så populära legenden om Marias föräldrar, Anna och Joakim, framställs i två av de broderade altarbrunen, och där ingår även Marie födelse bland scenerna. De tre skulpturgrupperna med Anna själv tredje kan naturligtvis också räknas in i den ikonografiska kontexten kring jungfru Marie barndom/födelse, även om det också är ett självständigt motiv.

Generellt sett vanligare i konsthistorien är torsdagens tema: Jesu födelse. Det var även ett motiv som den heliga Birgitta kom att påverka genom Uppenbarelserna. ${ }^{374}$ Födelsen ses inte bara i de nämnda kalkmålningarna i kapitelsalen och på Birgittaaltarskåpet, utan ingår också i de två nämnda altarbrunen med legenden om Anna

373 Endast tre profeter är bevarade.

374 Se Cornell, Henrik, The Iconography of the Nativity of Christ, Lundequistska bokhandeln, Uppsala 1924. 


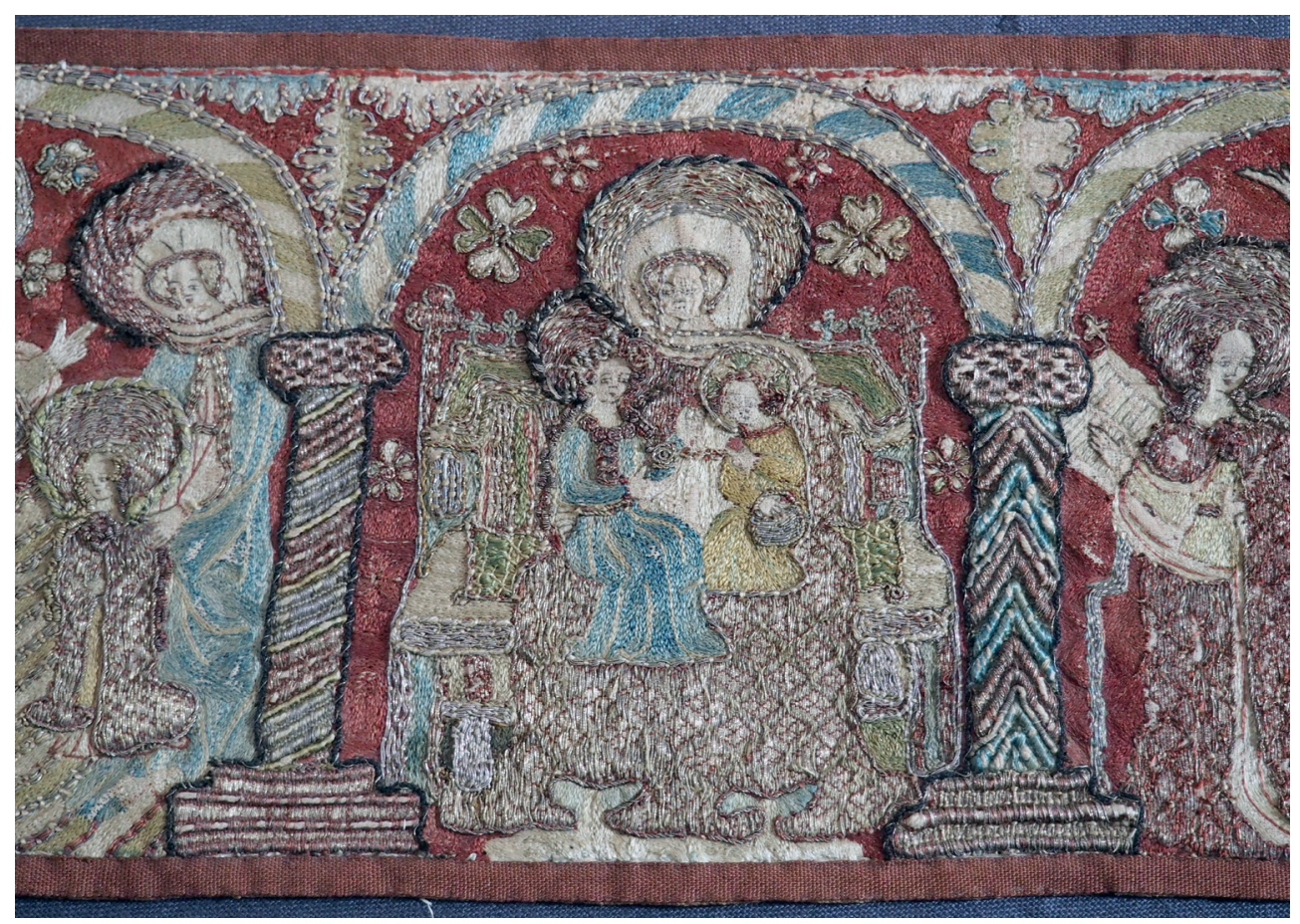

Bild 37. Anna själv tredje. Detalj av altarbrun med scener hämtade ur legenden om Anna och Joakim, ur Jesu barndomshistoria, samt helgon och Mater dolorosa. I mitten en kalvariescen. Längst till höger helgon, parvis framställda under bågar: S Petrus E S Sohannes, S Katarina av Alexandria E' S Birgitta. Helbroderad med silkestråd $i$ klyvsöm på linnelärft. Längd 166,5 cm, höjd 17,5 cm. Vadstena klosterkyrka. Foto förf.

och Joakim. (Bild 37.) Ett av de äldsta textila verken från klostret innehåller också Jesu födelse, altarbrunet i Linköpings domkyrka. Det finns däremot inga spår av att motivet ingått i någon av systrarnas bevarade bönböcker. Det finns exempelvis inte heller svenska medeltida böner som har Jesu födelse som tema. ${ }^{375}$

Desto mer på modet inom cura monialum, nunnornas andliga fostran, och allmän senmedeltida spiritualitet var passionsfromheten. Olika aspekter på Jesu lidande var ett tema som kunde varieras i det till synes oändliga. Fredagen var sedan länge en bot- och fastedag med koppling till långfredagen. Varje fredag är en "minilångfredag" och därför präglad av fasta, bot och åminnelse av Jesu lidande. ${ }^{376}$ Därför utfördes den tidigare diskuterade botpsalmsliturgin den dagen i veckan. Att Cantus sororum har Jesu lidande som tema för fredagen är därför naturligt. I den birgittinska tappningen är passionen framställd ur jungfru Marias perspektiv. Det tredje responsoriet i fredagens matutin är till och med framställt som en ögonvittnesskildring av hur Maria upplever sonens lidande, och hur hon själv samtidigt lider med honom. ${ }^{377}$ Det som framställs i Cantus sororum-texterna är i allra högsta grad passionen, sedd ur hennes synvinkel, dvs. helt i överensstämmelse med skildringarna

\footnotetext{
375 Jfr innehållsförteckningen hos Geete 1907-09.

376 Se Björkman 1957 s 241-315, i synnerhet s $241 \mathrm{ff}$.

377 Transkription av fornsvenska texten se Geete 1895 s 105 ff.
} 
i Uppenbarelserna. En kalvariescen med den sörjande Maria vid korset kan naturligtvis fungera som visuell kanal för detta marianska perspektiv på Jesu lidande, men i Vadstena fanns fler uttryck i överensstämmelse med tidens fromhetsströmningar. Ett populärt motiv var Pietà, och det finns exempel på detta från Vadstena i den tidigare nämnda C 12, ena besättningen av SHM 23022:8 samt det tidigare nämnda altarbrunet i Linköpings domkyrka. Förutom den lilla Pietàn i C 12 har motivet ingått i ytterligare ett par bönböcker. Däremot är någon Pietà från klosterkyrkan inte bevarad eller dokumenterad, trots de många altarna. ${ }^{378}$ Det kring 1500 mycket populära temat Marie smärtor var däremot representerat med ett altare såväl inom som utom klausuren, men hur de varit prydda är inte känt. ${ }^{379}$

Bönerna som handlar om Marie smärtor förekommer i flera av bönböckerna men det är bara i den stora bibelhandskriften A 1 som en bild har bevarats. ${ }^{380}$ (Bild 21.) Den stora kolorerade gravyren inleder hela boken och inramas tillsammans med den motstående första textsidan av en praktfull marginaldekor. I marginaldekoren runt texten finns ytterligare en visuell framställning av hur Jesu lidande och Marias medlidande sammanlänkas: i det sårade hjärtat som försetts med texten fons amoris inuti. Sårade hjärtan med samma text dyker upp i ytterligare ett par handskrifter, C 443 och A $3 .^{381}$ (Bild 22.) Bilden av det sårade hjärtat innebär ett sammanlänkande $\mathrm{i}$ ett reciprokt förhållande mellan Kristus och Maria. Kärlekens källa, fons amoris, är ett uttryck både för Jesu självutlämnande kärlek till mänskligheten, och för Marias kärlek till sonen och hennes självutlämnande kärleksgärning genom att förmedla inkarnationen. Utan Marias "ja” i bebådelsen hade det inte blivit någon inkarnation, och inte heller någon frälsning. I dessa emblematiska andaktsbilder kan den mediterande/bedjande nunnan låta tanken skifta mellan de båda aktörernas lidandefyllda kärleksgärning för mänskligheten och för nunnan själv. ${ }^{382}$ Det är inte bara Kristus som lider utan även hans mor lider fysiskt inför åsynen av sonens lidande. Man kan säga att hjärtbilderna är ett koncentrat av fromheten. Den här täta sammanlänkningen yttrar sig också visuellt i andra sammanhang genom sammanställningar av symboler som förknippas med Jesus och Maria, eller genom att deras namn eller monogram kombineras. Exempel på detta är monogrammen i den övre marginalen av A 2 f. 3r, och det av systrarna broderade mässhakekorset i Skara. (Bild 26.) Till samma samling hör även en stjärnprydd Vadstenatillverkad mässhake med vinranka på ryggkorset, ${ }^{383}$ vilket också är referenser till Maria som den strålande stjärnan och Kristus som vinträdet (Joh. 15:5). Hymnen Ave maris stella ingår i lördagens vesper i Cantus sororum, och i onsdagens laudes och söndagens vesper beskrivs Maria som skeppens och havets stjärna. Även den i klostret tillverkade praktmitran som nu

\footnotetext{
378 En framställning av motivet från Nådendals kloster avbildas i Hausen, Reinhold, Nådendals kyrka och klosterruiner, Amos Andersson förlagsaffär, Helsingfors 1922 s 34 bild 12.

379 Källström 1939 s 282-283.

380 Geete 1907-09 förtecknar nr 124-130 ur Gießen 881, A 37, A 43, A 80, C 23, C 68, E 9068.

381 Sandgren 2011 s 119-140, densamma 2015 s 50-65.

382 Motivet är inte unikt för Vadstena, se t.ex. Haag KB ms KA 31 f. 302r.

383 Mässhaken hör till Skara domkyrka och ingår i Västergötlands museums samlingar, se https://digitaltmuseum.se/021027136528/masshake.
} 
tillhör Västerås domkyrka kombinerar symboler för Maria och Kristus, i detta fall med enhörningar och pelikan. ${ }^{384}$

Lördagen är den sista veckodagen i den kyrkliga kalendern. I den birgittinska liturgin handlar temat om Marie himmelsfärd. Jungfru Maria hedrades på detta sätt för sin ödmjukhets skull, att hon som den första kristna människan upptogs till himmelen och till en plats närmast Treenigheten. Vid både non och kompletorium på lördagarna sjunger systrarna Salve regina, en lovprisning till himlarnas drottning. Men det är inte ett veckoavslut som mynnar enbart i förhoppningen om samma himmelska lycka för nunnorna, utan texterna binder ihop inkarnationen, Kristi uppståndelse och himmelsfärd, och eukaristin. Mässoffret är den fortsatta Kristusnärvaron ända till tidens slut, upprepad genom prästernas oupphörliga konsekration. Att knyta ihop lördagens tema på detta sätt är ett synnerligen passande avslut på nunnornas liturgiska vecka, där veckorutinen innebar att lördagen var deras kommunionsdag. ${ }^{385}$ Marie himmelsfärd förefaller emellertid inte ha ingått i bönböckernas bildrepertoar i Vadstena förutom möjligen i C 68 (f. 111v.) Bland de många lekmannaaltarna fanns inte heller något som var helgat till denna fest. Däremot ses motivet på en f.d. korsbesättning till en mässhake i Skara domkyrka, tillverkad av nunnorna. (Bild 38.) Marie himmelska kröning ingår som nämnts i bildprogrammen för Jesu barndomssviter. Nunnorna kunde därför se motivet i det rum som idag benämns kapitelsalen, medan lekfolket kunde se det på Birgittaaltarskåpets vänstra insida.

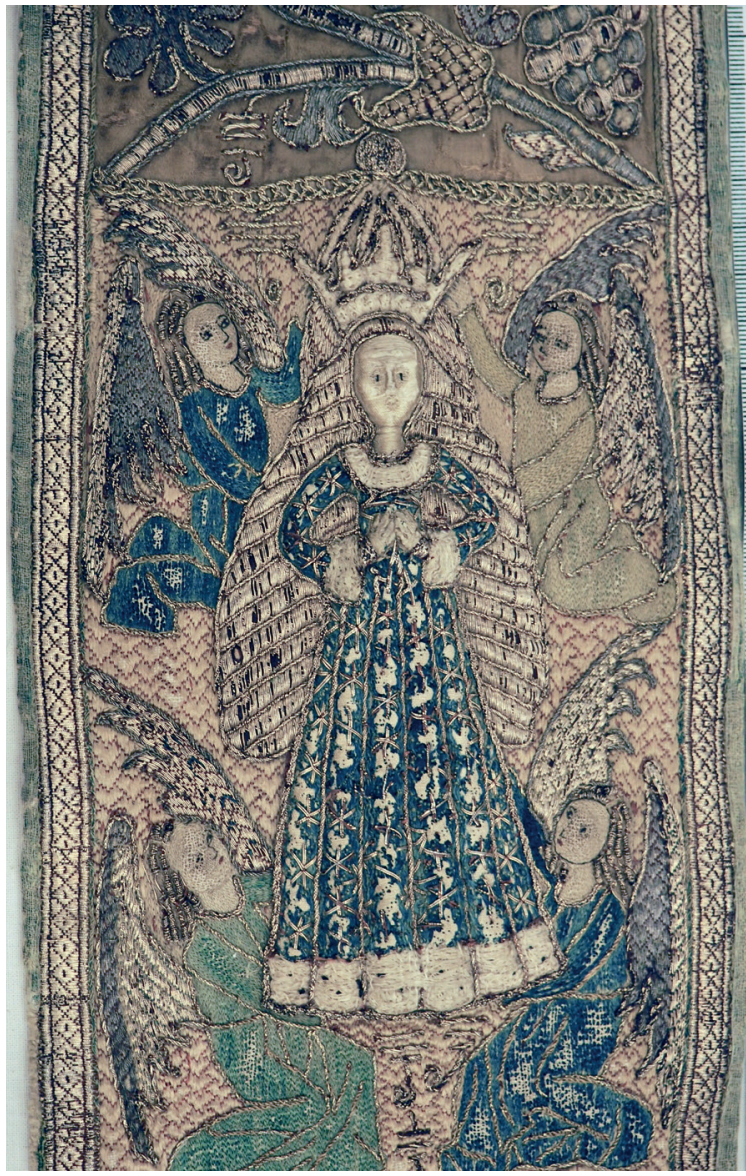

Bild 38. Detalj av bård med jungfru Marias bimmelska upptagning. Maria kröns av en stor sluten pärlkrona och ledsagas av fyra änglar. Broderiet har troligen utg jort ett mässhakskors och är utfört mot tidigare röd sidenbotten och i läggsöm av guld-och silvertråd samt klyvsöm. Jung fru Maria är utförd i reliefbroderi medan änglarna är gjorda i platt klyvsöm. De vita fälten indikerar att sötvattenspärlor en gång prytt bla hennes krona och klänning. Lägg märke till hjärtformerna i bakgrundens läggsöm. Bredd 14,5 cm, höjd ca $121 \mathrm{~cm}$. Västergötlands museum, Inv.nr 1501. Foto förf.

Mariamotiven har såldes en tydlig plats i nunnornas spiritualitet. Förutom de redan nämnda veckodagstemana finns andra Mariamotiv som kan knytas till populära andaktsformer. Framträdande är Rosenkransmadonnan och den Apokalyptiska madonnan. På samma sätt som himmelsfärdens Maria framställs omgiven av strålglans, som i Skarabroderiet, gör även den Apokalyptiska madonnan och

\footnotetext{
384 Två av klostrets prästbröder valdes till biskopar i Västerås stift vid 1400-talets mitt. Mitran anses vara gjord för någon av dem tillsammans med några mässkrudar. Bilder se https://commons.wikimedia.org/w/index.php?title=Category:V\%C3\%A4ster\%C3\%A 5s _ domkyrka\&filefrom=V\%C3\%A4ster\%C3\%A5s+Domkyrka+-+KMB+-+16001000254724.jpg\# /media/File:V\%C3\%A4ster\%C3\%A5s_Domkyrka_-_KMB_-_16001000256764.jpg.

385 Regula Salvatoris kap.18. Lundén bd IV 1959 s 28.
} 
Rosenkransmadonnan. Inspirationen till den Apokalyptiska madonnan är hämtad ur Johannes uppenbarelse 12:1, där en kvinna framträder strålande som solen, med en krona av stjärnor och stående på månskäran. Under senmedeltiden var motivet förknippat med dogmen om Marie obefläckade avlelse samt en omfattande avlat, utfärdad av påve Sixtus IV (1471-84). Den Apokalyptiska madonnan blev därefter ett mycket populärt motiv, kanske delvis tack vare löftet om ända upp till 11000 års avlat för den som läste den specificerade bönen inför hennes bild. ${ }^{386}$ Bönen förekommer i flera av Vadstenabönböckerna och i ett par fall har en bild uppenbarligen ledsagat bönen (C 12 f. 163v, A 80 f. 193v). Bland de liturgiska föremålen i Vadstena återfinns motivet på en besättning (SHM 23022: 8), ${ }^{387}$ en träskulptur på norrväggen i kyrkan, ett förgyllt litet hänge (SHM 8813: E:13) och två broderade altarbrun. ${ }^{388}$ (SHM 13647 samt ett brun i klostermuseet, bild 39). Det finns däremot ingen textdokumentation om något lekmannaaltare helgat åt den Apokalyptiska madonnan. Av bildernas antal att döma har den avlatsförknippade bönen lästs av såväl klosterfolket som lekfolket i kyrkan.

Rosenkransandakten var en andakt som fick en enorm spridning under senmedeltiden och förknippas med en bildframställning med Maria omgiven av ett pärlband med fem rosor. Både Rosenkransmadonnan och Marie smärtor var representerade med två altaren vardera i klosterkyrkan. Det fanns ett Rosenkransaltare på vardera sidan av klausurgränsen enligt reduktionsprotokollet 1540, och likaså dubbel uppsättning av Marie smärtors altare. Det Rosenkransaltare som fanns inom klausuren fick lämna ifrån sig en värdefull krona eller krans i samband med silverreduktionen. Det innebär att det var en madonnabild med en lös krona av ädelmetall. Med tanke på det lilla formatet på det bevarade Rosenkransskåpets Maria kan det knappast ha varit hon som burit den dyrbara krona som nämns 1540 . Klosterfolkets Rosenkransmadonna borde dessutom ha inramats av en krans med sex dekader istället för de i andra rosenkransar vanliga fem dekaderna. ${ }^{389}$

Konsthistorikern Andreas Lindblom anser att ett av Marie smärtors altare grundades av Vadstenaborgmästaren Erengisle Eskilsson, vilket i så fall innebär att det skedde vid mitten av 1400-talet. ${ }^{390}$ En sådan datering skulle vara förhållandevis tidig med tanke på motivets popularisering just decennierna närmast sekelskiftet $1500 .{ }^{391} \mathrm{Om}$ klostrets och lekmännens Marie smärtors altaren prytts av bilder med just detta specifika Mariamotiv, är inte känt. Som konstaterades ovan i samband

\footnotetext{
386 I A 80 står det 4000 istället för 11000 års avlat.

387 Bild se SHM: mis.historiska.se/mis/sok/fyndlokal.asp?lokalid=41045\&in=1\&show=\&samlomr $=4 \&$ npage $=8 \&$ tabpage $=3$

388 Altarbrunet har tillhört Norrsunda kyrka (Up), men broderierna har tillverkats i klostret.

389 En birgittinsk rosenkrans har sex dekader. Rosenkransmadonnan från Maribo har dock fem dekader, en för vardera av Kristi sår.

390 Lindblom 1965 s 237. Borgmästaren är känd t.ex. åren $1444 \& 1450$ genom diplomen SDHK $24550 \& 25687$.

391 Schuler, Carol, M., "The Seven Sorrows of the Virgin: Popular Culture and Cultic Imagery in Pre-Reformation Europe", Simiolus: Netherlands Quarterly for the History of Art, Vol. 21, No. 1/2 1992, s. 5-28.
} 


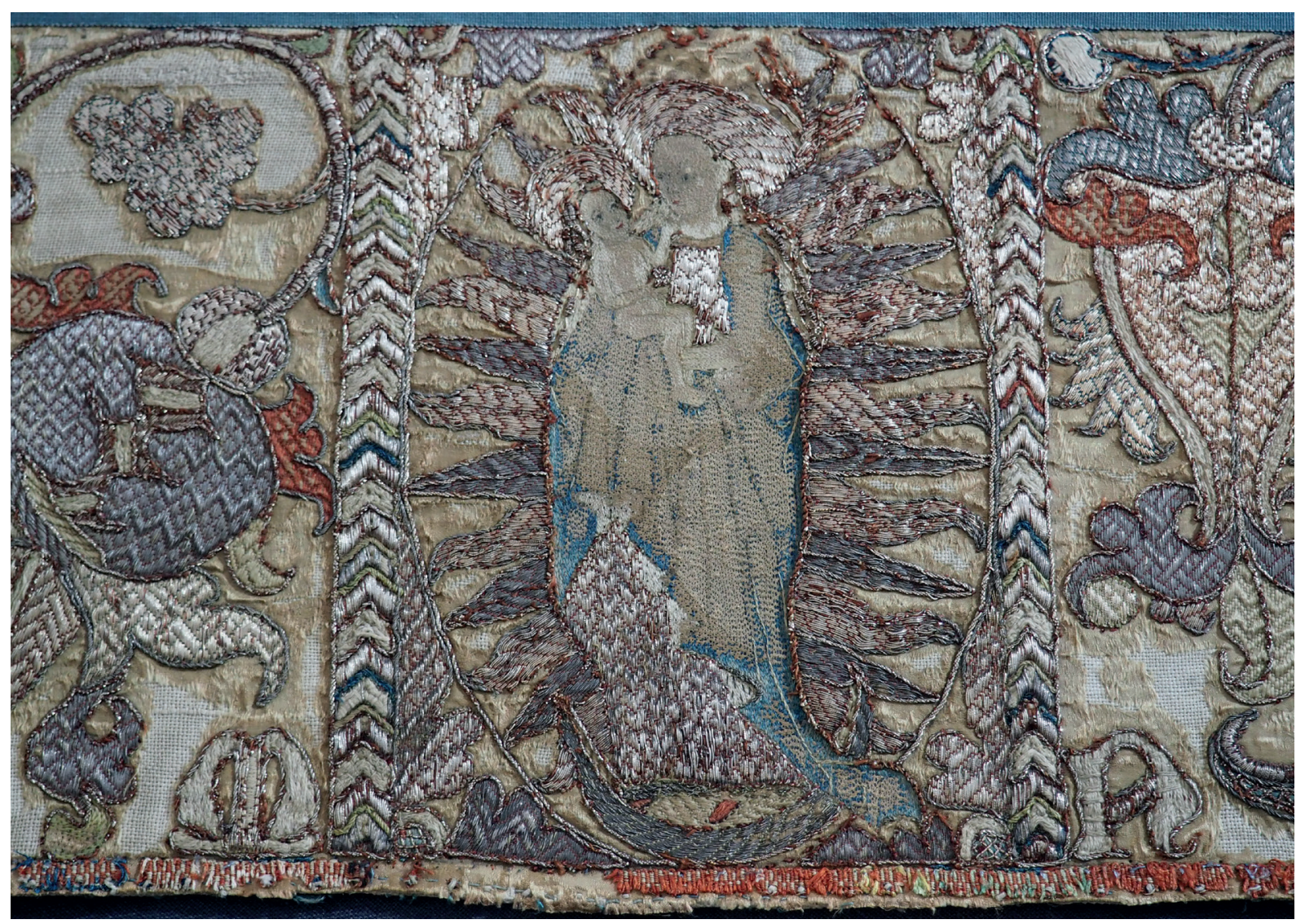

Bild 39. Detalj frän mittpartiet av ett broderat altarbrun med slingrande liljemotiv och en centralt placerad apokalyptisk madonna. Hon omges av strålar i guld och silver och står mellan ett par ornamenterade kolonner. Broderiet är utfört på en tidigare röd sidendamast och huvudsakligen i läggsöm i en mängd olika variationer, men Marias blå mantel och karnationen är utförd i klyvsöm. Vita partier har prytts av sötvattenspärlor. Även större metall- eller stenornament har prytt slingorna. Lägg märke till hjärtformerna i Marias kjortel. Vadstena klostermuseum. Foto förf.

med fredagens liturgi, har inte heller någon pietàskulptur/altarbild bevarats eller dokumenterats i Vadstena, enbart ett träsnitt i C 12 (bild 28).

Som nämndes i samband med handskrifterna ovan framställs Marie smärtor i A 1 (bild 21). ${ }^{392}$ Det är i nunnornas bönböcker som populariteten hos såväl Rosenkransmadonnan som Marie smärtor bevarats. Förutom den mycket rikt dekorerade A 80 är det i tre av bönböckerna (C 12, C 68, och Berlin Theol oct 71), som man kan se spår av bilder till dessa båda andaktsteman. A 80 har bildlakuner vid texterna som passar för såväl en apokalyptisk madonna (f. 193v) som en pietà och/eller Marie smärtor (f. 130v, 200v). Den praktfulla Mariesmärtorsbilden i A 1 ingår dock inte i någon bönbok utan i en högläsningsbok. Den kunde bara betraktas av den syster som skötte högläsningen.

\footnotetext{
392 Se Sandgren 2011.
} 


\section{Ströornament och marginalia i handskrifter och textilier}

Heliga Birgitta tillät som sagt inte rent dekorativa utsmyckningar i kyrkorummet, men trots det har man funnit dekorslingor längsmed valvribborna i kyrkan, och en del av dem kan man se än idag. Huruvida det även funnits andra bilder eller ornament på de nu renknackade väggarna går inte att säga, men det är troligt att någon form av bildskrud prytt interiören. En medeltida kyrka utan något väggmåleri alls är föga troligt. Bildförbudet i klosterregeln gällde inte skildringar av Kristi passion och helgonens liv, och då fanns det en minst sagt bred repertoar kvar att ösa ur. (I Mariager finns exempelvis ett kalkmålningsfragment av Kristi korsbärande.) Läktarmålningarnas vapensköldar, som dokumenterades av Elias Brenner på 1600-talet, hör onekligen till den mer dekorativa delen av kyrkans bildskrud som å ena sidan tangerar gränsen för det tillåtna, men som å andra sidan vände sig in mot lekfolkets del av kyrkan.

Trots heliga Birgittas inskränkningar av det dekorativa uttrycket präglas många föremål från Vadstena kloster ändå av en rikedom av ornament, inte minst textilierna. Det är inte bara ytorna som är översållade av broderade, applicerade, ornament. Det är även rikligt med ornament insprängda i figurbroderiernas bildbakgrunder och arkitekturfält. Man skulle kunna tro att textilierna och handskrifterna av Vadstenanunnornas händer präglas av ett gemensamt formspråk, att de exempelvis gärna inspirerats av varandras arbete i den gemensamma arbetsalen. ${ }^{393}$ Men i handskrifterna är det inte samma ornamentala rikedom och inte heller samma typ av dekorationer som i textilierna. Det är i och för sig visuella uttryck som är parallella i tid och från samma geografiska och kulturella kontext, men trots den stilistiska gemenskapen finns det skillnader mellan dekoren i textilier och i handskrifter. I de liturgiska textilierna finns rikligt med franska liljor, rosor och stjärnor. Sturekåpan, relikskrinet och några av mässhakarna i Skara och Linköping är tydliga exempel på detta. Däremot är just dessa mönsterformer sällsynta i handskrifterna. Likaså förekommer granatäpplen, druvklasar, djur och vapensköldar i broderierna, men inte i nunnornas bokmåleri. Bokmåleriets marginalrankor domineras däremot av akantusblad, eklöv, påfågelsfjädrar, liljor/aklejor och där finns även inslag av knutverksornament och hängande hjärtan. Meanderslingorna som inramat en del miniatyrer förekommer inte alls i det textila materialet från Vadstena. Den typ av påfågelsfjädrar som finns i flera handskrifters marginalrankor från 1500-talets början återfinns på undersidan av relikvariet i Linköping, men sällan i textilierna för övrigt. ${ }^{394}$ Till den gemensamma ornamentiken för textilierna och handskrifterna hör akantusblad, liljor, hjärtan och i viss mån knutverksornamentik, liksom eklövsdekor.

Det finns två birgittinskt förknippade ylletäcken som kommer från det småländska Dalhems kyrka. ${ }^{395}$ Båda visar upp figurer placerade i rundlar mot en i rutor uppdelad bakgrund i positiv/negativ effekt, ett intarsialiknande utförande. Ylletäckena

\footnotetext{
393 Estham 1991 argumenterar för denna koppling.

394 Bild se http://mis.historiska.se/mis/sok/include_image_exp.asp?uid=23356 och Nisbeth, Åke \& Estham, Inger, Linköpings domkyrka, 3 Inredning och inventarier, Linköpings domkyrka, Linköping, 2001 s 124, 126.

395 Kyrkan hörde till Linköpingsbiskopen under medeltiden.
} 


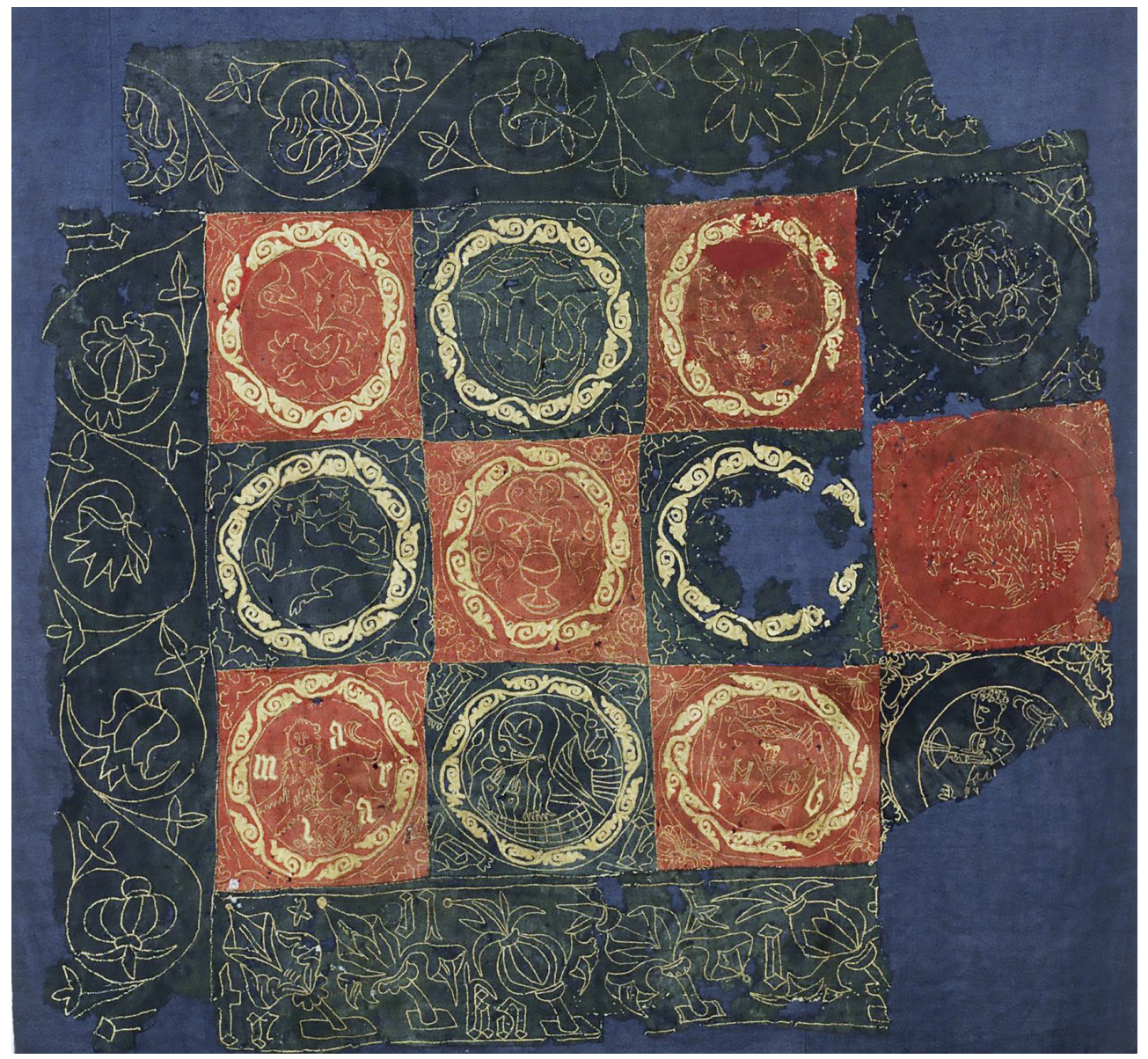

Bild 40. Dalhemstäcket SHM 23022:26 är nästintill kvadratiskt och består idag av tolv fragmentariska rutor med en bred bård. Det är tillverkat i rött och grönt ylle och försett med applicerade vita cirkelformade bladrankor samt konturbroderier i läggsöm. I bården finns blommor, blad och bokstäver som antyder ett marianskt tema. Rundlarnas innehåll är både birgittinskt, marianskt och kristocentriskt. Foto SHM.

anses tillverkade i klostret och kan vara avsedda att fungera som så kallade vesperalen, dvs. skyddsduk/täcke för mässaltare. ${ }^{396}$ Det täcke som är mest intressant ur birgittinskt ikonografiskt perspektiv är det mindre täcket, SHM 23022:26. ${ }^{397}$ (Bild 40.) Dess bildprogram och format pekar mot ett bruk inom klausuren. Dalhemstäckets rundlar är nämligen en sammanställning på temat Kristus - Maria - Birgitta. Pelikanen i nedre raden omges i svicklarna av bokstäverna $b, r, a$ och (troligen) $k$. Bokstäverna $b$ och $k$ kröns vardera av en liten krona, möjligen en referens till Birgittas och Katarinas höga börd. ${ }^{398}$ I rundeln till vänster om pelikanen är ett lejon, vilket

396 Ett vesperale täcker altarets ovansida när altaret inte är dukat för mässa.

397 Täcket mäter nu 164 x $170 \mathrm{~cm}$ och omfattar 12 rutor. Varje ruta mäter $36 \mathrm{~cm}$. Bården är $25 \mathrm{~cm}$ bred och saknas på höger sida. Ursprunglig bredd troligen ca $195 \mathrm{~cm}$, motsv. 3,5 aln. Se katalogkort av Agnes Geijer SHM.

398 I utländsk ikonografi framställs S Birgitta ibland med krona. Kronorna kan även syfta på deras roller i orden. 
kan uppfattas som en Kristusreferens och de runt lejonet utspridda bokstäverna formar namnet Maria. Under lejonets fötter finns även ett hjärta genomborrat av en pil, en referens till Kristi och Marias ömsesidiga lidande. I rundeln över lejonet springer en hjort som troligen jagas av figuren med pilbåge i den fragmentariska rundeln nederst till höger. Till höger om pelikanen ses ett stort bevingat hjärta som genomborras av två korsande pilar. I samma rundel finns också bokstäverna $M, B$ samt $i, a$ och $r$. Kompositionen innehåller även en låg krona placerad över hjärtat. Det finns enstaka exempel på bevingade hjärtan i den profana senmedeltidskonsten men den ikonografiska litteraturen placerar dem inte förrän ett par hundra år senare. Motivet bör i detta sammanhang uppfattas som en anspelning på Kristi lidande, och Marias och Birgittas föredöme som Kristusefterföljare. Vad vingarna mer specifikt spelar för roll är ännu oklart. Mittenraden av rutor innehåller, förutom hjorten, även en örn (längst till höger), ett bortnött motiv samt en prunkande blomsterurna. Vasen/ urnan är framställd som ett genomskinligt kärl och i rutans svicklar ses rosor. Vasen är en Mariareferens, syftande på hennes renhet, den obefläckade avlelsen, medan rosorna kan syfta på både Maria och Birgitta. I den övre raden av rutor återstår blommor i de båda yttre rundlarna och en vapensköld med Kristusmonogram (ibs). Den vänstra blomman är en lilja och den högra har en avhuggen stam/kvist som bas, dessutom med hjärtformade löv i svicklarna. Framställningen symboliserar återigen jungfru Maria och Kristus. ${ }^{399}$ Till höger om vapenskölden ses ytterligare en anspelning på jungfru Maria genom bilden av enhörningen.

Sammanställningen av Dalhemstäckets (SHM 23022: 26) ikonografi gör att den som kan uttyda de laddade symbolerna får ett bildprogram som upprepar jungfru Marias renhet och Jesu frälsningsroll, samt deras intimt förknippade frälsningshistoriska roller, med birgittinska tillägg. Det är ett kateketiskt dogmatiskt koncentrat med birgittinsk vinkling. Lägger vi därtill bokstäverna som placerats på olika ställen över ytan förstärks den birgittinska kontexten. Förutom i täckets rutor och rundlar har bokstäver placerats i bårderna runt kanterna, men det är bara i den undre bården som de är så kompletta att de går att tyda. De bokstäver som går att identifiera är från vänster $t, r, j l$ (?), $k a$ samt ett $i$. Troligtvis har ytterligare bokstäver funnits både till höger och vänster i de nu bortnötta hörnen. Kombinationen av bokstäver pekar i riktning mot Katarina, dvs. heliga Birgittas dotter. Täcket sammanställer alltså den birgittinska fromhetens fokus på jungfru Maria och Kristus, men genom att rama in den i ljuset av Birgittas och Katarinas efterföljelse. Ett sådant bildprogram passar väl in på ett klosteraltare, men det är i minsta laget för att täcka högaltaret eller Mariakorets altare.

Det var ju nunnorna som tillverkade både handskrifter och textilier, medan bröderna var de som bar de liturgiska dräkterna på sig och hanterade de liturgiska föremålen. I många fall kräver ornamentiken att man kan se handskrifterna eller de textila föremålen på nära håll, för att man ska kunna uppfatta den. För lekfolket var det en otillgänglig del av kyrkans bildvärld. Det var en bildsfär som skapades av och för klosterfolket och i synnerhet nunnorna. Det är fascinerande att se hur systrarna

399 Den avhuggna stammen syftar på Kristusprofetian om Isais avhuggna stam, Jesaja 11:1. 
förmår skapa så budskapsladdade föremål genom att "bara" använda dekorativa element ur en allmän medeltida bildrepertoar. Deras förmåga att sätta samman dekorelementen till en birgittinsk läsning är raffinerad och konsekvent ned i detaljerna, och det finns troligen mer att upptäcka i tolkningen av denna ornamentik.

Det vore troligen fel att tolka denna ikonografi på detaljnivå som ett uttryck för explicit individuell bön, som diskuterats av bl.a. Jeffrey Hamburger och Laura Skinnebach m.fl. i snarlika exempel, även om det kan finnas sådana inslag i den monastiska miljön. Arbetet i Vadstena utfördes nämligen i det gemensamma arbetsrummet, ofta under högläsning ur uppbyggliga verk. Snarare än en aktiv individuell bön kan skapandet uppfattas som ett meditativt inslag under lyssnandet. Det går utmärkt att utföra repetitiva handarbetsmoment medan man lyssnar till något.

Ornamentiken innehåller även bokstäver/initialer, som i Dalhemstäcket ovan, men de är vanligare i handskrifterna än textilierna. Tidigare nämndes att förekomsten av skrivarsignaturer i handskrifterna ibland har använts som stöd för att textiliernas bokstäver på motsvarande sätt syftar på brodösen, men i de flesta fall är det tveksamt. ${ }^{400}$ Merparten av de bokstäver som ingår i dekoren skall inte alls uppfattas som signaturer, utan syftar snarare på jungfru Maria, heliga Birgitta och dottern Katarina. Detta är framför allt tydligt i textilierna, där det annars blir vä1digt många Birgitta Andersdotter och Ingegerd Ambjörnsdotter istället för heliga Birgitta och jungfru Maria. I vissa handskrifter är det som vi sett, onekligen skriverskan, t.ex. Christina Hansdotter (Brask) eller Anna Svensdotter, som lämnat sina signaturer, ibland tillsammans med önskan om bönboksägarinnans förbön som i A 80. Anspelningarna på jungfru Maria görs så frekvent i materialet och är helt i linje med den marianska birgittinska fromheten. ${ }^{401}$ Dalhemstäcket ovan är ett ovanligt tydligt exempel på hur bokstäverna har med spiritualiteten att göra, inte hantverkarens identitet. Medan IHS-monogramet var en etablerad nomina sacraförkortning för Jesu namn kunde de medeltida förkortningarna för Maria variera. Maja är ju en kortform av Maria och eftersom det medeltida skriftbruket inte skiljer mellan $i$ och $j$, är det lätt att göra Maria till ma[r]ia. Ibland kunde det räcka med bokstäverna $M A$, som på ryggskölden i Skara eller altarbrunet med den Apokalyptiska madonnan i bild 39 ovan. Andra gånger formade man ett vackert Mariamonogram som flätar samman alla bokstäverna, som i mässhakekorset i Skara (bild 26), kalken från Maribo klosterkyrka och i den övre marginalen av A 2 fol. 3r.

Att göra kombinerade referenser till Kristus och Maria är inte specifikt för Vadstena kloster utan hör hemma i den senmedeltida spiritualiteten generellt sett, men det förefaller som om man renodlat detta spår i den birgittinska kontexten. Sammanställningarna av Maria- och Kristussymboler är så genomgående i bildmaterialet att det ser ut som en medveten strategi. Tidigare nämndes Västeråsmitran med enhörningar och pelikan, ${ }^{402}$ och ett liknande exempel är altarbrunet från

\footnotetext{
400 Räsänen 2013 s 109-135.

401 Sandgren 2015 s 50-65.

${ }^{402}$ Bild se https://commons.wikimedia.org/w/index.php?title=Category:V\%C3\%A4ster\%C3\%

A5s_domkyrka\&filefrom=V\%C3\%A4ster\%C3\%A5s+Domkyrka+-+KMB+-+16001000254724. jpg\#/media/File:V\%C3\%A4ster\%C3\%A5s_Domkyrka_-_KMB_-_16001000256905.jpg.
} 


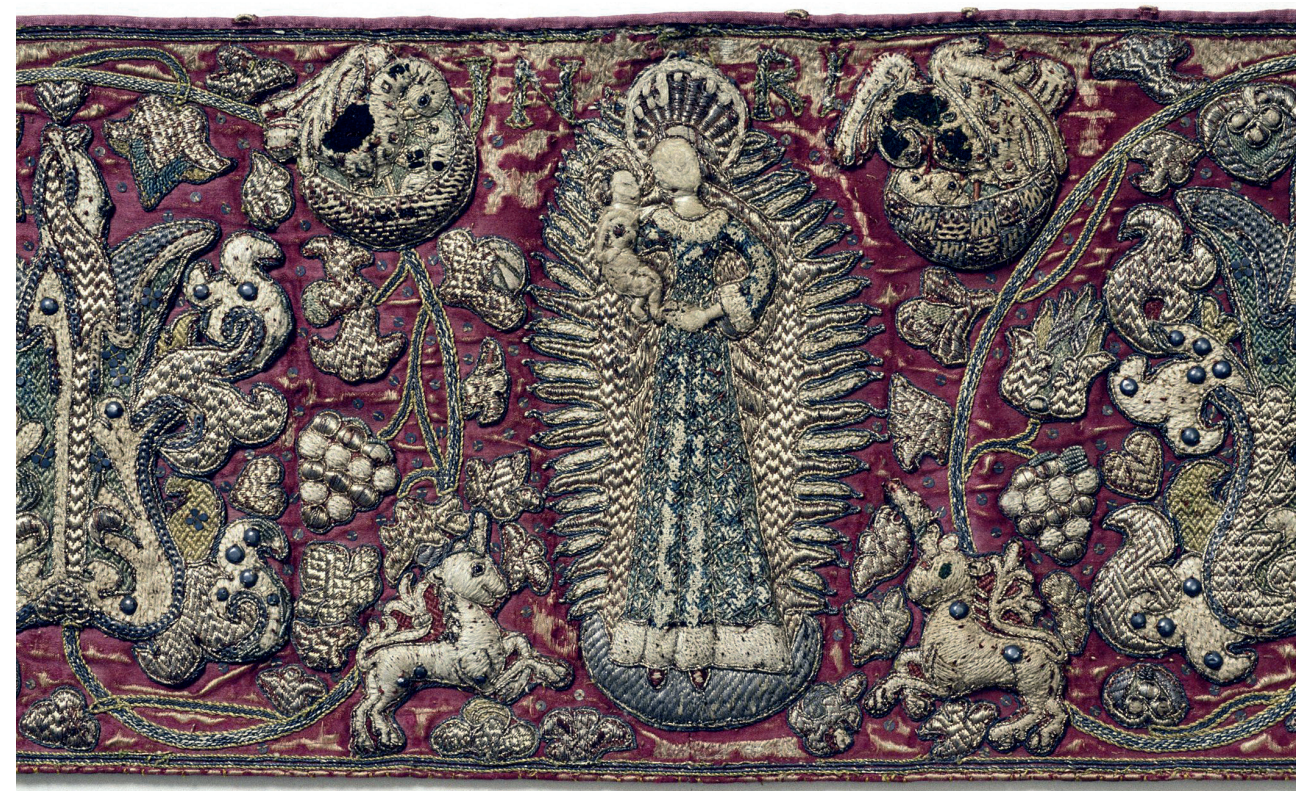

Bild 41. Altarbrunet frän Norrsunda (Uppl.) pryds av stora slingrande liljerankor och har en mittscen med den Apokalyptiska madonnan. Enhörningar och pelikaner flankerar Maria. Maria och djuren är utförda i relief, i läggsöm. Pärlor, ströningar och stenar har prytt broderiet. Broderiet har flyttats över till det nuvarande bottentyget på 1600-talet och kompletterats i vänstra sidan, samt kombinerats med antependium. Bilden visar en detalj med den centrala scenen. Höjd $25 \mathrm{~cm}$. Foto SHM.

Norrsunda kyrka (SHM 13647). (Bild 41.) Vinrankan, med eller utan druvor, är likaså en etablerad Kristussymbol som ses i flera altarbrun och på liturgiska dräkter, i kompositioner med Mariasymboler som stjärna och ros. Ros, stjärna och lilja är återkommande metaforer för Maria i Cantus sororums texter och de visuella anspelningarna på Maria genom dessa symboler kan fungera som en minnesteknik, och som en meditationshjälp i andaktslivet. Symbolkombinationerna blir, vart nunnorna än vände blicken, en ständig påminnelse om Marias och Kristi intimt förknippade roller i frälsningshistorien. Till detta kommer också broderimaterialen som anspelningar på framförallt Maria: pärlor, ädelstenar, bergkristall. Skärskådar man de Vadstenatillverkade broderierna upptäcker man snart att det har varit gott om sötvattenspärlor i dem, vilket även påverkat ljusreflexion och skuggning. ${ }^{403}$

Ibland är symbolerna utförda i detaljer som kräver närsynt granskning för att uppfattas av ögat, som de små vävda rosorna och m-initialerna i bandet kring mässhakekorset i Skara. (Bild 26.) Ett så närgånget betraktande var givetvis inte tillgängligt för nunnorna sedan de väl färdigställt de textila arbetena, föremålen övergick då till brödernas visuella nära kontext. Så länge det handlar om liturgiska föremål som ingick i nunnornas närmiljö, som läktaren, refektoriet, kapitelsalen eller klostergången, kunde de dock fortsätta ta del av det visuella budskapet. Att som i det tidigare diskuterade mässhakekorset från Skara inrama korsets IHS- och Maria-

403 Vadstenabroderier med ovanligt mycket pärlor kvar är mitrorna tillverkade för Västerås och Linköping, se Estham 1991 s 16-19, 24-25. 
monogram med ett blått band med gyllene m och rosor innebär ju att även heliga Birgitta inkluderas i den tydligt marianska kontexten. Rosorna kan nämligen syfta på både Maria och Birgitta. ${ }^{404}$ Även om systrarna inte längre kunde se det centimeterbreda bandets rosor när prästen bar mässhaken, kunde de uppfatta det som en del av den visuella och spirituella helheten. Det var ju de som hade vävt bandet.

I detta sammanhang kan det också vara värt att påminna sig om att de bilder som smyckade en medeltida kyrka och dess föremål inte enbart var till för det mänskliga ögats fröjd. Bilderna hade en viktig roll som delar av ett helhetskonstverk, de var en del av lovsången till Guds ära, precis som abboten Suger beskrev det redan under 1100-talet, i polemik mot Bernard av Clairvaux. ${ }^{405}$ Därför måste inte alla bilder synas för kyrkobesökarna, och därför finns det bilder som till och med är avsedda att "ses" enbart av det gudomliga, som högt placerade glasmålningar i katedralerna eller Bebådelsescenen på insidan av sakramentsskåpet från Alskog på Gotland. ${ }^{406}$

Medeltidens bildvärld kan ibland ge intryck av rädsla för tomrummet, horror vacui. Alla ytor fylls mer eller mindre av ornament i en oändlig variation, både inom arkitektur och bildkonst. Den här viljan att fylla bildytan präglar också många av föremålen som är tillverkade i Vadstena kloster. Istället för att uppfatta denna myllrande bildvärld som en rädsla för något, kan man vända på det och se den som en hyllning och en lovprisning till Skaparen, just i abbot Sugers anda. Genom att smycka lovsjungs Skaparen för det vackra i världen, och för förmågan att skapa detta till både människors och Skaparens glädje. Istället för att vara en distraktion så som Bernard av Clairvaux och som även heliga Birgitta varande för, kunde den istället vara en hjälp för det andliga livet både inom och utom klostermurarna.

Den medeltida spiritualiteten visade att i praktiken var bilderna - och därmed även de symboler som nunnorna använde - en hjälp för deras helgelse. Redan Isidor av Sevilla (c. 560-636) framförde tanken att en bild representerar ett objekt, och att man när man ser denna bild blir påmind om detta objekt. ${ }^{407}$ Det innebär en stark koppling mellan det avbildade och avbildningen. Det var många medeltida författare som var ytterst medvetna om bildernas positiva förmåga, inte minst de som hade nunnornas andliga liv i fokus. Man kan därför betrakta myllret av bilder, symboler, metaforer etc. i Vadstenamaterialet som ett andligt stöd, främst för de nunnor som levde där, eftersom det var de som skapade dem. Genom symbolerna och bilderna kunde de skapa sitt eget helgelsebefrämjande visuella referenssystem, och stundom med en uttalad birgittinsk vinkling. De utnyttjade naturligtvis inte bara den visuella resursen. Även andra sensorier som ljud och dofter var involverade i denna strategi. Melodierna och texterna i Cantus sororum, de övriga texterna och bildvärlden, alla

${ }^{404}$ En av de mer kända Birgittahymnerna inleds med orden Rosa rorans bonitatem, dvs. "Ros som idel godhet andas".

405 Om abbé Sugers idéer i Memoirs de la consécration de l'église Saint-Denis, se exempelvis André Moisans essä "Suger de Saint-Denis, Bernard de Clairvaux et la question de l'art sacré, ingår i Le beau et le laid au Moyen Age, CUER MA, Aix-en-Provence 2000 s 383-399. Fulltext: http://books.openedition.org/pup/4043.

406 Foto se http://www.orgelanders.se/Gotlandskyrkor/Alskog/skap1.jpg (20200313).

407 Se övers. av Isidor av Sevillas "De Pictura” i Laugerud, Ryan \& Skinnebach "Introduction” Materiality of Devotion 2015 s. 5. 
understödde varandra och kunde hjälpa till att hålla det andliga livets fokus hela tiden och överallt, vart de än vände blicken. Och även om nunnorna inte kunde se alla Mariareferenser på de liturgiska föremål som bröderna använde, så visste både systrarna som broderat dem och de som var sakristaner att referenserna fanns där, hela tiden. På detta vis är hela klostret, men framför allt kyrkorummet, ett andligt "Gesamtkunstwerk" skapat till Skaparens ära och nunnornas andliga väl.

\section{Visuella paralleller till andra nunnekloster}

Många klosterordnar är skapade som en reformreaktion mot de redan existerande, men visar att man ändå hämtade inspiration från föregångare. På samma sätt som cistercienserna var en reaktion mot sin samtid är heliga Birgittas ordensskapelse ett försök att reformera det depraverade klosterväsende som hon upplevde under 1300-talet, kanske främst under sina pilgrimsresor och sin långa vistelse i Italien. I många, främst sydeuropeiska, nunnekloster levde korsystrarna ett bekvämt liv med eget tjänstefolk och privata sviter, dvs. stick i stäv med fattigdomslöften och egendomsgemenskap som utgjorde fundament till alla klosterordnar. Man behöver emellertid inte resa särskilt långt längs pilgrimsvägarna på kontinenten för att se likheter och möjlig inspiration från kloster som står kvar än idag. Det är inte klarlagt vilka kloster som heliga Birgitta besökte under sina resor, men kanske fick hon inspiration till utformningen av nunnekronan från de nordtyska cistercienskloster, där en liknande nunnekrona var i bruk under 1300-talet? ${ }^{408}$ Kanske kunde det överdekorerade Wienhausens kloster skapa den form av motreaktion mot bilder som Birgitta företrädde? Kanske även läktarna på sådana platser som i nunneklostren Lüne, Lichtenthal, Altenberg eller Ebsdorf kan ha inspirerat hennes klosterplan, eftersom konstruktionerna där gjorde att nunnornas sång kunde höras väl $\mathrm{i}$ hela kyrkorummet, men utan att de själva syntes från lekmännens plats på kyrkgolvet. ${ }^{409}$ Det var också från de tyska områdena som det gick en reformrörelse inom dominikanerna under 1400-talet, en rörelse som påverkade det övriga monastiska livet långt utanför deras egna kloster. Texter översattes och spreds både inom och utom klostren. De svenska klostrens cura monialum, nunnornas andliga vård, påverkades i hög grad av aktörerna från det tysktalande området. Bland Vadstenahandskrifterna ser man verk av exempelvis Henrik Suso och Mechthild av Hackeborn, men också inhemskt tillkomna verk som texter av birgittinbrodern Jöns Budde i Nådendal och generalkonfessorn i Vadstena Nils Ragvaldssons översättning och förklaring till den svenska versionen av Cantus sororum, kallad Jungfru Marie örtagård (KB A 12). ${ }^{410}$

Den visuella kvarlåtenskapen från Vadstena kloster kan inte mäta sig med de bevarade skatterna från exempelvis de nyssnämnda Wienhausen, Lüne och Ebsdorf i Tyskland, men är som påpekades i kapitel 1 enastående för svenska förhållanden.

\footnotetext{
408 Krone und Schleier 2005 s 420-422, kat. nr. 326, fig. 326. Bilder ur Gisle Codex, se https:/quaternio.ch/faksimile-editionen/codex-gisle/.

409 Zimmer 1990 diskuterar nunneläktarens funktion i bl.a. Wienhausen och Lichtentahl.

410 Översatt och kommenterad av generalkonfessorn Nils Ragvaldsson, d. 1514.
} 
Från de andra svenska nunneklostren har vi nämligen bara fragmentariska upplysningar och ett fåtal identifierade föremål. Men, diskuterar man föremålen och deras användning i Vadstena bör man även beakta de kloster som grundades direkt från Vadstena. Där är det värt att söka efter paralleller och möjligheter till direktpåverkan från moderklostret, idéer som går att koppla tillbaka till Vadstena kloster. Som likaså nämndes i kapitel 1 hör Maribo i Danmark (1416) och Nådendal (1438) i nuvarande Finland till de viktigaste klosteretableringarna ur detta perspektiv, eftersom det var ett flitigt utbyte mellan moderhus och dotterkloster, både av såväl korrespondens, som av föremål och personer. Det var viktigt att sända ut sång- och skrivkunniga systrar och bröder för att lära upp de nya ordensmedlemmarna och utrusta de nya klostren med liturgiska böcker, klosterregel, andra föreskrifter och annat väsentligt redan från början. I praktiken innebar det att man spred skriftkonventioner till de nya skriptorierna. Materialet från Nådendal visar att man även förmedlade idéer för textiltillverkningen, både vad gäller teknik och formspråk. ${ }^{411}$ I Nådendalstextilierna ses samma symbolrikedom som i Vadstena med rosor, liljor, stjärnor, ek- och vinlöv. Där finns även Kristi sår och det sårade hjärtat, broderat på ett halslin. ${ }^{412}$ Det sårade hjärtat finns också på en av de få bevarade textilierna från Maribo, ett mässhakskors. ${ }^{413}$ Ett par Nådendalsbroderier ${ }^{414}$ (nu i Nationalmuseet Helsingfors) är översållade av Mariasymboler, livsträd och bokstäver, och har både Ave Maria-text och andra mer svårtolkade bokstäver. ${ }^{415}$ Till de ännu outredda ikonografiska inslagen på dessa båda föremål hör dubbelörnar med hjärta på bröstet samt det i samband med Dalhemstäcket nämnda bevingade hjärtat. ${ }^{416}$

Det fanns givetvis en variation mellan de olika klostren när det gäller antalet altaren utöver de av heliga Birgitta påbjudna. Jämfört med det ovanligt altarrika Vadstena hade både Nådendals och Maribo kloster färre lekmannaaltaren. ${ }^{417}$ Däremot finns det några bilder från dessa båda kyrkor som kan komplettera intrycket av

411 Walta diskuterar skrivare och biblioteket i Nådendals kloster i ”Birgittine Fragments in Finland: Reconstructing Naantali Abbey's Library", The Birgittine Experience, papers from the Birgittine Conference in Stockholm 2011, eds. Claes Gejrot, Mia Åkestam \& Roger Andersson, KVHAA, Konferenser 82, Stockholm 2013, s 11-29.

412 Bild hos Sandgren 2015.

413 Plathe, Sissel F., "Kristi sår og lidelses-redskaber gengivet med nål og tråd. Et Birgittinsk rygkors fra en messehagel i Maribo Domkirke." Stiftsbog og landemode-akt for Lolland-Falsters stift 2005, Nykøbing 2005 s 21-27, red. Helle Samson Heller. Även en mitra är bevarad från Maribo, se Norn 1948 s 63, fig. 30.

414 Båda broderierna har omarbetats kraftigt sedan de brukades under medeltiden, vilket gör dem svåra att rekonstruera.

415 Broderiet är omgjort och har en vertikal skarv. Övre radens bokstäver (versaler i läggsöm): L, $\mathrm{O}, \mathrm{A}, \mathrm{O} / \mathrm{G}$ ? Nedre raden (versaler \& gemener, ej läggsöm): b, I, a, r, 1/C? Det innebär att till vänster om skarven finns: L, O, b, I, a. Till höger finns: A, P/G, r, C.

416 Både det bevingade hjärtat och dubbelörnen betraktas i ikonografisk litteratur som 1700-talsfenomen.

417 Norn 1948 s 30 nämner tio kända altaren i Maribo, förutom de som stipuleras i klosterregeln. Databasen altartavler.dk listar likaså 10 dokumenterade altaren, http://asp.altertavler.dk/default. htm Antalet altaren i Nådendal är inte känt och nämns inte ö.h.t. i den senaste publikationen om klostret i Nådendal, Nådendal - Vallis Gratiae, Finlands Birgittakloster utg. av C. Cederbom, O. Ferm, S. Nyström, Runica et mediaevalia, Stockholm 2018. 
Vadstenakyrkans utrustning. Ett motiv som tidigare konstaterades saknas bland de många bilderna i Vadstena är Pietà, men en sådan skulptur har däremot bevarats i Nådendal. Från Maribo finns en S Augustinusskulptur kvar i sitt altarskåp, tydligt identifierbar. ${ }^{418}$ Han passar utmärkt väl in i den birgittinska kontexten eftersom Birgittas orden formellt sett grundades på Augustinusregeln, ${ }^{419}$ men något sådant lekmanna- eller klosteraltare är inte belagt i de skriftliga Vadstenakällorna. De åtta bevarade korstolarna från Mariager, Maribos dotterkloster, vittnar om att nunnorna omgavs av heraldik, Kristusbilder och Mariamotiv på sina stolar. ${ }^{420}$ (Bild 33.)

\section{Vadstenanunnornas konstkontakter}

En viktig aspekt av västerlandets klosterväsende är onekligen dess transnationalitet. Klosterordnar är inte nationella utan transnationella. Alla ordnar var spridda till många länder, inte bara grannländerna, så även Birgittinorden. För birgittinernas del innebar det att man förutom Nådendal och Maribo bland annat etablerade kloster i Florens (Paradiso), Bergen (Munkaliv) och via Maribo även det ovannämnda jylländska Mariager kloster. Den största medeltida ordensexpansionen skedde dock i de flandrisk-nederländska områdena, där det grundades ett tiotal birgittinkloster under 1400-talet. ${ }^{421}$

Samtidigt med ordensexpansionen i sydväst odlade man också viktiga kontakter söderut, genom de tyska dotterklostren i nordtyska områden och i Bayern. Både de nederländska och de tyska områdena märks i det visuella arvet från Vadstena kloster. Dels handlar det om den vid tiden så att säga normala importen av altarskåp och skulpturer från de stora tillverkningscentra som fanns i Nordtyskland och Flandern, dels om mindre föremål och mindre välkända importföden. Birgittaaltarskåpet som invigdes 1459 kom från Lübeck, liksom troligen Rosenkransaltarskåpet, ytterligare fem snidade altarbilder och eventuellt även det stora triumfkrucifixet. ${ }^{422}$ Åtminstone krucifixet var inom nunnornas siktlinje när de riktade blicken mot högaltaret. Det finns även bevarade broderier som kommer från tyskt område, vilka oftast är applicerade på dyrbara italienska sidentyger. ${ }^{423}$ Ibland har monteringen skett på broderiernas tillverkningsort, men ofta har de gjorts av nunnorna i Vadstena. För att

418 Bild S Augustinus, se http://asp.altertavler.dk/default.htm.

419 Rajamaa 1992 s 37.

${ }^{420}$ Ett av motiven är jungfru Marias möte med den uppståndne Kristus, ett birgittinskt motiv. Korstolarna står nu i den näraliggande Visborgs kyrka, Jylland, se t.ex. https://aalborgstift.dk/ stiftet/kirker?--fit_diocesedata-churchdb\%5B\%40 package $\% 5 \mathrm{D}=$ fit.diocesedata\&--fit_ diocesedata-churchdb $\% 5 \mathrm{~B} \% 40$ controller $\% 5 \mathrm{D}=$ church\&--fit_diocesedata-churchdb $\% 5 \mathrm{~B} \% 40$ action $\% 5 \mathrm{D}=$ show $\&$--fit_diocesedata-churchdb $\% 5 \mathrm{~B}$ church $\% 5 \mathrm{D} \% 5 \mathrm{~B}$ __identity $\% 5 \mathrm{D}=4 \mathrm{~d} 321 \mathrm{ef1}$ e22e-4971-83fc-7606e02d74c3 [access den 10 oktober 2019].

421 Se Sander Olsen mfl 2013 s 6-7 18-19, 101ff, 211ff. Expansionen österut i Europa var främst efter reformationen.

422 Andersson 1983 s 22, 26-32, 35-36. Triumfkrucifixets proveniens diskuteras av Tångeberg, Peter, Mittelalterliche Holzskulpturen und Altarschreine in Schweden: Studien zu Form, Material und Technik, Kungl. Vitterhets-, historie- och antikvitetsakad., Stockholm, 1986 s 145-147, 150.

423 Estham, Inger, "Medeltida textilier", Vadstena klosterkyrka, vol. 2 Inredning, Sveriges kyrkor vol. 194, red. Aron Andersson, Stockholm, 1983 s 112-118. 
systrarna överhuvudtaget skulle kunna tillverka all liturgisk paramenta krävdes givetvis att man kunde importera material. Framförallt gick det åt en hel del sidentyger och brodersilke, vanligtvis importerat från Italien. Det linne och ylle som behövdes kunde tillverkas av de egna resurserna. Sötvattenspärlor hade man likaså tillgång till från de älvar och sjöar klostret ägde eller hade fiskerättigheter i, medan så kallade ströningar (små silverbleck) etc. kunde beställas av lokala guldsmeder.

Det är känt att importen från Flandern till Sverige var betydande både när det gäller textilier och träskulpturer/altarskåp. Den enligt Vadstenadiariet vackert snidade Katarinabilden som invigdes 1489 har tyvärr gått förlorad, ${ }^{424}$ och av det flandriska högaltarskåp som invigdes 1521 återstår bara predellan med skulpturfragment. ${ }^{425}$ Däremot har både S Antonius och den så kallade sköna madonnan bevarats, som båda kommer från Bryssel. Till de textila importarbetena från Flandern hör broderierna på den så kallade Sturekåpans bräm och ryggsköld, ett mässhakskors med Johannes på Patmos och det stora figurbroderiet som visar en Kalvariescen, i litteraturen (missvisande) stundom benämnd Filippas gravtäcke. ${ }^{426}$ (Bild 42.) Kalvariescenen är dock ett typiskt exempel på hur ett importarbete, dvs. de broderade figurerna, monterats i klostret och vars bakgrund försetts med nunnornas broderade stjärnapplikationer. Ett exempel på konstim-

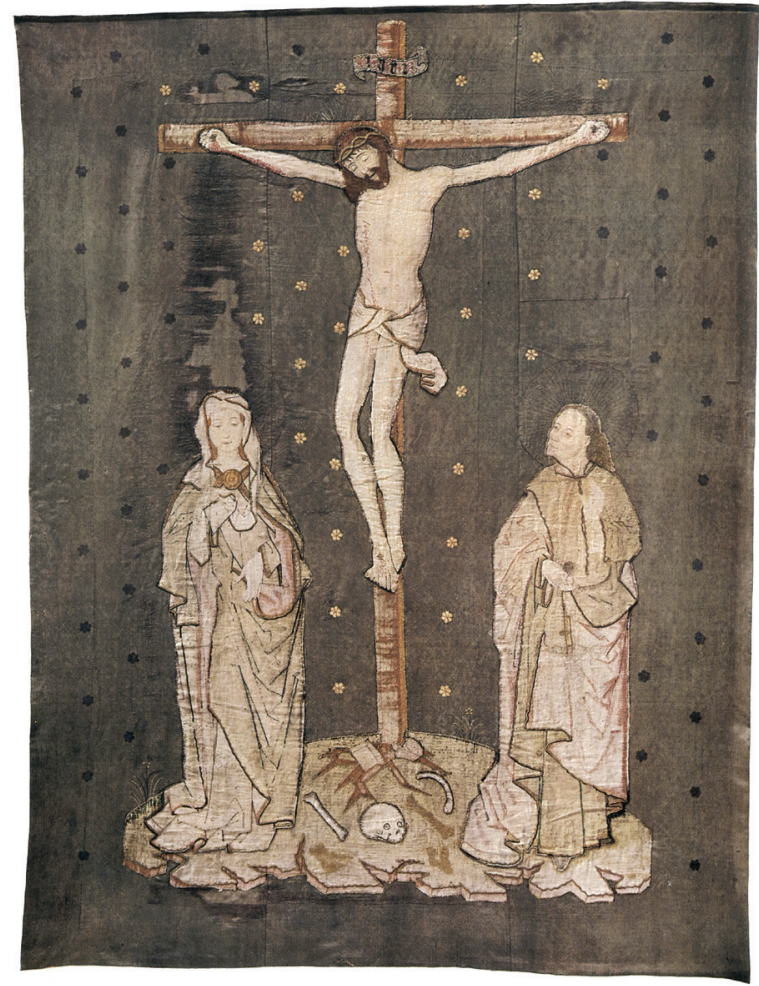

Bild 42. De stora broderade figurerna i Kalvariescenen är applicerade på ursprungligen blått siden. Även stjärnorna $i$ bakgrunden är utförda som applikationer, men av nunnorna $i$ klostret. Figurbroderiet är mycket slitet och man har vid konservering fyttat figurerna frän fram-till baksida samt flyttat om stjärnorna. Det skapat bestående märken i tyget som gör att man ser de forna konturerna samt mörkare fält där stjärnorna suttit tidigare. Mått 166,5 $\times 215 \mathrm{~cm}$. Vadstena klostermuseum. Foto ur Agnes Geijer och Andreas Lindblom Medeltida vävnader och broderier i Sverige 1928-29, plansch 179 sid XXX. port i mindre och billigare format än paramenta och skulpturer är de ovan nämnda tryckta miniatyrerna i Ingegerd Ambjörnsdotters bönbok (A 43). Bönboken innehåller bilder av såväl tysk som nederländsk/flandrisk härkomst. ${ }^{427}$ Även den tidigare nämnda Marie smärtorsbilden i bibelhandskriften A 1 visar på sydtyska kontakter och i synnerhet med tryckorten Nürnberg. (Bild 21.)

Förutom de importerade bilderna förefaller man ibland ha tagit intryck från andra områdens bildkonventioner. De inhemskt handmålade miniatyrerna som bevarats i

\footnotetext{
${ }^{42}$ DV 884.

425 Andersson 1983 s 89 fig. 89-90. Tillskrivs Jan Bormans verkstad av Aron Andersson. Invigning 6/9 1522 nämns i DV 1070.

${ }^{426}$ Det flandriska broderiet är för stort för gravstenen, saknar slitage på för gravstensbruket relevanta ställen samt avviker i kompositionen från hur ett gravtäcke utformades vid denna tid. Den har blivit blekt på ena sidan och man har flyttat över broderierna till "baksidan" vid senare tillfälle (troligen konservering).

427 Se Braaten 2006.
} 
handskrifterna är så få att det är svårt att dra några stilistiska slutsatser etc. om dem, men däremot finns det tillräckligt med marginaldekorer och dekorerade initialer för att göra vissa jämförelser. Lägger man därtill de inhemska textila verkens ornamentik blir tendenserna ännu tydligare. I både de textila arbetena och handskrifterna kan man spåra förbindelser med andra geografiska områdens traditioner. Nunnorna var uppenbarligen à jour med vad som var aktuellt på den internationella arenan.

De m-formade marginalstavarna i handskrifterna har redan nämnts, inspirerade av bokmåleri från Norge och klostret i Munkaliv (se avsnittet "M-rankor och hjärtan"). Deras placering i marginalerna visar sig sig ha sin textila motsvarighet i de nämnda smala band med gyllene $\mathrm{M}$ och rosor som kantar flera av de Vadstenatillverkade textilierna, bland annat mässhakekorset i Skara. I några norskt förknippade handskrifter finns inte bara de diskuterade $\mathrm{m}$-marginaldekorerna utan även initialer med smårutiga fonder. Sådana smårutiga initialfonder, förekommer inte för övrigt i Vadstenamaterialet. (Se bild 27, 30 ovan.) Riktas blicken ännu lite längre bort, mot det nederländska bokmåleriet, är stora initialer mot guldgrund, försedda med rejäla konkava urgröpningar i hörnen, tidstypiska under 1400-talet. I bönböckerna därifrån kan initialerna vara så stora att de dominerar boksidans textspegel. De stora guldinitialer som ses i Vadstenahandskrifter från decennierna närmast efter 1500 (t.ex. A 1, A 3 och A 12) är utförda i en jämförelsevis mindre skala, men innehåller samma element: näst intill kvadratisk grundform och tydliga hörnurgröpningar. Denna initialutformning påträffar man varken i det nordiska, tyska, franska, italienska eller engelska bokmåleriet.

I både det engelska och nederländska handskriftmaterialet kan man se ytterligare ett par motiv som återfinns i Vadstenas textilier och handskrifter: knutverksornamentik och påfågelsfjädrar. Knutverksornamentik förekommer på andra håll också, men företrädesvis tidigare i konsthistorien och inte i denna utformning under senmedeltiden. I det italienska bokmåleriet uppträder det ännu under 1300-talet, och det finns birgittinskt näraliggande exempel i de prakthandskrifter av heliga Birgittas Uppenbarelser som tillverkades i Neapel på 1380-talet. ${ }^{428}$

Kombinationen av knutverksornament och påfågelspennor är ett upprepat inslag $\mathrm{i}$ åtminstone delar av det engelska bokmåleriet under 1400-talet. Den broderade relikasken i Linköpings domkyrkomuseum har också denna sammanställning av knutornament och påfågelsfjädrar på kuppa respektive lock. ${ }^{429}$ I Vadstena har nunnorna förenklat påfågelns vingpenna till en mer granbarrsliknande gren och "ögat" på vingpennan har ofta försvunnit. Ytterligare ett stildrag, som förefaller komma från engelskt bokmåleri, är de slanka sammankopplade marginalstavarna. Dessa raka marginalstavar kopplar ihop filigraninitialerna i samma spalt med varandra, som i A 3 och den engelsktillverkade bönboken A 82a. Ibland finns samma sammankopplande tendenser i det italienska bokmåleriet från 1400-talet, men parallellen mellan det engelska och Vadstenamåleriet är tydligare. Det är även i det engelska

428 De antikiserande knutornament som förekommer i den italienska renässanskonsten har en helt annan karaktär.

429 Sandgren, Eva Lq, Wahlberg, Ingela, ”Det broderade relikvariet i Linköpings domkyrka”, Fornvännen 2018 (112):4, Stockholm 2018 s 184-195. 
bokmåleriet som man under 1400-talet finner marginalstavar som breder ut sig horisontellt på samma sätt som i bibelhandskriften KB A 1 (f. 190v, 242v). ${ }^{430}$ Kontakterna mellan England och Sverige går givetvis främst via Syon Abbey i London, men det var sannolikt inte så mycket som producerades inom det engelska klostrets egna skriptorier. Därför är det är troligen inte de olika klostermedlemmarna som stått i inspirerande kontakt med varandra. Snarare har de handskrifter som man använde i Syon Abbey gett inspiration till Vadstenafolket genom de frekventa kontakterna mellan klostren. Det viktiga med inspirationskällan är att Vadstena assimilerade idéer från detta håll, inte att det var handskrifter gjorda av birgittinerna själva.

En något mer problematisk kontakt- och inspirationsväg är den med det italienska bokmåleriet. Som nämndes nyss finns vissa inslag av både knutverksornament och sammankopplade marginalstavar där, men inte riktigt samtidigt och inte så sent som i Vadstena. Till viss del ser det också ut som de stora påkostade initialerna i det sena napolitanska 1300-talsmåleriet skulle ha kunnat påverka en del av Vadstenahandskrifternas initialer under tidigt 1500-tal. ${ }^{431}$ De stora akantusbladen och vissa liljeformer ligger stilistiskt nära varandra. En enkel, men tyvärr mindre trolig förklaring kunde vara att systrarna i skriptoriet hade tillgång till den normerande prakthandskrift av Uppenbarelserna som klostret ägde, trots att den bara förevisades mycket sparsamt. ${ }^{432}$ Frågan är också om man var lika förlagestyrd när det gäller bokmåleriet som när det gällde själva texttraderingen? Dekoren hade ju ingen juridisk eller ens normerande relevans. Den var dessutom skapad efter heliga Birgittas egen tid, helt oberoende av hennes inflytande. (Hon gjorde sannolikt inga anvisningar för den konstnärliga utformningen av uppenbarelseshandskrifterna.) En tidigare oprövad tanke är att det exemplar av Uppenbarelserna som kallas Ericsbergshandskriften (A 72a), ${ }^{43}$ tillhörde Vadstenaklostret under medeltiden och möjligen fungerade som kopieringsexemplar i skriptoriet, åtminstone omkring sekelskiftet 1500. Handskriften var då lite mer än etthundra år gammal. Den kan dock inte ha varit identisk med den nyssnämnda prakthandskrift som man vid enstaka tillfällen i klostrets historia refererar till. Ericsbergshandskriften har tvärtom egenskaper som utmärker en handskriftsförlaga som är till för att kopieras och mångfaldigas: den är gjord på papper, varje lägg har ett yttre ark av pergament som skydd, miniatyrerna är kolorerade skisser, det finns inga förgyllningar och den innehåller dessutom en del fel. ${ }^{434}$ Den visar dessutom upp ett franskt bokmåleri i kombination

\footnotetext{
430 Se https://www.manuscripta.se/ms/100201.

${ }^{431}$ Se bildmaterialet i Aili, Hans \& Svanberg, Jan, Imagines Sanctae Birgittae, KVHAA, Almqvist \& Wiksell International, Stockholm 2003.

${ }^{432}$ Undhagen, Carl-Gustaf, "Vadstena klosters förlorade praktexemplar av Birgittas revelationer", Heliga Birgittas uppenbarelser 650 år: en jubileumsutställning av latinska handskrifter och editioner tryckta 1492-1992, red. Carl-Gustaf Undhagen, Fredrik Vahlquist, Univ.-bibl., Lund 1995, s 15-20.

${ }^{433}$ En kort presentation av handskriften ges på http://www.kb.se/english/collections/manuscripts/ older/ericsberg/. Den har nämnts i Lindgren, Mereth Bilden av Birgitta, Wiken, Höganäs 2002 (1991) och Nordenfalk, Carl, "Saint Bridget of Sweden as represented in illuminated manuscripts", De artibus opuscula XL: essays in honor of Erwin Panofsky vol. 1, New York Univ. Press, New York 1961.

${ }^{434}$ Den har ännu inte undersökts ingående kodikologiskt.
} 
med italiensk skrift, vilket förekom i Avignon och i det franskpåverkade napolitanska riket under 1300-talet. Utförandet tyder på att den skulle ha kunnat fungera som underlag för såväl prakthandskrifterna som de senare kopior som utfördes för de nygrundade dotterklostren. Tyvärr finns det ingen känd dokumentation om den innan den påträffades i biblioteket på Ericsbergs slott i början av 1960-talet. ${ }^{435}$

Ytterligare frågor kring influensernas olika vägar reser å ena sidan avsaknaden på stilinfluenser från det tyska bokmåleriet och å andra sidan de svenska influenserna i det italienska klostret i Florens, Paradiso. Sydtyskland hade en väl utformad egen praxis i hur marginalslingor och initialer utformades och det finns exempel på det i Vadstenamaterialet, men då handlar det om importerade verk. Exempelvis den typ av akantusrankor som förekommer i Bayern, där det fanns birgittinkloster, ses inte alls i det som bevarats från Vadstena kloster. I det textila arvet består de tyska inslagen som sagt främst av importerade färdiga broderier som monterats i klostret, men inget har bevarats som kan jämföras med de vitbroderier och tapeter som finns från exempelvis klostren kring Lüneburgerheden. ${ }^{436}$

Klostret Paradiso i Florens grundades redan på 1390-talet och hör därmed till de allra första dotterklostren inom birgittinorden. Florens hade i allra högsta grad en etablerad konstnärlig tradition av hög klass vid denna tid, där även bokmåleri ingick. I staden fanns flera framstående kloster och sekulära verkstäder som producerade illuminerade handskrifter, särskilt under 1400-talet. Den amerikanska bokhistorikern Melissa Moreton har konstaterat att Paradisohandskrifternas layout avviker från den dåtida gängse italienska. ${ }^{437}$ Däremot ser handskrifterna ut som om de kom från Nordeuropa, eller till och med som om de kom från Sverige. För att tillverka sådana handskrifter bör det ha funnits skrivare/skriverskor som förde med sig handskriftskonventionerna från Sverige och lyckades implementera dem i den italienska miljön, trots den etablerade lokala bokmåleritraditionen.

Det verkar alltså som om Vadstena kloster i några situationer har påverkat andra klosters traditioner, och i andra lägen låtit sig inspireras av dem. Det är inte så förvånande att man i Vadstena uppskattade de m-formade marginaldekorerna från Norge och nyttjade dem som en Mariareferens. Även påfågelsfjädrarna hör till den övertagbara symbolvärlden genom sina referenser till uppståndelsen. Bevekelsegrunderna för införlivandet av de sammanlänkade engelska marginalstavarna och de fyrkantiga initialfondernas djupa urgröpningar från det nederländska bokmåleriet får förbli oklara tills vidare.

Den bokliga kulturen utvecklades jämförelsevis sent i Sverige. ${ }^{438}$ En konsekvens av detta skulle kunna vara en påverkbarhet eller valfrihet, där man i Vadstena as-

${ }^{435}$ Lindgren och Nordenfalk har gjort sinsemellan olika tolkningar av handskriften utifrån stilistiska kriterier och menar att den tillverkats i Sydtyskland, antingen vid konsiliet i Konstanz 1414-18 eller konsiliet i Basel/Ferrara/Florens 1431-49. Nordenfalk 1961 s 371-93, Lindgren 2002 s 14-15, se även Svanberg \& Aili 2003 vol. 2 s 109. Ingen av dessa författare tar hänsyn till kodikologin.

${ }^{436}$ Kvinnoklostren i Wienhausen, Ebsdorf, Lüne exempelvis.

${ }^{437}$ Moreton, Melissa N. "Scritto di bellissima lettera": Nuns' book production in fifteenth and sixteenth-century Italy, otryckt PhD thesis. University of Iowa, Iowa City, Iowa 2013.

${ }^{438}$ Sandgren, Eva Lq"Nordeuropa", Beier, Christine (red.) Geschichte der Buchkultur, Band 5 Gotik 
similerar delar av det som man möter från Norge, England och de nederländska områdena. I det vadstenensiska handskriftsmaterialet går det att identifiera norskengelska 1200-talsdrag, engelska drag från första delen av 1400-talet och nederländska drag från det senare 1400-talet. Tyvärr gör bevarandesituationen det svårt att bedöma huruvida Munkaliv, Maribo och Mariager även assimilerade influenser från Vadstena, men däremot är kopplingen till Nådendal stark inom både textil- och handskriftsproduktion.

De svensk-nordiska konstnärliga förhållandena står i kontrast till Italien och södra Tyskland, där det sedan århundraden tillbaka fanns regionala och till och med lokala traditioner för bokmåleri. När de sydtyska birgittinklostrens boktillverkning inleddes fanns det därför etablerade traditioner att arbeta inom, både vad gäller bokmåleri och böckernas utformning. Även om klostret Altomünster ombildades från benediktinkloster till birgittinkloster först 1488, hade det en skriptorietradition med rötter i 700-talet. Gnadenberg grundades ca 1420 av folk från både Maribo och Paradiso, och även där fortsatte man i den regionala sydtyska stilen när man tillverkade böcker under 1400-talet. I Paradisoklostret (1394) har man märkligt nog däremot inte gått helt samma väg, även om det finns klart lokala, dvs. florentinska, stildrag i en del av Paradisohandskrifterna. Generellt sett har man istället profilerat sig gentemot den inhemska skriptorietraditionen, och avviker inte bara från det italienska utan även från det lokala florentinska bokmåleriet. Detta strategival har ännu ingen förklaring, men man kan fundera på i vilken grad som direktutsända systrar från Vadstena har påverkat utvecklingen. Tyvärr är väldigt lite känt om kontakterna mellan Vadstena och Paradiso när det gäller just nunnorna. Det råder dock inget tvivel om att Vadstenafolket måste ha skickat nunnor till Paradiso för att etablera klostret, men det är bröderna som nämns i dokumenten. Paradisoklostret är tyvärr fortfarande relativt outforskat. ${ }^{439}$

\section{Ett avgränsat rum men inte en begränsad värld}

Den klausur som Vadstenanunnorna levde i innebar i allra högsta grad en avgränsning av deras geografiska sfär. Trots den fysiska begränsningen var det ett livsrum som i hög grad tog intryck av världen utanför murarna. Hit innanför murarna nådde inte bara det senaste inom den andliga fostran som nunnornas biktfäder förmedlade till sina adepter (cura monialum), utan också den visuella gestaltning som ibland förknippades med dessa idéer. Förutom helgonbilder som ackompanjerar och illustrerar de olika helgonbönerna i bönböckerna finns också bilder som har andra funktioner än rent illustrerande. Som vi sett ovan var många bönboksbilder förknippade med avlater. I några av de bevarade avlatsbreven beskrivs de andaktsövningar som skulle utföras inför bilderna. Många gånger var det frågan om att be änglahälsningen, Ave

2, Akademische Druck- u. Verlagsanstalt, Graz 2018, s 9-12 (42).

${ }^{439}$ I Sara Ekwalls efterlämnade handlingar på UUB finns opublicerat material om Paradisoklostret. Höijer 1905 är kortfattad om Paradisoklostret och nämner inte nunnorna i sin översikt över Birgittinordens tidiga historia. 
Maria, dvs. något som de flesta lärt sig redan som barn. Vissa övningar praktiserades enskilt, kanske i klostergången eller den egna cellen, medan andra utfördes i det kollektiva utrymmet på nunneläktaren. Ett sådant gemensamt exempel är det tidigare nämnda knäfallet inför bilden av "Kristus dignar under korset" som påbjöds i samband med fredagens Botpsalmsprocession. Som exempelvis Tanja KohwagnerNikolai och Laura K. Skinnebach varit inne på kan och bör man se tillverkningen av föremålen, i detta fall både de textila och handskrifterna, som en materialisering av bönen och en andaktsövning i sig. ${ }^{440}$ Då blir Vadstenanunnornas bruk av andliga referenser ända ned på stygnnivå i sig en visuell och materiell bön och del av ett internt referensstärkande system i cura monialum. Därmed inte sagt att de ägnade sig aktivt åt enskild bön i det gemensamma arbetsrummet, eftersom man under arbetstimmarna där ägnade sig åt bland annat högläsning ur uppbyggelselitteratur.

Det löper två parallella visuella spår i nunnornas handskrifter och textila produktion. Den ena är de identifierbara scener som avbildas och det andra är symbolerna som vävs in i dekoren. Genomgången visar att trots att bönböckerna har begränsade figurativa bildprogram bär de en birgittinsk prägel. Många av textilierna är också präglade av sin ordenskontext. Det är emellertid inte frågan om att framställa den heliga Birgitta eller andra centrala ordensgestalter, utan det är scener som relaterar till Uppenbarelsernas centrala teologiska ståndpunkter eller som genom sin sammansättning pekar i samma riktning. Tillsammans bildar de inte bara en fysisk bildförsedd kontext utan också en immateriell enhet, ett birgittinskt kosmos som omsluter nunnorna.

I både handskriftsdekor och på de liturgiska textiliernas vävda band finns anspelningar på jungfru Maria genom marginalrankorna med m-formade bågar och de vävda gyllene M-en. På broderier och i marginaldekorer framställs påfågelsfjädrar som påminnelse om hoppet om uppståndelsen. Hjärtan fungerar som en referens till Kristi och Marias ömsesidiga och självutgivande kärlek i marginalrankor och som broderat läggsömsmönster på Marias klänning eller i hennes närmaste omgivning. En komprimerad visuell version av denna dubbla kärlek är de dubbelhjärtan som nunnorna i Nådendal broderade. Bilden av det sårade hjärtat i bönboken C 443 (bild 22b) fungerar som en andakts/meditationsbild på samma sätt som den komprimerade varianten i de nådendalska dubbelhjärtana. Det viktiga är inte vilkendera av Jesus eller Maria som så att säga kommer först, utan att det finns ett ömsesidigt beroende mellan dem och i deras frälsningshistoriska betydelse. Jungfru Marias frälsningshistoriska kärleksroll framträder således från det stora till det lilla formatet. Hennes smärta vid sonens död framställs som ett svärd genom hjärtat, i enlighet med Simeons profetia i Lukas 2:35. Detta motiv, Compassio Mariae, finns på flera föremål. Hennes lidande är inkluderat i bönböckernas meditationsbilder med det sårade hjärtat och hennes hjärta är ett av de båda i dubbelhjärtana. Det diskuterade Dalhemstäcket (SHM 23022:26) visade sig också innehålla ett flertal marianska referenser, förutom de birgittinska. (Bild 40.)

${ }^{440}$ Kohwagner-Nikolai, Tanja, "Per manus sororum-": niedersächsische Bildstickereien im Klosterstich (1300-1583), München, 2006, Skinnebach, Laura K. Practices of perception - Devotion and the senses in Late Medieval Northern Europe, diss. Bergen 2013. 


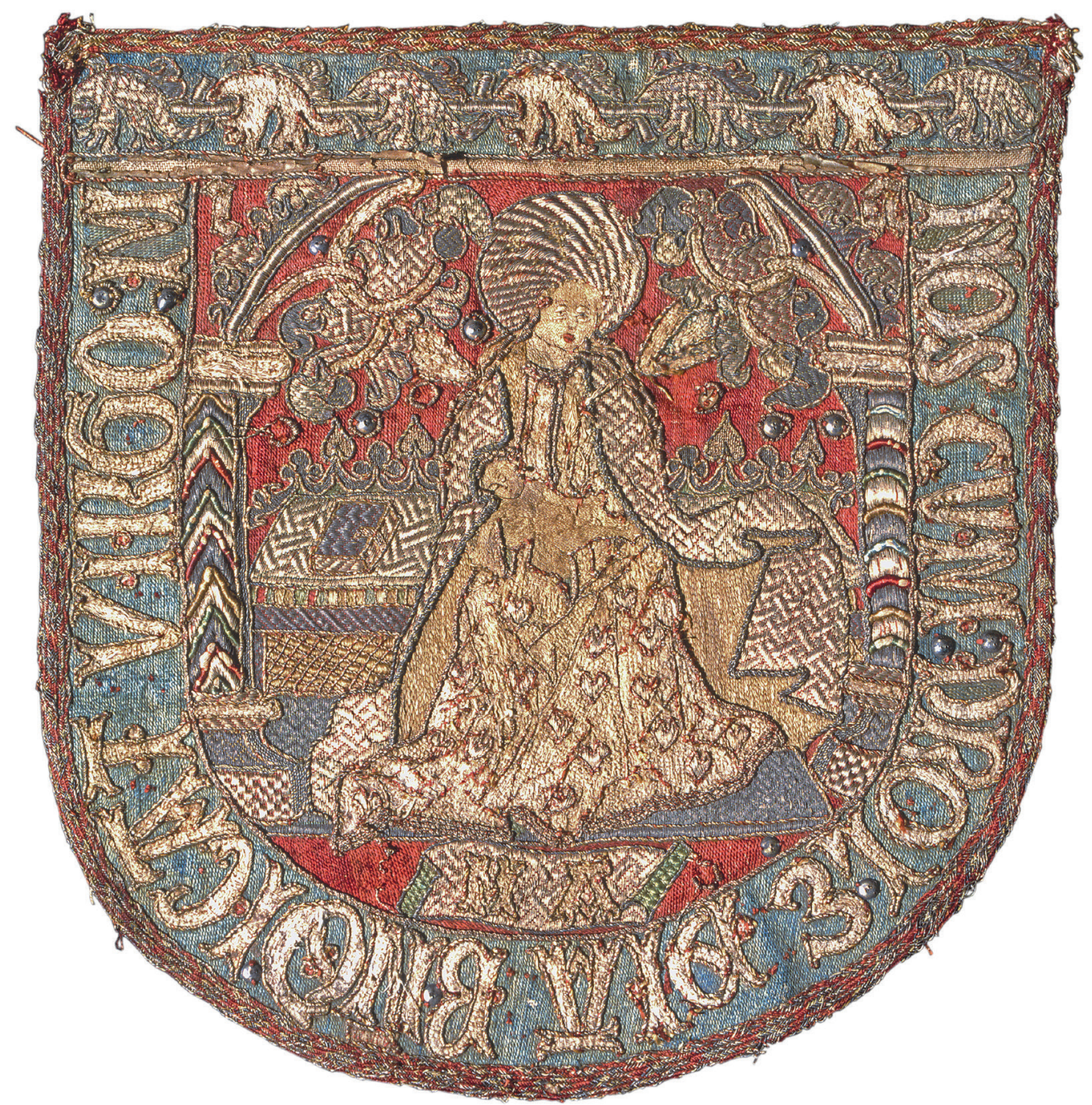

Bild 43. Broderad ryggsköld till korkåpa. Den tronande Maria med Jesusbarnet inramas av en text ur den birgittinska liturgin. På bennes klänning är små hjärtan broderade, och på bänkens rygg och bönbokens pärmar återkommer hjärtformerna. Under Maria står MA på ett språkband och i svicklarna på ömse sidor om hennes huvud ses initialerna i och a. Broderiet är utfört i läggsöm och yttäckande klyvsöm. De vita partierna har täckts av vita sötvattenspärlor. Mått ca $31 \times 31 \mathrm{~cm}$. Inv. nr 1502, (C) Västergötlands länsmuseum.

Även i de små och dekorativa detaljerna återfinns anspelningarna på Marias kärlek, framställda som exempelvis hjärtformade hängen på initialer i bönböckerna, som bakgrundsmönster till skildringen av hennes himmelska upptagning på den broderade bården i Skara, i mönsterformen på läggsömmen i hennes klänning på liljealtarbrunet i Vadstena eller de broderade hjärtana på hennes pärltäckta klänning i ryggskölden i Skara. (Bild 27, 38, 39, 43.) Genom att placera mönsterformerna på "rätt" ställe ges de en ytterligare dimension förutom den rent dekorativa. ${ }^{441}$ Detta

${ }^{441}$ Hjärtformad läggsöm förekommer huvudsakligen i samband med framställningar av jungfru Maria. 
var givetvis de broderande och illuminerande nunnorna medvetna om, eftersom de skapade dem, och därigenom formade de ett marianskt genomsyrat kosmos i birgittinsk version. Här spelar också den tidigare nämnda medeltida synen på bilder in: det viktigaste var inte att det mänskliga ögat alltid kunde uppfatta allt, utan bilderna hade en funktion i sig, även utan en perceptionsmedveten åskådare. Samtidigt som de lovsjunger Skaparen genom sin existens kan de dessutom påverka betraktaren. Bilderna har verkanskraft och existensberättigande i sig själva, tillverkade till Guds ära.

Böckerna som systrarna skapat behöll de huvudsakligen i sitt konvent. De var specialtillverkade för att användas i deras egen interna krets, och som vi sett fyllda av både birgittinska referenser och allmänkatolska motiv. Detta var deras närmaste bildkontext på det viset att de bar med sig bilderna i böckerna och hade dem framför sig i knäet i koret. Där samsades helgonbilder och passionsmotiv med minivarianter av anspelningar på Kristi och Marias kärlek i form av hjärtformade marginalhängen och m-formade marginalrankor. När systrarna lyfte blicken mot altaret såg de mot Kristus, i monstransens hostia. Altarets framsida pryddes av altarbrunet (bild 34), med text ur Cantus sororum och den scen med det i Birgittas uppenbarelser skildrade mötet mellan den uppståndne Kristus och jungfru Maria. Bortom andaktsaltaret såg nunnorna vidare mot stenskulpturen av jungfru Maria på hennes altare i öster och möjligen även heliga Birgittas skrin. Nedanför, mellan nunneläktaren och Mariakoret, kunde de ana det specialkomponerade Birgittaaltarskåpet på klostergrunderskans eget altare. Utmed den västra sidan av nunneläktaren satt de femton passionstavlorna, likaså de med en birgittinsk prägel genom motivvalen. I en vidare krets runt omkring nunnorna fanns sedan bilder som hörde till den vanliga katolska bildvärlden - triumfkrucifixet, den hängande Mariabilden i taket, apostlarnas altaren, martyrer och helgon i mängd, i många fall placerade utom systrarnas synhåll, men tillgängliga för kyrkans besökare. På så vis bestod systrarnas sfär både av den allmänkyrkliga och en specifikt birgittinsk bildvärld.

Nunnornas bildvärld hade uppenbarligen flera funktioner. Det mest uppenbara är att de kunde vara meditationsbilder, som frontespiserna i bönböckerna, men de kunde även vara direkta illustrationer till de vidstående texterna, som exempelvis vid helgonböner. Betraktar man föremålen närmare, både böcker och textilier, så finns emellertid än fler betydelselager som ger ytterligare dimensioner till de rent figurativa eller emblematiska framställningarna. Referenserna till jungfru Maria, Kristus, heliga Birgitta genomsyrar ornamentiken ned på stygnnivå och ut i marginalrankorna. Stjärnor, rosor, liljor, paradisträd, vinrankor, bokstäver och pärlor kan fungera både som påminnelse för den okoncentrerade och fördjupande för den bedjande nunnan. De skapar ett universum där bilderna är avsedda att hjälpa nunnorna att rikta sina tankar åt rätt håll för att be. På så vis är de i överensstämmelse med heliga Birgittas intentioner att bilderna inte skall distrahera klosterfolket från deras viktigaste uppgift, bön.

Många av de textila föremål som nunnorna tillverkat lämnade snart deras egen del av klostret för att istället användas av bröderna, dvs. de liturgiska textilierna, paramentan. De liturgiska textilierna var i hög grad bildbärande föremål. Det är nu 
dags att följa med dessa textila föremål över till brödernas del av kyrkan. Därmed flyttas betraktarperspektivet över till brödernas kor i väster, och den bildvärld som de hanterade och omgavs av i klosterkyrkan. 